\title{
Saying 'l': Women, Desire and Their Depiction in East Germany
}

by

Jane Freeland, B.A.

A research essay submitted to the Faculty of Graduate Studies and Research

in partial fulfilment of the

requirements for the degree of

Master of Arts

Institute of European, Russian and Eurasian Studies

Carleton University

Ottawa, Ontario

June, 2010

(๑) 2010, J. Freeland 
Library and Archives
Canada

Published Heritage

Branch

395 Wellington Street

Ottawa ON K1A ON4

Canada
Bibliotheque et

Archives Canada

Direction du

Patrimoine de l'édition

395, rue Wellington

Ottawa ON K1A ON4

Canada
Your file Votre référence

ISBN: 978-0-494-71676-2

Our file Notre référence

ISBN: 978-0-494-71676-2
NOTICE:

The author has granted a nonexclusive license allowing Library and Archives Canada to reproduce, publish, archive, preserve, conserve, communicate to the public by telecommunication or on the Internet, loan, distribute and sell theses worldwide, for commercial or noncommercial purposes, in microform, paper, electronic and/or any other formats.

The author retains copyright ownership and moral rights in this thesis. Neither the thesis nor substantial extracts from it may be printed or otherwise reproduced without the author's permission.
AVIS:

L'auteur a accordé une licence non exclusive permettant à la Bibliothèque et Archives Canada de reproduire, publier, archiver, sauvegarder, conserver, transmettre au public par télécommunication ou par l'Internet, prêter, distribuer et vendre des thèses partout dans le monde, à des fins commerciales ou autres, sur support microforme, papier, électronique et/ou autres formats.

L'auteur conserve la propriété du droit d'auteur et des droits moraux qui protège cette thèse. $\mathrm{Ni}$ la thèse ni des extraits substantiels de celle-ci ne doivent être imprimés ou autrement reproduits sans son autorisation.
In compliance with the Canadian Privacy Act some supporting forms may have been removed from this thesis.

While these forms may be included in the document page count, their removal does not represent any loss of content from the thesis.
Conformément à la loi canadienne sur la protection de la vie privée, quelques formulaires secondaires ont été enlevés de cette thèse.

Bien que ces formulaires aient inclus dans la pagination, il n'y aura aucun contenu manquant. 


\begin{abstract}
This thesis analyses how women's desire gained expression in East Germany, either sexually or materially, and how the regulation of these desires was depicted in East German popular culture, particularly cinema from the fifties to the early seventies. In doing so it traces the evolution from the 1950s when depictions of desire emphasised the importance of socialist values for women to the early seventies, when desire was used by filmmakers to comment on the failure of the state to tolerate the protagonist's quest for self-fulfillment. Contextualised within the social and political developments from this era, this thesis explores how women's desires were essential to establishing a dialogue opposed to the regime, as exemplified in the films Der Dritte (Her Third, 1972) by Egon Günther and Die Legende von Paul und Paula (The Legend of Paul and Paula, 1973) from Heiner Carow.
\end{abstract}




\section{Acknowledgements}

I would like to acknowledge the assistance of the Centre for European Studies at Carleton University and the DEFA Library at the University of Massachusetts-Amherst for their support of my research. Deepest gratitude also goes to my supervisor Dr. Jennifer Evans for her guidance in my research.

Thanks also goes to my parents, without whom I would not be here. Specifically, to my mother, Lesley, thank you for your patience and always pragmatic advice, and to my father, Richard, thank you for your excellent proof-reading, I know I can count on you, even though you disagree with my use of the word 'however'. 


\section{Table of Contents}

$\begin{array}{ll}\text { Abstract } & \text { ii }\end{array}$

$\begin{array}{ll}\text { Acknowledgements } & \text { iii }\end{array}$

Glossary of German Terms and Abbreviations $\quad$ v

$\begin{array}{lc}\text { Introduction } & 1\end{array}$

$\begin{array}{ll}\text { Equality - Without Masculinisation } & 17\end{array}$

The Difficulty of Saying 'I'

Ideal and Reality Never Go Together 83

$\begin{array}{lr}\text { Conclusion } & 130\end{array}$

$\begin{array}{lr}\text { Bibliography } & 139\end{array}$ 


\section{Glossary of German Terms and Abbreviations}

Deutsche Film-Aktiengesellschaft (DEFA): German Film Corporation.

DEFA-Kommission: A body formed to coordinate between DEFA and the SED Central Committee on personnel matters.

Demokratischer Frauenbund Deutschlands (DFD): Democratic Women's League of Germany.

Diakonissenheim: A convent school.

Der Dritte: "Her Third," directed by Egon Günther, released 1972.

Ernst Thälmann Pioniere: Ernst Thälmann Pioneers, a socialist group for young children.

Das Fahrrad: "The Bicycle," directed by Evelyn Schmidt, released in 1981.

Frauenfilme: Gegenwartsfilme that featured female protagonists and female centred storylines.

Frauenschicksale: “The Destinies of Women,” directed by Slatan Dudow, released 1952.

Frauenpolitik: Women's policies.

Die Frau und der Sozialismus: "Woman Under Socialism," August Bebel's seminal text on women's roles under socialism.

Freie Deutsche Jugend (FDJ): Free German Youth, a socialist youth group for teenagers and young adults.

Gegenwartsfilme: Contemporary screen dramas or social dramas, set in the present day of the GDR.

Kahlschlag: The colloquial term for the events of the 1965 Eleventh Plenum that saw severe censorship of DEFA productions.

Kommunistische Partei Deutschlands (KPD): Communist Party of Germany.

Die Legende von Paul und Paula/'Die Legende': The Legend of Paul and Paula, directed by Heiner Carow, released 1973.

Nachdenken über Christa T.: "The Quest for Christa T," written by Christa Wolf, published 1968. 
Neubau(ten): The massive apartments built during the seventies and eighties as a result of the 1971 Five-Year Plan.

Neues Deutschland: "New Germany," the SED Party newspaper.

Staatssicherheitsdienst or Stasi: State security service.

Sozialistische Einheitspartei Deutschlands (SED): Socialist Unity Party.

Sozialistische Persönlichkeit: Socialist Personality.

Utopieverlust: Loss of utopia, an aesthetic of mourning used by East German artists beginning in the sixties.

Verwirrung der Liebe: “Love's Confusions," directed by Slatan Dudow, released 1959. 


\section{Introduction}

In the German Democratic Republic the emancipation of women has been achieved (Lange, 1987: 76) ${ }^{1}$

Between 1949 and 1990 Germany was divided - split between East and West, between socialism and capitalism. Daily life in the two Germanys proceeded quite differently, from the brand of coffee drunk in the morning to the television programs viewed at night. Much has been written on the everyday life and experience of socialism and dictatorship in the German Democratic Republic (GDR) and attempts have been made by historians to classify and determine not only what kind of dictatorship the GDR represented, but also the extent to which the authoritarian branches of the state influenced the daily lives of East Germans (Jarausch, 1999). ${ }^{2}$ Within the context of German reunification, debate on the question of East Germany has often split between those who emphasise the totalitarian aspects of the regime of the Sozialistische Einheitspartei Deutschlands (Socialist Unity Party, SED) and those who empathise with the ideals of the socialist project and claim the GDR as a "failed experiment" (Ibid: 4). There are those still who claim the GDR as little more than a "footnote in world history" (Hans-Ulrich Wehler qtd in Harsch, 2010: 9).

Writing in 1997 historian Konrad Jarausch called for a more nuanced approach to East German history, one that respects the "contradictions of the GDR experience so as to recover the various shades of gray, characteristic even of life under a dictatorship" (1997: 5). This thesis aims at contributing to this differentiated approach to GDR history

\footnotetext{
1 “...in der Deutschen Demokratischen Republik die Gleichberechtigung der Frau wirklich ist” Throughout this thesis all quotations are presented in English. Where possible, the German original is footnoted below.

${ }^{2}$ The terms German Democratic Republic and East Germany are used interchangably throughout this thesis.
} 
through broadly examining how concepts of gender roles moderated women's desires in the GDR. More specifically, it analyses how women's desire gained expression in East Germany, either sexually or materially, and how the regulation of these desires was depicted in East German popular culture, particularly cinema from the 1950s to the early seventies. Its purpose is to determine why the portrayal of certain desires and behaviour were deemed subversive by the SED. In undertaking this study, this thesis not only examines how the authoritarian and regulatory aspects of the SED regime impacted upon women's lives, but also asks how this regulation was internalised and reflected by filmmakers.

\section{Gender Roles, Depictions of Women and Gegenwartsfilme}

In order to understand why certain depictions of women's desires were subversive, the role of women in East Germany under socialism must first be discussed. This is because the way that socialism saw women's place in society changed traditional notions of how women were expected to act and behave. In classical Marxist-Leninist ideology, due to women's financial dependence on men, women, like the proletariat, were fundamentally oppressed as a class under capitalism. Indeed, gender inequality was seen as "the first historical class difference" (Engels qtd in Rinke, 2006: 18). In order to emancipate women from this class oppression, women needed to be freed from their roles as domestic slaves and allowed to enter the workforce in order to gain economic independence and realise their productive potential. As a result, women's involvement in the workforce functioned as an indicator of women's emancipation and also of the success of the socialist project as a whole. This view is reflected in the seminal socialist 
text Die Frau und der Sozialismus (Woman Under Socialism) by August Bebel, where Bebel claims women's emancipation as the "final goal of our social development" (1971: 349). Furthermore, the construction of the GDR as a gender equal society aided in the self-definition of the GDR as a "society of equals" and highlighted East Germany's moral superiority over West Germany. Given that women played such a key role in the socialist project and in the construction of the GDR as a moral state, women were expected to uphold the traits of the socialist personality: to be fully employed, at the same time as being politically active and maintaining the household and maternal duties.

These gender roles imposed on women in the GDR not only moderated how they were expected to behave, but also how women were to be depicted in cinematic portrayals of East Germany. The importance of women's emancipation to the implementation of socialism by the SED meant that women in East Germany occupied a unique role within society, acting as a "seismograph" of social conditions (Rinke, 1998: 209). Because women's emancipation stood for the successes and moral superiority of socialism over capitalism, only the emancipated woman - worker, wife, mother, politically involved - exemplified the feminine traits of the socialist 'new man;' the fully developed sozialistische Persönlichkeit, or socialist personality. The image and personality of such an idealised woman was often adopted by East German artists, writers and filmmakers to highlight and portray the accomplishments of socialism in creating a new societal order. This prompted film critic Hans-Rainer Mihan to remark that in East German films "heroines are representative of the possibilities of human development tout court" (qtd in ibid: 209). 
Importantly, the image of this ideal socialist woman was also used to instruct the viewer on the expected mode of behaviour under socialism. In engaging the viewer in the films didactic mission, filmmakers routinely asked themselves questions like

What kind of behaviour is socially relevant in our times, in the socialist society of today? What kind of behaviour is historically outdated and, as such, to be shown in a critical light? What does the exemplary socialist person look like in reality and how can we focus on him? (Meyer qtd in Rinke, 2006: 6)

This was particularly the case for a genre of films known as Gegenwartsfilme.

Gegenwartsfilme, or contemporary screen dramas, are defined by German film scholar Andrea Rinke as a genre of films that are set

in the present day of the contemporary GDR...The term Gegenwartsfilm usually refers to social dramas, which addressed and problematised controversial issues (rather than comedies, thrillers or other films set in the present) (2006:4)

Between 1950 and 1971, when the SED was led by Walter Ulbricht, Gegenwartsfilme were often heavily didactic, and entrenched in socialist realist aesthetics which called for the portrayal of positive heroes and plots centred on industrial production (Kuhn, 1988:

9). During this period, female characters were often idealised socialist heroines, reflecting the successes and values of East Germany and the socialist personality, thus acting as a role model for female viewers. Often these female characters were professionals, working in traditionally male dominated fields, while at the same time balancing motherhood and family responsibilities (Rinke, 2006: 7).

However, the change in leadership from Ulbricht to Erich Honecker in 1971 brought with it a more critical, and less didactic, use of cinema. As pointed out by film historian Joshua Feinstein, Gegenwartsfilme moved from portraying the present as a "mediating stage between the past and the future" towards a depiction of the present that 
emphasised "ahistorical existence, the diurnal" (2002: 6). ${ }^{3}$ This development was also reflected in Gegenwartsfilme that featured female protagonists and female centred storylines (also known as Frauenfilme, or women's films). In her analysis of Frauenfilme from the seventies, Rinke shows that female characters moved from being instructional figures for female viewers to more realistic, ordinary heroines facing daily struggles (2006: 8). In contrast to the socialist models of the fifties and sixties, these ordinary heroines were "rebels" criticising socialist life from within, which coincided with the turn towards a more critical use of cinema (Rinke, 1999, 2006).

Using the frameworks of Feinstein and Rinke, this thesis looks at the manner in which women's sexual and material desires were portrayed in Gegenwartsfilme from the Ulbricht era to the early years of Honecker's rule, and how the move towards more "ahistorical" depictions of existence and less idealised female protagonists impacted upon the depiction of women's desires. However, this thesis builds from these two studies in that it does not solely focus on trends in the cultural sphere, but argues that the film analyses must be understood in relation to the state's own rhetoric and societal developments that sought new ways to regulate women's desires at this crucial time in East German history. Furthermore, Rinke begins her study in 1972 on the assertion that prior to this date portrayals of women were confined to idealised socialist heroines, citing only a few examples. This study takes the focus back to the immediate post-war era, examining the depiction of such ideal heroines in order to reveal a more nuanced portrayal of women's subjectivity and filmic portrayal. Finally, in tracing the

\footnotetext{
${ }^{3}$ In making this claim, Feinstein distinguishes between Gegenwartsfilme and Alltagsfilme, where Gegenwartsfilme refers to the films produced in the Ulbricht era and Alltagsfilme refers to those made under Honecker (those that focused on a more diurnal depiction of the present) (Feinstein, 2002: 6). For the purpose of this thesis, such a distinction will not be made and the term Gegenwartsfilme will be used to describe both groups of films.
} 
development from the post-war era to the early seventies this thesis analyses four Gegenwartsfilme together with ideas advanced in a signature novel on the subject of women's desire, another departure from the purely cinematic studies of Feinstein and Rinke. In doing so the thesis traces the development from the 1950s when depictions of desire emphasised the importance of socialist values for women to the early seventies, when desire was used by filmmakers as a vehicle to comment on the failure of the GDR to tolerate the protagonist's quest for self-fulfillment and to construct a feminine alternative to SED style socialism.

Importantly, as this thesis shows, any desires that were portrayed as encouraging movement away from the collective were regarded as subversive by the SED. This was particularly the case in the portrayal of sexual desires. In each of the films examined in this thesis, female sexual desire is cast at odds with socialism and in need of regulation, especially when the desires are predicated upon an autonomous need for fulfillment. It is argued that because sexual desires are based within the private sphere, they were beyond the control of the SED. Furthermore, the search for fulfillment through the realisation of sexual desires signified a need for fulfillment outside of participation in the workforce and the collective and as such these desires were viewed by the SED as contrary to socialist values. In the 1950s the subversive potential of women's sexual desires was used to illustrate the danger of the capitalist lifestyle and the importance of socialist values for regulating sexual activity. By contrast, films in the 1970s intentionally portrayed subversive behaviour in order to criticise the SED. In comparison, women's material desires were not depicted as subversive, but rather as being in accordance with true socialism. This is largely due to the control the SED wielded over the production of 
consumer goods, which meant that these desires could be more easily regulated.

Material desires were chiefly portrayed as a female vice in need of regulation by a stern male voice and socialist values. Again, material desires were depicted in

Gegenwartsfilme from the fifties to instruct women on the importance of thriftiness in the post-war East German economy. By the 1970s, however, they were deployed as a device with which to comment on the problems of material production in the GDR.

This thesis also aims at contextualising the portrayal of women's desires in Gegenwartsfilme within the social and political developments of the period. These changes had a significant impact upon the move towards more critical depictions of life under socialism, and more specifically the portrayal of 'ordinary' women. The following sections briefly outline the early developments made in GDR cultural policy and, secondly, women's policies or Frauenpolitik.

\section{Deutsche Film-Aktiengesellschaft}

The move towards more critical depictions of women's desires not only fits within developments in Gegenwartsfilme, but also as the result of social and political changes occurring in the GDR, which impacted upon cultural policy. All East German films were produced by the Deutsche Film-Aktiengesellschaft (German Film Corporation, DEFA), the state-owned film studio and production agency, formed under the authorisation of the Soviet Military Administration on May 13, 1946. As Cold War tensions mounted, the separation between west, and the increasingly Stalinist east was visible in the organisation and directorship of DEFA in the years between its formation 
and the establishment of the Democratic Republic in October 1949. ${ }^{4}$ In 1947, DEFA became jointly owned by the Soviet Union and the SED, and two Soviets, Ilja Trauberg and Alexander Wolkenstein, joined the DEFA board of directors (Allan, 1999: 4). Furthermore, an agreement between the Soviets and the East German communist faction led the SED to form a committee to oversee DEFA and to view rough versions of the company's productions (Ibid). A body known as the DEFA-Kommission was also formed to coordinate between DEFA and the SED Central Committee on personnel matters (Ibid). The consolidation of DEFA as an agent of the SED was finalised in 1948, by which time the three original directors of DEFA had all been replaced by official SED Party members.

Just as the development of DEFA reflected the political changes occurring during this period of consolidation in the newly established GDR, the films produced by DEFA reflected the socialist aesthetic promoted by the state. This was attributable to the control exercised by the SED, in particular the DEFA-Kommission, over the studio's productions. The DEFA-Kommission and the DEFA board had control over both the themes portrayed in DEFA productions, as well as the final versions of film scripts. ${ }^{5}$ In an extract from the journals of Bertolt Brecht in 1949, Brecht stated that the only acceptable themes endorsed by DEFA during the early years of the GDR were the "underground movement, distribution of land, two-year plan, the new man etc., etc" (1993: 421, emphasis added). As a result, DEFA Gegenwartsfilme in the fifties reflected

\footnotetext{
${ }^{4}$ Between the years 1948 and 1949 the SED went through a process of Stalinisation, following the example of the Communist Party of the Soviet Union, in an attempt to become a "Party of a new type." The first conference of the SED in January 1949 is said to have been the "high point of the Stalinisation campaign" (Herf, 1997: 107).

${ }^{5}$ In a communication to DEFA director Sepp Schwab, Stefan Heymann affirmed that "where films touch on certain topics...not only the DEFA-Kommission but also the relevant board members of the executive committee are to be consulted before the script is finalized" (Heymann qtd in Allan, 1999: 7).
} 
socialist values and were used as an instructional medium to encourage adherence to the Party and socialism. They also followed the tenets of socialist realism, the aesthetic promoted by the SED.

In the years that followed the establishment of DEFA, cultural policy swung between periods of repressive censorship and tight government control to periods of greater artistic freedom, and this was certainly the case during the sixties and seventies. After the death of Stalin in 1953 and the construction of the Berlin Wall in 1961, greater artistic freedom was tolerated, leading to a more dynamic use of aesthetics and plotlines critical of socialism. However, the banning of twelve DEFA films at the Eleventh Plenum, also known as the Kahlschlag, held in 1965, meant that the critical depiction of East Germany and socialism, portrayed in many of the banned films were abandoned in future DEFA productions. It was not until Erich Honecker replaced Walter Ulbricht as the First Secretary of the Central Committee of the SED in 1971 that cultural policy in the GDR was again liberalised with Honecker famously calling for "no taboos" in the production of art in the GDR, signalling to many filmmakers a move away from the repression brought about by the Kahlschlag.

\section{Frauenpolitik}

The change in leadership from Ulbricht to Honecker also spelt a change in the direction of women's policy, or Frauenpolitik, which heavily influenced the change in depictions of women. During the 1950s and 1960s the main task of the Ulbricht administration was to consolidate socialism in East Germany, including the implementation of measures to ensure gender equality and the adoption of socialism by women. As previously 
discussed, women's emancipation was equated with the involvement of women in the workforce. As such, many of the early examples of Frauenpolitik aimed at encouraging women to enter the workforce, through equalising pay and harmonising women's roles as mothers and caregivers with their new roles as workers in an attempt to make women's work "less guilt inducing" (Herzog, 2008: 71). ${ }^{6}$ The depiction of model socialist women in Gegenwartsfilme during this period reflects these SED policies, which were intended to show the female viewers what was expected of them under socialism.

In terms of women's sexual behaviour during this period, the goal of the SED was to increase the birthrate devastated by World War II and the 'brain drain' to West Germany, and according to historian Donna Harsch "reproduction ran a close second to production in policy toward women in the 1950s" (2007: 133). While the SED wanted to encourage women to have children they also wanted to confine women's sexual activity to marriage, or at least to committed relationships (Herzog, 2008: 73). Promiscuity and sex outside of a serious relationship were contrary to the concept of the socialist personality and the framework of socialist morality, which called for "cleanliness" in relations between the sexes (Ulbricht, 1958: 19).

Under Erich Honecker not only was there a substantial growth in the area of Frauenpolitik, but there was also a loosening of the conservative attitudes that governed women's sexual desires. Indeed, "Frauenpolitik became one of the top items on the government's agenda" (Rinke, 2006: 20). Two major policies attributed to this period

\footnotetext{
${ }^{6}$ The earliest example of this Frauenpolitik was Order No. 253 made by the Commander-in-Chief of the Soviet Military Administration in 1946, declaring wage equality between men and women. Further, Order No. 234 asked that factories provide laundry, sewing, medical and child care services to enable women to combine their roles as mothers and carers, with their role in the workforce (Harsch, 2007: 45).
} 
include the extension of the Haushaltstag (Household Day; one day off from work per month to attend to household duties) to employed single women over the age of 40 in 1977 and the introduction of a Babyjahr (Baby Year) in 1975, giving women on the birth of their second child one year paid maternity leave and a guaranteed job to return to (Harsch, 2007: 305). ${ }^{7}$ Other policies from this period included giving, in 1972, full-time working mothers with three or more children under 16, a 40 hour work week (without any reduction in wages), together with an increased holiday period (Helwig, 1987: 87); establishing shops on factory premises (Rinke, 2006: 21) and increasing the number of child care facilities (Harsch, 2007: 305).

Furthermore, women's roles were no longer strictly controlled by a prudish sense of socialist morality. Whereas, in the 1950 s and 1960 s premarital sex was viewed as acceptable providing that it took place within a committed relationship leading to marriage, by the early 1970 s the SED was encouraging uncommitted heterosexual relationships (Herzog, 2005: 187). In addition, the Termination of Pregnancy Act, enacted in 1972, gave women the right to obtain first trimester abortions and free access to the oral contraceptive pill (introduced to East Germany in 1968).

In spite of the apparent success of these policies much has been written on the traditional gendered thinking that prevailed throughout East German state and society. Although there were high levels of female employment this was largely in traditionally 'female' sectors, such as the service and textile industries (Shaffer, 1983: 59). In politics, although there was a large female representation in lower levels of governance,

\footnotetext{
${ }^{7}$ The Household Day was a practice adopted from National Socialism, and was legislated for married women in the GDR in 1952 and was extended to unmarried women with children in 1965.
} 
there were only a handful of women in high political positions. ${ }^{8}$ Furthermore, there was a negative attitude towards many of the programs providing women with special training. Given the high cost and time required to implement the programs, several managers were concerned with fulfilling plan requirements (Ibid). Also despite an official call for housework to be divided equally between spouses, women still performed the majority of housework. ${ }^{9}$ It appears, therefore, that despite achieving some success in the pursuit of gender equality, particularly in the area of easing the double burden of working mothers, persisting gender norms existed that prevented women from accessing full equality.

But why was there a persistence of traditional gendered thinking? One problem in implementing change was that many of the policies introduced by the SED, while beneficial to the challenges facing working mothers, only served to reinforce the traditional gendered view that the woman is the primary caregiver and housekeeper (Herminghouse, 1984: 43). This opinion is furthered by Rinke, who argues that despite legislating on the role and duties of women, there was no parallel legislation for men reconciling fatherhood and participation in the workforce, thereby leading to an uneven development of gender roles (2006: 21). Although the new policies reinforced women's co-roles as mother and worker and assisted her in the performance of these roles, there was no impetus to change the attitude of fathers towards child rearing and domestic

\footnotetext{
${ }^{8}$ At the lower levels of power, women represented one fifth of all mayors, and one third of regional deputies, city commissioners and judges. Amongst the political elite Margarete Müller, Ingeburg Lange and Margot Honecker are amongst the most notable female politicians from this period. (Shaffer, 1983: $60)$.

${ }^{9}$ Surveys conducted by the East German Institut für Marktforschung (Institute for Market Research) consistently showed that on average working women worked more hours a day at housework than men (Rubin, 2007: 607 Shaffer, 1983: 65). Between 1965 and 1970, there had been only a 1.4 percent increase in male participation in housework, equating to an increase of slightly more than half an hour per week (Shaffer, 1983: 65).
} 
duties. Furthermore, as pointed out by GDR scholars Irene Dölling and Marlis Allendorf, the process of creating the kind of social changes that the SED was attempting to bring about took time (Equal, 1982: 10-11). According to Dölling, equality between men and women in East Germany was not only a policy direction, but a "private expectation, which people increasingly and inevitably express and realise in their daily lives" (qtd in Equal, 1982: 10, emphasis added). This process of change is also evidenced in a 1970 study of sex roles in East Germany conducted by clinical psychologist Alfred Katzenstein, who acknowledged that while women undertake the majority of housework, the negative attitudes preventing women from pursuing a career and an education are slowly being overcome by "more and more women" who are able to take advantage of the protective measures afforded to them (1970: 253).

\section{Organisation}

It is within this context that this thesis examines the manner in which East German gender roles not only influenced how women were able to desire sexually and materially, but how the regulation of women's desires themselves were depicted in DEFA Gegenwartsfilme. The first chapter will focus on the immediate post-war period, spanning to the Kahlschlag in 1965 . Beginning with the traits and values of the "new man' and socialist morality as regulatory frameworks guiding the roles and behaviours of women, Slatan Dudow's film Frauenschicksale (The Destinies of Women, 1952) is closely analysed. It is argued that this film, through its use of socialist realist aesthetics, portrays women's sexual desires as leading to degeneration and deviance when untempered by socialist values. This message is reinforced by contrasting the moral and 
just socialist lifestyle with the decadent and lascivious lifestyle encouraged by capitalism in West Germany. Dudow's 1959 film Verwirrung der Liebe (Love's Confusions) is also used as an example of how socialist morality controlled what kinds of images the East German citizenry were exposed to.

As a result of the Kahlschlag there was little cinematic innovation between 1965 and 1971 when Honecker took power, making the developments in depictions of women between 1965 and 1971 difficult to trace. Chapter Two addresses this problem by examining Christa Wolf's novel Nachdenken über Christa T. (The Quest for Christa T, 1968) as a bridge in depictions of women between Frauenschicksale and Der Dritte (Her Third, 1972), discussed in the third chapter. This text was very influential in moving aesthetics away from socialist realism and towards more subjective authorship. As such, it also helped establish a role for women's subjective experiences in the GDR. Furthermore, the text deals with questions of ideal and reality, and the need for selffulfillment, all issues that would be taken up in the cinema of the 1970s. The second half of the chapter is dedicated to the societal changes that occurred during Honecker's rule, in particular the move away from socialist morality as a regulatory framework controlling women's desires, the instrumentalisation of female characters and constructions of alternative 'female' socialisms, and the increased cultural freedom granted to artists in the era of "no taboos."

The purpose of tracing these developments in GDR history and depictions of women's desires is to closely analyse two films from the early seventies: Egon Günther's film Der Dritte and Heiner Carow's Die Legende von Paul und Paula (The Legend of Paul and Paula, 1973; 'Die Legende'). These two films are consummate examples of 
Frauenfilme from the early years of Honecker's rule, and are frequently cited as subverting socialist values. It is argued that during the early 1970s in East Germany, as depicted in Der Dritte and Die Legende, in spite of the significant societal changes occurring at the time, women were still constrained by collective ideals based on notions of traditional patriarchal gender roles. Specifically, women's sexual desires were circumscribed within collective and patriarchal norms, imposed by the socialist society. In portraying sexually assertive heroines in search of personal fulfillment the two films not only subvert the traditional gendered expectation of a passive female lover, but in so doing also subvert basic socialist values held by the SED. Der Dritte focuses on the success of the emancipation of women, and asks whether women's public emancipation has been matched by private freedom from gender norms. Die Legende, on the other hand, asks a far more fundamental question; whether the quest for individual private happiness can ever be realised under socialism. As such, the two filmmakers use the heroine's search for self-fulfillment through sexual desire to comment on socialism's failure to accommodate individual happiness. Importantly both films cast love (and sexual desires) and materialism as opposing modes for fulfillment, and in doing so appeal for the adoption of more humanist values by the SED.

Women's desires were subjected to greater scrutiny, and women were expected to conform to the collectivised ideal to a greater extent than men. This was largely due to the roles which women were assigned by the East German state; women, like men, were expected to take part in every level of East German society. However, unlike men, women were under greater scrutiny to conform to the socialist ideal. This was due to the utmost importance of women's emancipation in Marxist-Leninist discourse, which is 
seen as an indicator of the greater proletarian emancipation. Accordingly, women were pushed into the workforce, and into the "triple burden" of domestic duties, employment and political participation (Herzog, 2008: 72). Women were also held to a stricter socialist ideal due to the importance of the mother in the family unit, particularly her role as educator of her young, socialist offspring. These values were imposed upon women in the GDR through policy and in the cinematic portrayals of idealised socialist women. As time passed, and generations were socialised under the SED rule, the need to enforce and consolidate socialist values waned, instead there was a growing need for a 'domestication' of socialism, a turn towards values of the individual and fulfillment. This was aptly portrayed by filmmakers, who in the 1970s increasingly used female protagonists, symbols not only of the domestic sphere, but also of the potential of socialism. The quests for fulfillment by Margit, Paula and Christa $\mathrm{T}$ all signify a call for a more individualised socialism, taking account of desires, emotions and longings. 


\section{Equality - Without Masculinisation}

What's wrong with wanting a pretty dress? Don't I also have the right to a little happiness? (Dudow, 1952) ${ }^{10}$

Following the example of homo sovieticus in the Soviet Union, in the early years of consolidation of socialist rule in East Germany attempts were made to create an antifascist socialist citizenry that no longer identified with fascism or Hitler and adhered to the ideals of socialism. In promoting this anti-fascist identity to both men and women, the SED sought to construct a socialist personality, a 'new man,' whose traits embodied the values and ideals of socialism. Full time employment, adherence to the ideological aims of socialism, thriftiness and clean living were promoted as characteristics of this model socialist citizen. This socialist personality was constructed upon a moral framework, which enabled actions and behaviours that fell outside of the norms and values of socialism and the socialist personality to be defined as immoral and antisocialist. In doing so, adherence to socialism was fundamentally linked to the manner in which a person behaved, indicating that any action or attitude that could be construed as detracting from the people's revolutionary spirit was a deviation from the socialist norm and therefore immoral. Although there was some initial reluctance in actively promoting this new identity to women, by the 1950s the SED was increasingly encouraging women to adopt socialist ideals and become 'new socialist women' (Harsch, 2007: 29). Promoting socialist values to women was important not only because they represented the majority of the population in post-war East Germany and were therefore a possible

\footnotetext{
10 “Aber was soll dann schlecht daran sein das ich ein schönes Kleid haben wollte. Hab' ich nicht auch das Recht ein bisschen Glück?"
} 
support base for the SED, but also because the emancipation of women and gender equality were fundamental values in socialism.

The socialist personality and socialist morality played a key role in the construction of women's roles under socialism, both in the public and private sphere. Indeed, by using a framework of morality to define certain behaviours, the SED was given a new language with which to control women, outside of the 'western' patriarchal discourse of traditional gender roles. Not only were women expected to hold a job and be politically active, but as outlined by SED leader Walter Ulbricht in the 1958 "Ten Principles of Socialist Morality and Ethics," women were also expected to live cleanly in their relations with men and respect family values (Ulbricht, 1958). As such, women's sexual desires were very much at the mercy of this socialist morality. The conservative state attitude towards sexual relationships mandated that sex be confined to committed relationships and should result in reproduction (Herzog, 2008: 73; Poiger, 2000: 180). Any actions originating from a woman's desire for sexual fulfillment or for pleasure were both immoral and anti-socialist. Within this rubric there was certainly no room for promiscuity or for sex as a result of a desire for pleasure. On the other hand, women's material desires were more acceptable to the socialist regime. Although there was an expectation of thriftiness, because the SED could more easily control the material sphere through production, women's material desires were not perceived as threatening as autonomous sexual desires.

The traits of this new woman were aptly portrayed in the East German cinema of the fifties. She is a worker, comrade and mother. Furthermore, her private behaviour reflects the norms of socialist morality, including the portrayal of her private desires and 
longings. One such example is Slatan Dudow's film Frauenschicksale. This film sends a very strong message regarding the manner in which women were expected to behave under socialism. Through images of Western decadence and the degeneration brought about by capitalism, Dudow warns women about the dangers of desire. Un-tempered sexual desires lure women away from the hard-working revolutionary spirit of socialism toward a self-indulgent, "you only live once" existence. Similarly, material desires are portrayed as a female weakness that only socialism can cure. Dudow's depictions of desire coincided with the constructions of socialist morality and the socialist personality that were being promoted and policed by the SED. In using the didactic style of socialist realism, Dudow illustrates how the ideal socialist woman was expected to behave. This chapter examines the manner in which women's desires, both material and sexual, were regulated by the East German state. Just as traditional gender roles moderate women's desires, the gender roles and morality promoted under socialism equally regulated the manner in which women could desire. It explores the ways in which Frauenschicksale functions as a reflection of SED policy on women generally, and analyses how the regulation of women's desires was depicted in the cinema of the fifties and sixties. It will firstly examine the construction of and values associated with the 'new man' and socialist morality, and the way they influenced women's roles and desires, before moving onto a sustained analysis of Frauenschicksale. It argues that the values of socialist morality were essential to the depictions of women in the fifties and sixties, and that films that moved away from the tenets of socialist realism or socialist morality were either censored or banned, culminating in the banning of twelve DEFA films at the 1965 Eleventh Plenum. 


\section{The New Woman and Socialist Morality}

At the Fifth Party Congress of the SED in 1958, the stated goal of the Party's cultural policy was to create a socialist national culture based on the attainment of economic equilibrium and the creation of a "new socialist human being" (Poiger, 2000: 195). This concept, however, was not newly created in 1958, but had been promoted in East Germany since its post-war Soviet occupation, reproducing the Soviet model of homo sovieticus, the 'New Soviet Man,' as a concept and set of values manifested in policy and aesthetically in art and film (Haynes, 2000; Mosse, 1996). As a concept it formed a cornerstone of post-war anti-fascist education. Indeed, the 'new man' can be seen as an important intermediary in the negotiation of a new socialist future, one constructed in direct opposition to western capitalist values. This is affirmed by historian Young SunHong, who argued that the 'new man' and its corresponding values:

must be seen as attempts to forge a positive identity for the new socialist state while avoiding the twin ideological dangers posed by the memory of Nazi racial policies and the implicit connections made between health, consumption, and freedom in the pluralistic consumer society to the west (2002: 327)

It is clear that the concept of the 'new man' was used by the Soviets to redefine German identity over and against both National Socialism and trends in the neighbouring West Germany (Ibid). ${ }^{11}$ In essence, the goal was to establish an East German socialist personality that would serve the dual purposes of creating allegiance to socialist rule and assist in the rebuilding of East Germany.

\footnotetext{
${ }^{11}$ A further rationale for the promotion of a "new man" lies in the need to re-educate the German population, who had been so supportive of National Socialism. Herf argues that the Nazi past was used by the Communists in post-war East Germany as a justification for establishing an "educational dictatorship" (Herf, 1997: 30). The link between the "new man" and antifascist re-education are discussed further below, in the section regarding the promotion of the values of the "new man."
} 
In using the concept of the 'new man' to create a socialist personality the SED was attempting to reframe gender roles to fit within the socialist ideal of gender equality. Although historian Frank Biess links this redefinition of German identity to masculinity and the centrality of returning German POWs to the reconstruction of East Germany and the establishment of socialism, similar remarks can be made regarding the need to reformulate femininity (1999: 144). Biess argues that while the returning POWs posed a threat to the regime, they also offered socialists a great opportunity to craft a new antifascist identity. As soldiers, they were representatives of the ideology of National Socialism, which the Soviets wanted to jettison. Furthermore, as prisoners of the Red Army, these men had faced deprivation and forced labour in Soviet POW camps, possibly turning them against the occupying force in East Germany, and the newly established SED (Ibid). On the other hand, they were mostly men in their prime working years who had experience and were familiar with the Soviets (Ibid: 145). As such, these men presented a large workforce, with the potential to adapt quickly to a "pro-Soviet East German identity" (Ibid). However, the female population of East Germany also offered similar advantages and disadvantages in the dissemination of this new identity, and as such were actively targeted by the SED to become 'new women.' Firstly, just as the POWs were emblematic of National Socialism, it was popularly believed that women were the most ardent supporters of Hitler and were responsible for his rise to power (Harsch, 2007: 33; Harsch, 2000: 161; Heineman, 1999: 177). ${ }^{12}$ Adding to this, the mass rape of East German women at the hands of Red Army officers led to the suspicion and

\footnotetext{
${ }^{12}$ As pointed out by Harsch, this attitude prevailed in spite of consistently lower levels of female votes for the NSDAP (Harsch, 2007: 29).
} 
fear of the Soviets amongst women. ${ }^{13}$ In spite of this, women comprised 57.5 percent of the population in 1946 (Statistical Yearbook, GDR qtd in Shaffer, 1981: 7) thus representing a considerable potential workforce, needed for the rebuilding effort. Additionally, many of these women were in their prime working years, with women between the ages of 20 and 40 representing the greatest numbers of refugees (Harsch 2007: 25). Despite these prospective disadvantages (or perhaps because of them) the SED promoted and encouraged the development of a socialist 'new woman,' and the image of this woman was increasingly promoted in the GDR, both through legislation and aesthetics throughout the 1950s and 1960s.

But what were the expectations of the ideal socialist woman and how did they reframe gender roles? In a speech by then leader of the SED, Otto Grotewohl, to returning POWs in 1945, Grotewohl emphasised that these potential new men or "antifascist-democratic citizens" (Biess, 1999: 146) should not be apolitical and should also work hard for the creation of a "unified and socialist fatherland" (Grotewohl qtd in ibid: 148, emphasis added). These two traits, involvement in politics and employment, represent the primary qualities promoted by the SED, and were fundamental to the creation of a socialist 'new man.' Indeed, the importance of employment to the new socialist identity cannot be overemphasised, as it not only forms the crux of the socialist

\footnotetext{
${ }^{13}$ This point is clearly illustrated in the works of Harsch, Grossmann and Naimark, who each discuss the extent and profound impact of the mass rape of East German women at the hands of the Red Army. It has been estimated that two million German women were raped by Red Army soldiers, with many during the week of mass rapes in Berlin from April 24 to May 5, 1945, when the Soviets were securing the city (Grossman: 1995, 189). The practice of mass rape continued until mid-1946, resurging in 1947. In terms of the impact of these rapes on women's attitudes towards the occupying Soviets, it has been argued that the mass rape of women in the Soviet Zone cost the Soviets and the SED more support than any other policy enacted in the post-war Soviet Zone (Harsch, 2000, 2007; Naimark, 1995). While rapes also occurred in the West, as pointed out by Naimark, the experience of rape "became part of the social history of the Soviet zone in ways unknown to the Western zones" (Naimark qtd in Grossmann, 2007: 49). For further details see: Grossmann, 1995, 2007; Harsch, 2007, 2000 and 1997; Naimark, 1995 and Kuby, 1965.
} 
identity, but the workplace would also come to serve as the main location for social interaction in the GDR. To illustrate this, Article 24 of the 1968 Constitution of the GDR maintains that "socially useful activity is an honourable duty for every able-bodied citizen. The right and the duty to work form an entity" (qtd in Shaffer 1981: 14). ${ }^{14}$ As such, Article 24 implicitly states that by granting all people, including women, the right to work, these people in turn have a duty to work for socialism. It serves to emphasise that working in the GDR was not merely a right, but was also "considered a legal obligation" (Ibid: 14). This statement is further exemplified in Article One of the 1974 Constitution which states that the "German Democratic Republic is a socialist State of the workers and farmers" (Lohmann, 1977: 20), implying that those who chose not to work do not belong to the state. ${ }^{15}$ The 'duty to work,' however, was more onerous than merely being employed; it involved gaining and maintaining skills and being an active employee. The ideal 'new man,' therefore, would not only hold a job, but would actively train to gain new skills and further education. This was of particular importance given the lack of skilled workers in post-war East Germany and the 'brain drain' of East German workers to the West. The ideal worker would work for the greater good to rebuild East Germany under socialism. Similarly, not being apolitical, as referenced by Grotewohl, did not merely mean holding an opinion, but rather meant active involvement in the SED, one of its various satellite organisations, or one of the many work-place groups. Indeed, Article 21 of the 1974 Constitution states that the right to participate and shape East German society is a "high moral duty for every citizen" (Ibid: 29). ${ }^{16}$

\footnotetext{
${ }^{14} \mathrm{NB}$ : this article was not altered during the 1974 revision of the Constitution.

15 "Die Deutsche Demokratische Republik ist ein sozialistischer Staat der Arbeiter und Bauern"

16 "Eine hohe moralische Verpflichtung für jeden Bürger"
} 
The 'duty to work' was of the utmost importance for women, due to the importance of women's economic emancipation to socialism and the dire need for workers in post-war East Germany. While Grotewohl's comments quoted above were directed specifically towards men, women were also encouraged to become involved in politics and the workforce. Similarly to the proletariat under capitalism, women were viewed as a class oppressed through the institution of marriage, where women were treated as goods to be traded between a father and potential spouse. In this situation women's means of production were confined to reproduction, and she was without a class consciousness. By enabling women to enter the workforce, the SED sought to free women from the last vestiges of capitalism by giving them economic independence from men. According to the SED this not only created gender equality, but also awoke women's revolutionary spirit. This attitude towards women's emancipation is affirmed by the $19^{\text {th }}$ Century German socialist thinker August Bebel, who concluded his text Die

Frau und der Sozialismus with:

The complete emancipation of woman, and her equality with man is the final goal of our social development... and this realization is possible only by a social change that shall abolish the rule of man over man-hence also of capitalists over workingman. (1971: 349).

Bebel's statement reflects the notion that women's emancipation was an indicator of the success of socialism: the more women entered the workforce and gained economic independence, the more successful the socialist project.

The task to involve women in the workforce and create new socialist women marked a significant departure from the traditional gender roles women were previously expected to uphold, and as such the two visions of women's roles often came into conflict. Socialism viewed women's oppression as an economic issue, tied to class, 
rather than as a result of institutionalised gender oppression or patriarchy. Although equality between men and women was pronounced in the 1949 Constitution and officially household chores were to be divided equally between spouses, in reality, women still performed the majority of housework: a 1964 study, conducted by the East German Institut für Marktforschung (Institute for Market Research) calculated that on average working women worked six more hours a day at housework than men (qtd in Rubin, 2007: 607). ${ }^{17}$ Women were expected to shoulder this double burden, or, as it has been labelled by historian Dagmar Herzog, the "triple burden" of employment, housework and political participation (2008: 72), as, although there was no official ban upon women being housewives, or working part-time, there was certainly stigma attached to those women who chose to be housewives or only work part-time, with the 1967 commentary on the Family Law Code stating that housewifery was a sign of a "backward consciousness" (Heineman, 1999: 228).

At the same time as they were encouraged to enter the workforce, women were also encouraged to bear children, indeed, according to Harsch "reproduction ran a close second to production in policy toward women in the 1950s" (2007: 133). The decline in birthrate caused by the war left fertility at 55.7 births per 1000 women in 1947 and if the SED wanted to establish a sustainable workforce for the future this rate needed to increase (Ibid: 135). The desire to increase the birthrate led the SED to afford rights to single mothers, equal to those of married couples. It was a "genuine government objective" to end the shaming of illegitimate children and unwed mothers (Herzog, 2008:

\footnotetext{
${ }^{17}$ See Section 10(1) of the East German Family Code: "Both marital partners shall share in the education and care of their children and in running the household. Relations between the spouses shall be arranged in a manner allowing the wife to reconcile her vocational and social activities with motherhood" (qtd in Equal, 1982: 75).
} 
72). This objective was realised in the provisions of the Law for the Protection of Motherhood that gave single mothers equal rights. Of course, increasing the birthrate was the primary objective of such proclamations. The realisation of this goal was also assisted by the tightening of abortion legislation in the 1950s.

The importance of motherhood to the project of re-educating East Germany under the norms and values of socialism cannot be underestimated. Education, much like involvement in the workforce, was central to life in the GDR and became a leitmotif throughout the course of East German history, which led one noted GDR historian to suggest that its entire history could be conceptualised as "the story of a failed education project" (Wierling, 1999: 315). This was especially true during the immediate post-war years, when the task of re-educating the East German population was central to the promotion and creation of the socialist identity. As such, motherhood and the task of raising children gained new found importance. Women were, quite literally, the vanguard of the next generation. Perhaps because of this, and to gain further control over these future generations, the 1965 Family Law Code stated that the task of bringing up children fell to the community at large (Family Law Code qtd in Shaffer, 1981: 33). Similarly, the "Ten Principles of Socialist Morality and Ethics," a document presented at the Fifth Party Congress in 1958, stated that families needed to ensure that their children were brought up "in the spirit of peace and socialism into educated humans with a strong character and a steeled body" (Ulbricht, 1958: 16). ${ }^{18}$ To assist in this task, children were expected to be involved in the major youth organisations, the Ernst Thälmann Pioniere and the Freie Deutsche Jugend (Free German Youth, FDJ).

\footnotetext{
18 "Du sollst Deine Kinder im Geiste des Friedens und des Sozialismus zu allseitig gebildeten, charakterfesten und körperlich gestählten Menschen erziehen."
} 
In order to ensure adherence to socialism and the traits associated with the ideal socialist woman the SED constructed a moral framework. By using a framework of morality the SED hoped to effectively gain access to, and control of, the private sphere. At the same time, concepts of morality were interwoven within notions of the ideal socialist citizen, so that the SED removed morality from the private sphere and into the public realm where it could be regulated more openly. Indeed this occurred in 1958 when statements of socialist morality were made clear in the "Ten Principles of Socialist Morality and Ethics" which mandated the ten rules that the new socialist person should live by. This list connected "healthy, clean and proper living" and sexual relationships with adherence to socialism, thus conflating private morality with political commitment (Evans: 2005; Feinstein, 2002: 94; Ulbricht, 1958 15-16). In terms of women, as a secularised and gender equal society, the SED could not use religious concepts or patriarchal discourses to regulate women's behaviour. However, using a language of morality enabled the SED to promote socialist ideals at the same time as censuring private behaviour that did not reflect these ideals. Linking adherence to socialism to moral behaviour indicates that any action or attitude that could be construed as detracting from the people's revolutionary spirit was not only a deviation from the socialist norm, but also immoral. Reiterating this, Herzog has argued that socialist morality along with the socialist personality were "highly authoritarian concepts - mandating as they did certain character traits such as nonegoism and solidarity with others, personal responsibility and decency, nonmaterialism and commitment to progress" (2005: 186). Herzog continues on to argue that daily life in East Germany was highly monitored by the state security service (Staatssicherheitsdienst or Stasi), which was tasked with 
ensuring adherence to the norms of socialist morality (Ibid). Socialist morality, in other words, not only had a large impact upon what kinds of behaviour were acceptable, but also determined the extent to which citizen behaviour was policed. As such, the only acceptable behaviour under socialism was to follow the norms of socialism: for women this meant being employed, politically involved, gaining further skills, and reproducing, reflected in the image of feminine socialist ideal - worker, comrade and mother - used by filmmakers to instruct women on the expected mode of behaviour. This point is reiterated by historian Elizabeth Heineman, who argued that "ideally, women would marry, have children, work for pay and be politically active - all at the same time" (1999: 177).

But, what implications does this socialist morality have for women's ability to desire? Although socialist morality was "more than sexual mores" (Herzog, 2005: 186), and included traits like non-materialism, at least in theory women's sexual desires were very much regulated by the socialist sense of morality, particularly given the emphasis on "clean and proper" (Ulbricht, 1958: 16). Although these two concepts were not qualified in the "Ten Principles of Socialist Morality and Ethics," Ulbricht also outlined the need for "cleanliness" in relationships between the sexes and stressed the importance of respecting the family at the Party Congress (Ibid: 19). Such a statement implies a socially conservative attitude towards sexual relationships, one that mandates that sex be confined to committed relationships and should result in reproduction, reflecting the importance of reproduction to the rebuilding project. Within this rubric there is no room for sex for pleasure, reflected in the cinema of the period where any hints of female sexual assertiveness or sensuality were censored. This point is also reaffirmed by 
Poiger, who argued that the rock ' $n$ ' roll culture of the late fifties challenged the "ideologies that, in both Germanies, had sought to confine women's sexuality to the sphere of marriage and motherhood" (2000: 180$){ }^{19}$

Material desires were also regulated by socialist morality and were seen as a mechanism through which to create the socialist personality. As suggested in the "Ten Principles of Socialist Morality" thriftiness was a fundamental trait of the socialist personality. This was the result of dire material conditions in East Germany. Due to the scarcity of goods and food in the post-war period, thriftiness and frugality were essential to survival. Given that rationing did not fully end until 1958 , non-materialism played a key role in the rebuilding of East Germany. ${ }^{20}$ Frugality was particularly important for women, as women were the primary household shoppers (Pence, 2008: 288). This led to a gendering of the consumer sphere, as evidenced by the selection of Elli Schmidt to head the State Commission for Trade and Supply. As argued by Katherine Pence, "gender roles were central to the construction of Schmidt's position"; as a woman, Schmidt was seen as an expert in shopping and consumerism, her experience providing for her family qualifying her for the position (Ibid: 295).

The control over consumer goods exercised by the SED was also viewed by some as a mechanism through which the SED could shape the socialist personality. Martin Kelm, an East German industrial designer and founder of the Central Institute for Design, an advisory body in the Ministry of Culture, wrote in his dissertation

\footnotetext{
${ }^{19}$ It is important to note, however, that there was no prima facie rejection of sex in itself. Indeed, sex (including premarital sex, and sex outside of wedlock) was encouraged as a means of "orienting people toward the future": the goal of building a Utopian Communist society (Herzog, 2008: 73). The concern was that certain sexual desires and behaviours, such as sex outside of a serious relationship or promiscuity, had the potential to distract from the socialist cause and were unacceptable within socialist morality.

${ }^{20}$ Although rationing of vegetables, tobacco, ersatz coffee, soap, shoes and textiles ended in 1952, it was not fully abolished until 1958 (Pence, 2008: 291).
} 
"Consumption in socialism is not simply a matter of needing something and getting it, but rather a process by which the socialist personality is created" (qtd in Rubin, 2006: 161). While there was an expectation that women be frugal, because the flow of consumer goods was controlled by the state, consumers were unknowingly shaped into the socialist personality and the regulation of women's material desires was not as stringently policed as their sexual desires.

One of the mechanisms used to promote socialist morality and socialist values to women was the portrayal of ideal socialist citizens in films using the aesthetics of socialist realism, reaffirmed by Mihan who pointed out that in East German films "The question is how concepts of personality on screen can offer the spectators help with their daily lives" (qtd in Rinke, 2006; 6). By controlling how life under socialism was portrayed through bodies like the DEFA-Kommission, the SED sought to impose a sense of socialist morality on to women. In order to promote ideal socialist values filmmakers (along with artists and writers) were expected to use socialist realist aesthetics. The tenets of socialist realism, established at the 1934 Congress of the Soviet Writers' Union, called for a focus on industrial production, at the expense of portrayals of the private sphere; the portrayal of positive, working class heroes, engaged in the socialist struggle; and an emphasis on the didactic function of art (Kuhn, 1988: 9). This style was filled with the depiction of character types, such as the grieving war widow or the ordinary worker hero and was steeped in socialist morality. Aesthetically, the style stood apart from the innovations of Weimar expressionist cinema and contemporary neorealism. In the post-war period, socialist realism was the only acceptable style for the SED; affirmed in 1952 (the year Frauenschicksale was released) in an SED resolution which stated that 
"only the art of socialist realism, based upon Marxist-Leninism, is capable of reflecting the true objectives [of socialism]" (qtd in Schenk, 2006: 69). ${ }^{21}$ Slatan Dudow's film Frauenschicksale exemplifies socialist realist depictions of life in the GDR, didactically instructing women on the dangers of sexual desire away from socialist norms.

Although DEFA productions were used as propaganda to promote socialist values and morality, many films critiqued the socialist regime as well as upholding its values. These highly fraught productions provide many opportunities for analysis on how the SED envisioned socialist society from its reactions to its depiction. One such example is Slatan Dudow's film Verwirrung der Liebe (Love's Confusion, 1959). On the surface, Dudow tells the story of the romance of four young people, two welleducated students, Dieter and Sonja, and two factory workers, Edy and Siegi. At the time of its release, the film was surrounded by controversy, largely because of a nude bathing scene. Indeed, before it was to be released Walter Ulbricht and his wife, Lotte, had a private screening of the film, in order to determine whether the film was acceptable for release (Feinstein, 2002: 79).

The controversy surrounding this nude scene is as much a comment on socialist morality, as it is an attempt to distance the SED from the sexual freedoms and counterculture of the Weimar era (Ibid: 94). The need to distance SED style socialism from the sexually liberal communist attitudes of the Weimar era comes as the result of the connection between the SED and Stalin (Herzog, 2005: 190). Socialist morality, as promoted by the SED, was a reflection of the conservative Stalinist values inherited by the SED during the Soviet Occupation, when the Party was consolidating its power and

\footnotetext{
21 "Nur die Kunst des sozialistischen Realismus, die auf dem Marxismus-Leninismus basiert, vermag die Wirkllichkeit objektiv widerzuspiegeln"
} 
purging more liberal elements. The sensuality and nudity depicted in Dudow's film, which references the liberal past of Weimar and socialism in Germany are clearly an affront to the more conservative attitudes of 1950s East German socialism.

The nude sequence is also a comment on socialist morality. Any behaviour that stood outside of the prudish values promoted by the SED, such as nude bathing, was to be taken as a sign of disloyalty or even political subversion, particularly since the portrayal of nudity was linked to the exploitative gender relations of capitalism. Given this value system, a scene featuring nudity is as much about casting off the restrictions of socialist society as it is about taking off clothes and as much about freedom of individual expression as it is a critique of a strict moral code. Furthermore, the portrayal of nudity was seen by the SED as a form of sexual commodification, like prostitution and pornography, and as such fundamentally connected with capitalism. As argued by historian Josie McLellan "nudity was most commonly seen as part of a West German and American sexual culture which was both decadent and exploitative" (2009: 146). These attitudes not only extended to visual depictions of nudity, but also public displays of nudity and during the 1950s the SED attempted to ban nude bathing (Ibid).

Such conservative attitudes towards sensuality and expressions of individuality arising from this moral code have direct repercussions for women's ability to desire. They left an indelible mark on how they might express their sexuality since they created clear delineations between acceptable and transgressive desires. Indulging in one's own feelings was deemed 'individual' and subversive. This argument is especially evident in Dudow's other film analysed below, Frauenschicksale. 
The controversy surrounding Verwirrung der Liebe clearly demonstrates that any free sexual expression was construed as a deviation from the socialist norm, with the potential to detract from the people's revolutionary spirit. As demonstrated in the call for cleanliness between the sexes made at the 1958 Party Congress, there was no room for individual sexual desires in the rebuilding of socialism, except when these desires were connected to reproduction. It is important to note, however, that there was no prima facie rejection of sex in itself. Indeed, sex (including premarital sex, and sex outside of wedlock) was encouraged as a means of "orienting people toward the future": the goal of building a Utopian Communist society (Herzog, 2008: 73). Rather, the concern was that certain sexual desires and behaviours, such as sex outside of a serious relationship or promiscuity, had the potential to distract from the socialist cause. This is also reflected in the traditional Marxist discourse on women's sexual appetites. Although Marx and Engels both saw marriage as primarily an economic institution where women were treated as instruments of production and objects of desire, and believed that this gender relationship would change under socialism, neither meant socialism to lead to women's free sexual expression, or irregular sexual relationships (Merfeld, 1972: 49-50).

Women's material desires, on the other hand, were more acceptable within the socialist state. Not only was consumerism thought of as a female domain, but material incentives were used by the SED to encourage participation amongst women, with attendance at the first conference of the Demokratischer Frauenbund Deutschlands (Democratic Women's League of Germany, DFD) being rewarded with extra rations of food, money and cigarettes (Harsch, 2007: 43). This dichotomy between sexual and 
material desires existed because, whereas the SED could control (and thus manipulate) the production and distribution of material good, sexual desires, based on the need for individual fulfillment, were beyond their reach. Although they could create policy to encourage reproduction, free sexual expression, with the potential to transform and distract from the socialist revolution, was a threat to the newly formed regime. This dichotomy between sexual and material desires, and the SED's attitude towards both was made clear in the two films Der Dritte and Die Legende.

There is, therefore, an apparent tension in the manner in which women were able to desire under socialism in the GDR. While desires, be they material or sexual, were not inherently immoral, any desire that was seen as having the potential to distract from the socialist project was deemed contrary to socialist morality. This was particularly the case for sexual desires, which were not as easily controlled by the SED. However, because materialism was seen as a feminine domain, it was often portrayed as a specifically female vice that could be cured by adherence to socialism. The tense relationship between women's desires and socialist morality and gender roles was made clear in the 1952 film, Frauenschicksale.

\section{Frauenschicksale (The Destinies of Women)}

Born in 1903 in Bulgaria, Slatan Dudow was the director of post-war East Germany, having both cinematic and bona fide anti-fascist credentials. His involvement in cinema began during the Weimar era when he assisted Fritz Lang in the direction of Metropolis (1927), and his first feature film Kuhle Wampe, oder: Wem gehört die Welt (Kuhle Wampe, or Who Owns the World?, 1932) was based on a script by Bertolt Brecht. As a 
member of the Communist Party of Germany (Kommunistische Partei Deutschlands, KPD), he was initially arrested by the Nazis in 1933 and spent the duration of the war in hiding. Upon returning to Berlin in 1946, Dudow became involved in the founding of DEFA. Frauenschicksale was his third film made with DEFA and his first in colour. At the time of its release, Frauenschicksale was met with mixed reviews. Despite winning the best director award at the 1952 film festival in Karlovy Vary in the Czech Republic, Dudow's film was criticised at the SED Film Conference in September of that year for presenting a negative (and Western) protagonist, thus going against the tenets of socialist realism by not exclusively portraying positive role models (Stegmann, 2005: 481). Despite receiving support from Gerhard Eisler, a member of the DEFAKommission, for having produced one of only two German films that did not "bore the masses," the closing words of the conference were:

We will not have further Frauenschicksale's filmed in this manner. We will depict more positive heroines. We will prepare ourselves to create a worthy memorial to such a heroine, like Clara Zetkin (qtd in Schenk, 2007: 71) ${ }^{22}$

Frauenschicksale even remains a subject of disagreement today with some academics claiming it as one of the "great" DEFA films of the early 1950s, while others have labelled it pure propaganda with no artistic merit (Stegmann, 2005: 481). In spite of these criticisms, the film sends a very strong message regarding the manner in which women were expected to behave under socialism: through the use of imagery of Western decadence and the degeneration brought about by capitalism Dudow warns women about the dangers of desire. Furthermore, it reflects the manner in which socialist morality

\footnotetext{
22 "Wir warden wohl keine Frauenschicksale in dieser Form wieder drehen. Wir werden viele andere positiva Heldinnen darstellen. Wir werden uns vorbereiten, einer solchen Heldin wie Clara Zetkin ein würdiges Denkmal zu setzen"
} 
controlled the construction of gender roles and regulated women's sexual and material desires.

Frauenschicksale follows the exploits of Conny, a shameless womanizer from West Berlin. The plot weaves the stories of three of Conny's love interests together, depicting the often devastating impact he has on the lives of these young women. His first love interest, Barbara, is a promising young law student who ends her relationship with Conny early on and goes on to become one of only a few female judges in East Germany. Next, the factory worker Anni is seduced by Conny. She falls pregnant to him, for which she loses her job in the West. When Conny refuses to support her, Anni moves to the East. The most tragic story is Renate's, also a young factory worker. In an attempt to win Conny back (after he broke off the relationship), she goes as far as stealing her mother's money to buy an expensive dress and accidentally kills her young brother while trying to silence him. She is subsequently caught and, in an odd turn of events, her criminal case is heard by Barbara. The film ends positively with Barbara aiding Renate in entering a work-release program. Through this program Renate finds employment at a steelworks, and finally finds love with a fellow worker. Barbara also finds love with a fellow judge, and Anni works for the benefit of the people, making a mass produced version of the dress stolen by Renate. Conny, meanwhile, is finally rejected outright by a young girl working for the FDJ.

Importantly the film reflects the manner in which socialist morality worked to shape women's sexual and material desires. By contrasting the capitalist attitude towards sex and consumerism, which is portrayed throughout the film as inspiring a lifestyle of degeneration, to the decency and modesty of socialist society, the film 
promotes socialist morality and warns women of the danger that the unbridled desires inspired by capitalism can lead to. Furthermore, socialism (and East Germany) is presented as the saviour of the working woman, victimised by capitalism and desire: it is only when the notion of the individual and the lasciviousness and decadence of the capitalist lifestyle are replaced by the upright, moral and selfless nature of socialism that a woman (and man) can flourish.

One of the main mechanisms promoting socialist morality is through emphasising Conny's degeneracy. Conny epitomises the capitalist attitude towards women, sex and consumerism. He leads a lascivious and pleasure seeking life, highlighted in his personal motto "You only live once" (Dudow, 1952). ${ }^{23}$ Throughout the film he is seen prowling the streets, preying on women, who he then treats like objects to be disposed of once he is through. This degenerate attitude towards women is portrayed in his refusal to help Anni, when she is pregnant with his child. Further, he is obsessed with materialism and fashion, always immaculately dressed with silk ties. The degeneration brought about by Conny's lifestyle is clearly depicted in a sequence of Conny and his newest mistress, the Baroness Isa von Trautwald, at a West Berlin jazz club that is subsequently juxtaposed with a montage of an East German steelworks. The lighting, soundtrack and editing used in the portrayal of the two Germanys serves to emphasise the degenerate nature of West Germany and the values it inspires, in comparison to the hard working East. In the West Berlin club, Conny and the Baroness dance wildly along with many other obviously bourgeois couples to a piercing jazz soundtrack. The degenerate nature of these West Berliners is portrayed not only through their convulsive dancing, but dark green and purple lighting serves to accentuate the shadowing, making the dancing bodies

23 "Man lebt ja nur einmal" 
appear even more grotesque. Indeed, when shooting this scene Dudow commented that he wanted "corpse coloured lighting" (1952b: 4). ${ }^{24}$ Adding to this sense of degeneration are shots of monkeys dressed as humans interspersed between the shots of the dancing. The juxtaposition of the monkeys and the dancers emphasises the sub-human, or primal, nature of the dancers. The whole scene serves to portray capitalist life as one of degeneration and deterioration. Although this western lifestyle may lead to greater individual wealth (both Conny and his Baroness are very well dressed), the decadent and lascivious attitude of "you only live once," engendered through capitalism, leads only to decline (Dudow, 1952). Further, the scene reflects the East German state's attitude towards jazz music in the early 1950s, in which jazz was seen as degenerate and an example of the American and West German imperialism that was destroying East German national culture (Poiger, 2000: 59).

These images of Conny's degeneration are contrasted with the glorious East German steelworkers. The montage of the steelworks portrays East Germans working together to rebuild society and sacrificing physical enjoyment, for the greater good. In comparison to the fast editing of the jazz club sequence, the shots of the steelworks are longer, the slower pace emphasising the steelworkers' graceful movements, contrasting with the erratic dancing shown earlier. Also, the brassy jazz music is replaced by a female choir singing Brecht's Das Lied vom Glück (The Song of Happiness), described by film historian Daniela Berghahn as "essentially a eulogy of the socialist work ethos and collectivism" (2005: 187). Unlike the green and purple of the club, the workers are bathed in the red and golden glow of the furnaces, their work seeming majestic in comparison to the seedy West Berlin club. Overall, the stark contrast between the two

24 "Fast leichenhaftes Farblicht" 
scenes demonstrates the purity and hard-working nature of the East German workers, in comparison to the decadent bourgeoisie and Conny's degeneracy. This is reaffirmed by Dudow who stated that the jazz club stood for "the atmosphere of decline of the capitalist world," in comparison to the "healthy optimism of a new world, where work will result in the happiness of all working people" under socialism (1952b: 4). ${ }^{25}$

To a certain extent, this portrayal of the degeneracy brought about by capitalism in Frauenschicksale coincides with the imagery used by the Nazis to demonise what it considered to be 'degenerate' populations. Although Conny is a womaniser, his manner of dress and behaviour plays upon homosexual stereotypes of soft effeminacy and uncontrollable sexual urges from the Nazi era (Micheler, 2002: 96). When not with a woman, Conny is seen prowling the streets in search of a sexual conquest, as if unable to control his sexual desires. He is dressed decadently in suits with silk neck ties, the attention to style giving him an effeminate air. Added to this he is never seen working, but is also never without money, suggesting a questionable and lascivious lifestyle. In using this Nazi imagery to hint at Conny's sexuality, Dudow is not only highlighting his degeneracy, but also underscoring his treasonous behaviour, as hints of same-sex desire were seen as having the potential of luring healthy energy away from the state, an obvious parallel to the way he tempts young women away from the collective (Evans, 2010). In comparison, the burly steelworkers, clad in grey overalls, engaged in hard labour, epitomise Nazi masculinity (Mosse, 1997). Not only do these men display their supreme physical strength, stoking the steel furnaces and carry heavy loads, but when compared with Conny's constant pleasure-seeking, the East German steelworkers'

\footnotetext{
25 "Das eine spiegelt die Untergangsstimmung der kapitalistischen Welt wider, das andere besingt den gesunden Optimismus einer neuen Welt, wo für das Glück aller schaffenden Menschen gearbeitet wird"
} 
muscular masculinity exemplifies self-sacrifice, denying their own temporary pleasure for the greater good. Furthermore, Conny is a loner and rarely seen in the company of other men, making a stark contrast with the steelworkers' camaraderie. A final example linking Conny to the concepts of degeneration prevalent in the Nazi era is his enjoyment of jazz music. Not only were jazz musicians and fans persecuted under the Third Reich, but jazz was seen the ultimate form of 'degenerate music' and linked to sexual excess and "racially inferior" groups, in particular blacks and Jews (Poiger, 2000: 24; Kater, 1992). This attitude towards jazz continued into the 1950 s in both Germanys, where jazz was linked to "sexual transgression and racial decay" (Poiger, 2000: 137). The jazz club scene, therefore, not only emphasises Conny's animalistic, sub-human degeneracy, but hints ever so gently that his behaviour is an extension of the racial discourses disseminated under Hitler, a link deepened in the physical contrast of Conny to the manly steelworkers. By connecting Conny's demeanour to previous discourses of degeneracy, Dudow uses gender and desire to portray West Germany as a site of decline and treason against the GDR.

If Conny's ambiguous masculinity serves to highlight the degeneration of the capitalist world, then the film's depiction of the characters' various femininities serve as a warning against this degeneration and immorality for young women seduced by the decadence of the capitalism. It also demonstrates the importance of socialism, and socialist morality, for women. When Renate first enters the film, she is uninterested in politics, not attending a work meeting on gender equality, telling her friend "what do I care about other women?” (Dudow, 1952). ${ }^{26}$ Instead, Renate steals away to meet Conny: his western individualist values not only enticing her away from the collective, but also

\footnotetext{
26 "Was geht mich die andere Frauen an?"
} 
encouraging her selfish attitude. Once Conny is done with Renate, he begins a flirtation with a more lucrative target, the widowed Baroness. Seeing this, Renate becomes jealous and desires Conny's attention once more, hoping that an expensive dress will impress him. These unrestrained desires lead her to steal her mother's money to buy the dress. When her little brother discovers her theft, he threatens to tell, leading Renate to silence him with a pillow, killing him in the process, the ultimate act of degeneration and deviance. The trial scene, where Renate is being prosecuted for killing her brother, illustrates the fundamental problem with un-tempered desire:

Renate: What's wrong with wanting a pretty dress? Don't I also have the right to a little happiness?

Female Judge: No one begrudges you a pretty dress. And even less the right to be happy

Male Judge: Don't millions of other women also have the right to a pretty dress and a little happiness?

Renate: But I have nothing against other women's happiness!

Male Judge: Not minding isn't enough, we must work for it. There are millions like you (Ibid) ${ }^{27}$

As the male judge makes his final statement, the camera pans across the assembled audience, symbolising the collective. Dudow is suggesting that it is not the desire for happiness or a pretty dress that is at fault, but rather assuming that individual desires are more important than those of the millions of other women who also want a pretty dress. Renate's individualistic attitude, inspired by her desire for Conny, led her to betray the

\footnotetext{
27 “'Renate:Aber was soll dann schlecht daran sein das ich ein schönes Kleid haben wollte. Hab' ich nicht auch das Recht ein bisschen Glück?

Female Judge: Niemand beschreitet Ihnen das Recht auf einen schönes Kleid. Und noch viel weniger das Recht glücklich zusein Male Judge: Haben den millionen anderen Frauen nicht auch das Recht auf ein schönes Kleid und 'ne bisschen Glück?

Renate: Aber ich hab' gar nichts dagegen das andere Frauen auch glücklich werden. Male Judge: Das genügt nicht das mann nichts dagegen hat. Muss doch etwas dafür tun. Diese million sind alle gleiche."
} 
collective, portrayed visually in the audience. The need for women to shed their individual desires, in favour of the collective, is affirmed by Dudow, stating that:

...The destiny of the individual cannot be seen as independent from societal relations. Millions of women, trapped in bourgeois ideology, do not grasp the true meaning of the social questions before which they stand. They fight the battle for a little happiness on their own initiative, each for themselves, and they believe that they can thus master all of life's difficulties. And it is exactly this group of women whom I want this film to speak to and to help free them from their dangerous mistake (1952b: 4$)^{28}$

Importantly, the trial scene comes before the jazz club/steelworks montage, visually suggesting the fate of total degeneracy that Renate has avoided through socialism.

The contrast between Renate and Barbara serves to emphasise the importance of adherence to socialism and socialist morality for young East German women tempted by their desires. Both Renate and Barbara are presented as having suffered as a result of the war: Barbara was in a concentration camp, and Renate's parents were both absent during the war, her father a soldier and her mother working in a munitions factory. Despite having similar histories, it is Barbara's adherence to socialism that saves her from Conny's degeneracy and Renate's fate. Indeed, Barbara typifies the ideal socialist woman - well educated, politically aware and committed to the goals of socialism: throughout the film she is heard speaking out against gender discrimination and inequality and can be interpreted as a reference to Hilde Benjamin, one of the earliest female judges in the GDR and the vice-president of the Supreme Court of the GDR between 1949 and 1953.

\footnotetext{
28 "Das Schicksal des einzelnen nicht unabhängig von den gesellschaftlichen Verhältnissen gesehen werden kann. Millionen von Frauen, befangen in der bürgerlichen Ideologie, begreifen nicht die wahre Bedeutung der sozialen Fragen, vor denen sie stehen. Sie führen den Kampf um ein bißchen Glück auf eigene Faust, jede für sich, und glauben so, alle Schwierigkeiten allein meistern zu können. Und gerade diesen Teil der Frauen will der Film in erster Linie ansprechen und ihnen helfen, sich von ihrem gefährlichen Irrtum zu befreien."
} 
Further emphasising Barbara's ideal socialist credentials is her friendship with fellow concentration camp survivor, Hertha. Hertha, whose name comes from the Germanic Goddess Nerthus, or Mother Earth, stands for the older pre-war KPD generation, sent to concentration camps for their political stance (Grimm, 1888: 1364). In using this name, Dudow symbolically connects the KPD and Hertha's generation to the 'birth' of the GDR, like Mother Earth she nurtures the new generation of socialists. In many respects this narrative reflects one of the founding myths of the GDR, namely that the GDR was founded on the work and lives of Weimar era socialists, who having survived the war passed the torch to the next generation of socialists. As such, Hertha is the "mouthpiece of the film's educative mission" and is often heard reciting socialist texts, such as August Bebel's Die Frau und der Sozialismus (Berghahn, 2005: 184). Working as a trade unionist, volunteering at a factory crèche, firmly committed to gender equality under socialism and teaching this to others, Hertha is the ideal socialist woman and an excellent counter-point to her protégé Barbara.

Renate, meanwhile, has no such role model. She is apolitical and, thanks to Conny's subversive western influence, she is self-absorbed. The contrast between Renate and Barbara emphasises the importance of political education: had Renate been more politically aware and adhered to the norms of socialist morality she would have avoided this fate as Barbara did. This message is further emphasised in the final rejection of Conny by the young FDJ girl. In a discussion of Frauenschicksale, Dudow stated that while Hertha stood for the pre-war generation of socialists, the FDJ girl symbolised the future of socialist women (1952b: 4). Importantly, this girl rejects Conny's advances, her political awareness preventing her from seduction away from the 
collective. In spite of Renate's misgivings, she is offered a chance to change her destiny. While in jail, Barbara offers Renate the chance to join a work-release program, offering Renate salvation in the collective arms of socialism. Through this program, Renate learns the value of work, and finds a husband, suggesting that true love (as opposed to the brief physical affairs offered by Conny) only comes under socialism. ${ }^{29}$

The role of socialism as women's saviour is also emphasised in the story of Anni. Anni's story is similar to Renate, in that her interaction with Conny's degeneration leads her to the righteous path of socialism. When Anni falls pregnant to Conny she is fired from her job. Upon questioning her boss, he responds that he can do what he wants, even invoking the contrast with the east, saying "Thank god we're not in the East, where the workers are the boss" (Dudow, 1952). ${ }^{30}$ Anni eventually moves to East Berlin for the benefits that are offered to working mothers. This story indicates that despite being sexually conservative, socialist morality was not anti-sex; rather the concern was that certain sexual desires and behaviours, such as those practiced by Renate, like sex outside of a serious relationship or promiscuity, had the potential to distract from the socialist cause and were unacceptable within socialist morality. The story also serves to promote the social policies offered to women in East Germany, such as day care facilities for factory workers, and the tolerance that was officially afforded to unmarried mothers. ${ }^{31}$ In doing so, East Germany appears the more moral and righteous state, whereas Anni

\footnotetext{
${ }^{29}$ The notion that socialism provided the ideal location for true love was a longstanding belief in East Germany and is detailed in August Bebel's seminal text Die Frau und der Sozialismus. By enabling women to work, socialism provides women with economic independence from men and ends women's subjugation to the "money transaction" of marriage (Bebel, 1971: 91). This independence allows women (and men) to marry for love, rather than economic needs.

30 "Gott sei dank wir sind nicht im Osten. Wo die Arbeiter zustimmen was der Chef machen soll oder nicht"

${ }^{31}$ In order to improve the declining birthrate, the abortion laws were tightened in the late forties and fifties in the GDR, and unmarried mothers were afforded greater benefits. For more information see: Harsch, 1997.
} 
was cast out of West German society, she is welcomed with open arms in East Germany. Significantly, Anni, upon moving to East Berlin, begins work at a textile factory making a mass produced version of the dress stolen by Renate. This demonstrates that women's material desires can be fulfilled, but only when they are not individualised and are done in a collective manner for the benefit of all.

The socialist potential of all three female protagonists is underscored by the fact that Renate, Barbara and Anni are all single. According to Heineman, single women were closer to socialist emancipation than married women, because single women were more likely to be involved in the workforce. As such, single women workers could more easily identify with the class struggle and the inequalities created under capitalism (Heineman, 1999). This suggests that the socialist potential of Renate and Anni is greater simply because they are single. It also serves to emphasise Barbara's ideal qualities.

However, despite portraying these socialist ideals, and emphasising the benefits of the gender policies in East Germany, Dudow also questions the reality of these ideals. Although a lesser theme, there are several instances where the benefits and reality of gender equality are questioned. In one of the earliest scenes, a fellow law student of Barbara claims "I have nothing against women's rights. But..." his trailing off indicating not only a negative attitude towards equality, but possibly also the knowledge that such attitudes, while still held, are unacceptable (Dudow, 1952). ${ }^{32}$ In a further example, Barbara asks why there are so few female judges. Such statements question the socialist ideal and the reality of having achieved equality: clearly traditional gender attitudes still existed. Indeed, when the film was released, one critic even stated that the film showed

32 "Ich hab' nichts dagegen die Gleichberechtigung, aber..." 
that under socialism women can achieve "equality - without masculinisation" (qtd in Berghahn, 2005: 186), demonstrating that in spite of having 'equality,' women were still expected to maintain themselves in a particular manner. ${ }^{33}$ Despite being a minor theme in Frauenschicksale, the gap between gender ideals and gender realities would become a central theme in later DEFA women's films, including Der Dritte and Die Legende.

Through highlighting the degeneration and lasciviousness encouraged under capitalism, Frauenschicksale underscores the danger of women's sexual desires when un-tempered by collective responsibilities and socialist ideals. The notion of degeneration is epitomised in the character of Conny, and emphasised through his similarity to 'degenerate' populations from the Nazi era. On the other side of the scale are Barbara and Hertha, who represent the ideal socialist women, committed to the socialist cause and hard working. Indeed it was Barbara's adherence to socialism that saved her from the fate of Renate. However, both Renate and Anni are rescued from the degeneracy of capitalism by socialism. In doing so, socialism 'cures' these women of their sexual desires for Conny and their material desires. These depictions are all underscored with notions of socialist morality. The film's didactic mission impresses, primarily through the fate of Renate, the importance of socialist ideals for women: it is only through adherence to socialism, through employment and political awareness, that women can rise above their individual desires and lead a moral life.

\section{Kahlschlag}

Verwirrung der Liebe was released seven years after Frauenschicksale in 1959.

Meanwhile there had been little development in socialist morality and despite a brief

33 "Gleichberechtigung - und doch keine Vermännlichung!" 
period of cultural liberalisation in the early sixties, socialist morality and the image of the socialist person still guided cinematic depictions of daily life in the GDR. Women's sexual desires were still regulated by the sexually conservative values of socialist morality with the GDR's first marriage advice book, released in 1957, advocating traditional conceptions of women's sexual desires, placing women squarely in the role of mothers, even claiming that only once a woman had four to six children would her life be "varied, cheerful, complete" (Neubert qtd in Harsch, 2007: 134). Interestingly, Neubert's book also advocated premarital sex for young adults in loving relationships (qtd in Herzog, 2008: 74). Again, sexual desires were confined by socialist morality: only sexual desires that occurred in committed relationships were acceptable as these would lead to marriage and produce much needed offspring.

Despite attitudes towards women's sexual desires remaining unchanged, the SED's attitude towards material goods and consumption softened, largely due to unrest throughout the state. In the first Five-Year Plan, starting in 1950, the SED had the stated aim of ending rationing by 1953 at the latest (Pence, 2008: 290). However, the shortages continued, resulting in unrest. The State Commission for Trade and Supply, established in early 1953, attempted to address the concerns of East German consumers, but it did not prevent the worker's uprising of June 1953. The SED increased the production of consumer goods in an effort to quell discontent, showing no hesitation in manipulating the production of consumer goods to increase loyalty. Although rationing finally ended in 1958 , weakening the hard-line frugality of the immediate post-war era, consumerism was still gendered as a female domain. Because rationing had ended women were increasingly allowed to express their material desires in a variety of different ways. Still, 
this did not mean that they could be frivolous with their money; socialist morality maintained a firm foundation in non-materialism.

The early sixties brought with it a brief period of cultural liberalisation, in which films critical of the GDR that moved away from socialist morality were produced. With Stalin's death prior to the 1953 uprising, subsequent waves of de-Stalinisation efforts occurred throughout the Communist bloc and were made official by Khrushchev in 1956 when the Communist Party of the Soviet Union announced its official break with Stalinism. The impact of these de-Stalinisation policies in the GDR not only led to increased funding for consumer goods, but also to a cooling of censorship material and greater freedom in the cultural sphere. Somewhat counter-intuitively, both Joshua Feinstein and Daniela Berghahn cite the erection of the Berlin Wall in 1961 as safeguarding this cultural liberalisation. By physically containing the GDR from subversive western influences the cultural space of East Germany was able to grow. Quoting from DEFA director Kurt Maetzig, Berghahn cites, "after the erection of the Wall, the situation in the country stabilised and became calmer. We thought the time had come to tackle the problems in our country more critically and more outspokenly" (qtd in Berghahn, 2005: 143). ${ }^{34}$

However, this cultural liberalisation was only short-lived and came to an abrupt end in 1965 with the Eleventh Plenum and the re-assertion of socialist morality as a guiding framework for films. De-Stalinisation was only fleeting in East Germany, and certainly not as impressively undertaken as in other parts of Communist Eastern

\footnotetext{
34 "Nach dem Mauerbau kam es zu einer gewissen Beruhigung, Stabilisierung des Landes. Wir hielten den Zeitpunkt jetzt für gekommen, uns den inneren Problemen ohne Rücksichtnahme, kritisch und mit prinzipieller Deutlichkeit zu nähern."
} 
Europe. ${ }^{35}$ Given the ties between anti-fascism and the history of the SED as a Stalinist party, the process of de-Stalinisation was difficult for the SED to manoeuvre, for contesting Stalinism would mean contesting the anti-fascist origins of East Germany. The reluctance to readily adopt de-Stalinisation has been argued as contributing to a suppression of new cinematic styles of the time, such as an East German New Wave cinema (Berghahn, 2005: 170). Furthermore, the replacement of Khrushchev with Brezhnev in 1964 led to an abrupt end of de-Stalinisation and a backlash against the liberal reforms instituted in the years earlier. In the GDR, this backlash was most prominent in the Kahlschlag, a colloquial term for the events of the Eleventh Plenum of the SED in 1965. At this Plenum, twelve DEFA films were banned, several until the fall of the Berlin Wall in 1989. Many of these films were criticised on the basis of their representations of violence and sex, with Erich Honecker, who would later replace Walter Ulbricht as the General Secretary of the SED, claiming in his speech to the Politbüro that "Our GDR is a clean State," that was being led astray by the negative influence of West German television and radio, resulting in a growing "phenomenon of immorality and of a lifestyle foreign to socialism" in East German artworks (qtd in Schenk, 2006: 145-6). ${ }^{36}$ Honecker's invocation of cleanliness and morality is reminiscent of the 1958 "Ten Principles of Socialist Morality and Ethics" and indeed much of Honecker's criticism was the result of a backlash against the growing move away from the tenets of socialist morality. One of the films banned at the Plenum and specifically named by Honecker, Kurt Maetzig's Das Kaninchen bin ich (The Rabbit is Me, 1965) portrays a sexually suspect protagonist, who not only works in a bar, a site of

\footnotetext{
${ }^{35}$ For example, the workers' uprisings in Hungary and Poland.

${ }^{36}$ Although various art forms were criticised at the Eleventh Plenum, the film industry and DEFA were the particular focus of criticism and attack.
} 
degeneration, but, in a flashback the audience is shown losing her virginity as a teenager. Interestingly, the book upon which the film is based has the main character discuss her sexual desires and sexual partners, a theme that never makes it in to the film (Feinstein, 2002: 160). The banning of the film, along with the eleven others, clearly demonstrates the continued stranglehold on depictions of women's sexual desires, and their portrayal in popular culture.

The Kahlschlag had a devastating effect, fundamentally altering relationships between filmmakers and the state. It was the first experience of such wholesale censorship of art in the GDR. Not only were many films banned and some even destroyed, but the innovative aesthetics and critical depictions of East Germany and socialism, portrayed in many of the banned films were abandoned in future DEFA productions. It was not until Erich Honecker replaced Walter Ulbricht as the First Secretary of the Central Committee of the SED in 1971 that cultural policy in the GDR was again liberalised. This liberalisation resulted in more innovative aesthetics and critical depictions of daily life in East Germany, largely through focussing on the gap between socialist ideal and reality, possibly as a result of filmmakers experience with the Party at the Kahlschlag. While Frauenschicksale only cursorily addressed the conflict between socialist ideal and women's realities, through the remarks of Barbara and her colleagues, this would become a central theme in the popular culture of the early 1970s, in particular the two DEFA films Der Dritte and Die Legende analysed in the third chapter. These two films also examine the dichotomy between sexual and material desires in more detail, as well as presenting a more innovative aesthetic. 
Whereas under Ulbricht depictions of women and women's desires were based upon images of ideal socialist women, whose behaviour coincided with the expectations of socialist morality, like Barbara in Frauenschicksale, in the late 1960s Christa Wolf's novel Nachdenken über Christa $T$. began a trend that saw a movement away from socialist realism, towards more subjective depictions and stories that focused on questions of fulfillment and the tensions between the ideal and reality. As such, depictions of women moved away from the image of the proto-typical socialist towards more differentiated and 'real' characters, who like Wolf's Christa T and Margit and Paula from Der Dritte and Die Legende respectively, were outsiders, not quite fitting within the norms of East German society.

The move to such differentiated depictions of women was the result of social and political developments in the GDR, largely coming as the result of the change in leadership from Ulbricht to Honecker in 1971. The liberalisation of cultural policy was one of many developments in social policy introduced under Honecker, including a relaxation of socialist morality. Despite the fact that women's sexual desires were strictly controlled by socialist morality throughout the fifties and sixties, by the time Honecker gained power women were able to desire more freely. Such relaxation in the area of regulating women's sexual desires was also reflected in the cinema and both Der Dritte and Die Legende feature sexually assertive female protagonists. However, consumerism was still viewed as a feminine domain and material desires were depicted as a female vice. The liberalisation that occurred in the seventies under Honecker was not solely the result of this leadership change. Changing societal values and norms prompted the need for reform and a review of the prudish morality imposed under 
Ulbricht. How the changing societal values brought about the liberalisation of the seventies and affected the regulation of women's sexual and material desires, and their depiction in East German cinema of the early seventies is the subject of the coming chapter. It is argued that just as the socialist personality and socialist morality grew out of the needs of the post-war consolidation of socialist rule, leading female protagonists in Gegenwartsfilme to be used as didactic figures, instructing East German women on socialist ideals, the societal and political changes arising in the early Honecker era necessitated the move away from idealised depictions of women to ones that were more realistic and critical, where female characters were instrumentalised as metaphors for greater societal concerns. 


\section{The Difficulty of Saying ' $I$ '}

So there she was, walking along in front, stalking head-in-air along the curb, and suddenly she put a rolled newspaper to her mouth and let go with her shout: HOOOHAAHOOO - something like that (Wolf, 1970: 9)

Between the release of Frauenschicksale in 1952 and Der Dritte and Die Legende some twenty years later, much had changed in terms of the kinds of images and themes East German directors could use in depicting women. Rather than portray idealised socialist women based upon norms of socialist morality, cinematic depictions of women moved towards more realistic female protagonists who were largely critical of the State. Relieved of the shackles of socialist morality, Der Dritte and Die Legende both feature portrayals of promiscuous sexual relationships, and Die Legende even features a nude scene, standing in stark contrast to the sexually conservative depiction of relationships in Frauenschicksale and the controversy surrounding nudity in Verwirrung der Liebe. The didactic impulse of socialist realism in the fifties to instruct viewers on the correct mode of behaviour had ceased to define the portrayals of daily life in Gegenwartsfilme of the seventies.

But, how did these changes come about? Why did socialist morality loosen, and why was there a move away from socialist realism? This chapter examines the societal developments occurring in East Germany that enabled the radical change in the depiction of women and women's desires from Frauenschicksale to Der Dritte and Die Legende. This task involves not only examining how depictions of women and desires were changing in the intervening period between Frauenschicksale and Der Dritte, but also how changing social and political conditions led to a different instrumentalisation of female protagonists. 
One of the difficulties when tracing the evolution in the depiction of women and desires from Frauenschicksale (and even Verwirrung der Liebe) to Der Dritte and Die Legende is the surprising dearth of Gegenwartsfilme from the mid-sixties featuring a female protagonist. The censorship brought about by the 1965 Eleventh Plenum meant that for the latter half of the sixties films presenting life in the GDR in a "nonconventional fashion," through using more innovative aesthetics or depicting protagonists who did not comply with the norms of socialist realism, were unsuccessful (Feinstein, 2002: 197). As such, portrayals of women maintained the socialist realist tenet of portraying positive model socialist heroines (Rinke, 2006: 7).

East German women's literature from the late sixties, meanwhile, does give some indication of the developments occurring in the GDR, with regard to gender roles, specifically the depiction of women's desires and the move away from socialist realism. Furthermore, many of the changes that occurred in the mid to late 1960s in women's writing not only echoed the developments in East German cinema prior to the Eleventh Plenum, but would foreshadow many of the elements of Frauenfilme from the seventies and eighties. It is for this reason that the central focus of this chapter is Christa Wolf's novel Nachdenken über Christa T. as a bridge between the portrayal of women in Frauenschicksale and those of Der Dritte and Die Legende. Wolf's text marks a point of departure for depictions of women and will be the main subject of analysis. In terms of cinema, Nachdenken über Christa T. is a consummate example of the aesthetic and thematic changes that would occur in cinema in the early seventies. Not only does it employ a non-socialist realist style, but by appropriating the narrative voice along with themes of ideal and reality, Nachdenken über Christa T. highlights women's desire for 
self-determination and fulfillment. While the text does not explicitly deal with sexual or material desires, in Der Dritte and Die Legende the themes of self-determination and fulfillment arise in guiding the female protagonists to use either sexual relationships or material desires as a vehicle through which to obtain happiness. In both Nachdenken über Christa T. and the two films analysed in the third chapter it is the inability of the female protagonists to achieve this fulfillment that houses the most trenchant critique of real existing socialism.

The development of a subjective voice and a new aesthetic in Wolf's writing are symptomatic of a more fundamental change occurring throughout GDR society in the late sixties, namely, the growing dissatisfaction with the utopian discourses disseminated under Ulbricht. This dissatisfaction led to an aesthetic called Utopieverlust, or loss of utopia, where themes began to centre on expressing the loss of utopian aspirations and critically examining the failure of the socialist project. As such, critical depictions of life under socialism became increasingly prevalent in the early seventies, further encouraged by the liberalisation of cultural policy under Honecker. Nachdenken über Christa T., Der Dritte and Die Legende are all examples of this trend. Whereas the depiction of women's desires in Frauenschicksale coincided with the pronouncements of the SED, Der Dritte and Die Legende used women's desires as a device to criticise socialism, and expose the gap between ideal and reality.

This chapter begins with an analysis of Christa Wolf's Nachdenken über Christa $T$., and the manner in which it foreshadowed the changes that would occur in cinematic depictions of women and their desires. It then moves into a discussion of the changes brought about by Honecker's ascension to power that influenced women's ability to 
desire and the portrayal of these desires, before concluding with an analysis of the trends occurring in the cinema of the seventies and eighties. It argues that the developments in depictions of women, exemplified in Nachdenken über Christa T., alongside the societal and political changes occurring in the early seventies led filmmakers to instrumentalise female protagonists as symbols of greater societal discontent and as providing an alternative form of socialism in contrast to the patriarchy of the SED. In turn this led to more critical and less idealised portrayals of women and women's desires. These changes were made possible through Wolf's appropriation of the narrative voice and her assertion of women as subjective beings, capable of critical thinking, which stood in stark contrast to the socialist realist portrayals of women in the fifties.

\section{Nachdenken über Christa T. (The Quest for Christa T)}

The guiding rhetoric of the SED in the 1950s and 1960s was that of building a future socialist utopia, the argument being, that while the people may have to go without today, they were working to create a better tomorrow. This vision of "making everything different" was particularly salient in the post-war era, when people suffered from hunger and needed shelter (Becker, 2000: 8). ${ }^{37}$ Furthermore, within the context of the Cold War, the notion of working towards utopia gave the SED a moral legitimacy with the people: although they had not been elected, and standards of living in the East were lower than in the West, the SED worked towards making life better for all (Ibid: 7). Part of this discourse was the concept of a wissenschaftliche-technische Revolution (scientific-technical revolution) meaning that it was the implementation of scientific developments in industry that would result in revolution, precipitating a rapid increase in

37 "Alles-ganz-anders-Machen" 
output and a transformation of life through the creation of a communist utopia. The SED believed that socialism was the only system capable of exploiting the revolutionary capabilities of science and that the revolution would demonstrate the superiority of socialism (McCauley, 1983: 127).

However, by the mid to late sixties, when the gap between life in East and West Germany was glaringly obvious even after twenty years of working towards a communist utopia that had not been created, the promise of a different and better life in the future had lost its cohesive social force (Becker, 2000: 8). Furthermore, there had been no scientific-technical revolution, and the promotion of science had only increased class differences, with greater disparities between those workers with technical or scientific knowledge and those without (McCauley, 1983: 156). The growing disillusionment with socialism was reinforced by the events of the Prague Spring in 1968, where Soviet tanks invaded Czechoslovakia in order to quell the reforms introduced by leader Alexander Dubček, forcing many East German intellectuals to come to terms with the repressive direction of socialism. The loss of the force of this utopian discourse was initially reflected in changes in the cultural sphere. Artists, many of whom were committed socialists and believed in socialist values and ideals, were mourning the loss of their hopes for East Germany; feelings that were only strengthened by the treatment of artists, in particular filmmakers, in the Kahlschlag of 1965.

Christa Wolf's ideological and artistic developments reflect these changes. Born Christa Ihlenfeld in 1929 in Landsberg an der Warthe, a city that, post-1945, would come to belong to Poland. Expelled at war's end, Wolf's family settled in Mecklenburg in East Germany. At the beginning of her career, Wolf embodied the socialist ideal; a 
committed Party member since 1949, Wolf firmly believed in socialism's potential to produce real change in people (Kuhn, 1988:30). In her essay "Conditions on a Narrative," published in Kassandra (Cassandra, 1983), Wolf describes her discovery of Marxism as a "liberating and illuminating experience" particularly coming out of the horrors of World War II and the Holocaust (1984: 278). By her own admission, she initially failed to critically see the difference between socialist theory and practice, leading her to unquestioningly accept SED dogma (Kuhn, 1988: 20). Her first text Moskauer Novelle (Moscow Novella, 1961) obediently followed the norms of socialist realism, even presenting a similar message to Dudow's Frauenschicksale, namely, that the needs of the collective must come before individual desires. ${ }^{38}$ Wolf was even a candidate for the Central Committee of the SED following the publication of her second novel, the Bitterfeld text Der Geteilte Himmel (The Divided Heaven, 1963). ${ }^{39}$ Also during this time, more precisely between 1959 and 1962, Wolf collaborated with the Stasi. However, her critical involvement in the Eleventh Plenum of 1965 led to her removal as an SED candidate (Hell, 1997: 138).

Around the time she moved to Halle in 1963 Wolf began to think more critically about the Party and the need for open political discussion, leading to her to write Nachdenken über Christa T. (Ibid; Love, 1991: 68). Her discussions on Stalinism with

\footnotetext{
${ }^{38}$ Moskauer Novelle presents the story of Vera Bauer, a young East German doctor, who is sent in a delegation to Moscow. There, she is met by Russian translator Pawel Koschkin, a man she had earlier met, and loved, as a soldier during the Red Army occupation of her village. Despite both being married, their love is rekindled during Vera's stay in Moscow. Although tempted by her feelings, Vera returns to her husband in East Germany, and encourages Pawel to return to his wife and take up a teaching position in the east. As noted by Kuhn, "it is not respect for the institution of marriage but the need for both to be productive members of their respective societies that causes the lovers to separate" (Kuhn, 1988: 21). ${ }^{39}$ At the Bitterfeld Conference of 1959, the SED encouraged writers and artists to go to the factories and gain practical work experiences, thus enabling them to portray the collective more believably. From 1959 to 1962 , Wolf lived in Halle, working in a brigade at the railroad car works. Der Geteilte Himmel was produced out of her experiences in this brigade (Kuhn, 1988: 27). Interestingly, the artist Sonja in Verwirrung der Liebe is also seen taking part in the Bitterfeld movement, leaving her art education to gain practical experience working in a textile factory, where she is seen drawing her fellow workers.
} 
Walter Janka and Friedrich Schlotterbeck, both victims of the purges occurring throughout the GDR in the late 1940s, led her to question her loyalty to the SED (Hell, 1997: 138).$^{40}$ It is at this point, when Wolf was examining socialist life in the GDR more critically, that she wrote Nachdenken über Christa T. a text so controversial that it was almost banned by the SED. Wolf described the severe criticism she faced on its publication in 1968 as the "key moment in her growing critical distance from the SED and its state," thus making the novel a "breakthrough of sadness" (qtd in ibid: 139).

This invocation of sadness hints at the grief felt by Wolf at the loss of her socialist utopian dream: the mourning of which would be portrayed in Nachdenken über Christa T. and has been labelled by academics as an aesthetic of Utopieverlust. Rather than use the notion of utopia as a yardstick to measure life in the GDR, and to encourage individuals to adhere to socialist norms, beginning in the mid to late sixties and increasingly throughout the seventies, artists portrayed themes mourning the loss of socialist aspirations (Feinstein, 1999: 206). ${ }^{41}$ Central to this mourning was a concern with the disparity between the ideals of socialism and the reality of life in East Germany. In 1963, in a statement to a student newspaper Wolf posited:

The main problem of many young people is (and will remain) the tension between ideal and reality, between their expectations of happiness and the fulfillment of those expectations, the contradiction between the...possibilities which we already have and their often imperfect realization through all of us (qtd in Kuhn, 1988: 42)

\footnotetext{
${ }^{40}$ Interestingly, Walter Janka had served on the DEFA board for three months in 1948, before being ousted and replaced by loyal SED members (Allan, 1999: 6).

${ }^{41}$ Joshua Feinstein has argued that earlier artworks, such as Frank Beyer's film Spur der Steine (Trail of Stones, 1966) "explicitly questioned the regime's millennialism...and perhaps even helped to channel shifts in official ideology that occurred in East German, and elsewhere following the collapse of reform efforts during the late sixties [sic]." (Feinstein, 1999: 206) Although he raises a pertinent point, this area of study is outside the scope of this thesis.
} 
Indeed, this theme would not only be the focus of Nachdenken über Christa T., but also the dominant concern of films throughout the seventies and eighties, including Der Dritte and Die Legende.

In many ways Nachdenken über Christa $T$. foreshadows the developments that would occur in depictions of women in East German cinema from the seventies. Firstly, Nachdenken über Christa T. is one of the earliest departures from socialist realism, and, as mentioned above, the novel highlights a thematic concern with the tension between the ideal and reality and the location of the individual and role of self-fulfillment within the reality of socialist practice. In addressing socialist ideals and how they compare to socialist practice in East Germany, Wolf's text was highly critical of the SED, particularly in comparison to the socialist realist depictions of her earlier work. Furthermore, her depiction of women exemplifies the move away from ideal socialist heroines towards depictions of women who stand outside the expected norms of East German society. Each of these four areas would be taken up by directors, and are evidenced in Der Dritte and Die Legende, where both films use the protagonists' desire for happiness, through either sexual or material fulfillment, as a mechanism to examine the gap between ideal and reality in order to critique the way in which East German society moderated women's behaviour through either an unquestioning adherence to socialism or the persistence of traditional gender norms.

The main mechanism through which Wolf departs from socialist realism is her appropriation of the narrative voice; a style she had dubbed "subjective authenticity" (qtd in Kaufmann, 1989: 60). With this, Wolf was intending to speak from her own subjective experience as a woman (and a writer, a Marxist etc). Rather than merely 
replicate external reality through accuracy of description, Wolf sought to appropriate reality, by engaging her own subjective experience with that reality (Kuhn, 1988: 55). It was important for Wolf that "behind all the fiction and illusion one can hear the author's voice and see his face" (Wolf qtd in Hell, 1997: 140). In order to do this, however, Wolf needed to fundamentally reject the basic precepts of socialist realism. In a 1973 interview with Hans Kaufmann, Wolf argued that in using the term "authenticity" she did not mean "truthfulness" in a moralising sense, but rather that in writing from her experience she was presenting her own truth (Wolf qtd in Kaufmann, 1989: 60). This statement plays upon the tenets of socialist realism established at the 1934 Congress of the Soviet Writers' Union, where the didactic purpose of literature was created through a "truthful presentation of real life" that was aimed at assisting people's socialist education and transformation (qtd in Kuhn, 1988: 9). Frauenschicksale is an apt example of the didactic function of art; through presenting a moral tale of the dangers of desire, Dudow was showing women how they should behave. This kind of moralistic truth, pushed in socialist realism, is explicitly rejected by Wolf.

The self-reflection and introspection encouraged in Wolf's "subjective authenticity" also defied socialist realist expectations. Written from the first-person perspective of the narrator, Nachdenken über Christa T. is the narrator's reflection on her friendship with Christa T. Upon learning of the death of Christa, the narrator attempts to reconstruct Christa T's life through her own recollections, as well as the writings of Christa $\mathrm{T}$ herself. The self-reflection and personal exploration encountered as the narrator re-discovers her memories of Christa comes at the expense of a more plot-driven narrative. Plot, according to Wolf, had the potential to be "an obstacle to creating 
precisely that inner authenticity" (qtd in Kaufmann, 1989: 59). Not only did this mark Nachdenken über Christa T. as one of the first East German modernist texts, but also distinguished it from the expectation in socialist realism that a text be firmly based in the world of work and industrial production, rather than the private sphere (Kuhn, 1988: 9). Similarly, in presenting the character of Christa, a non-conforming outsider, Wolf was further rejecting the socialist realist norm that only positive socialist heroes, like Barbara in Frauenschicksale should be portrayed (Ibid).

In discussing her use of "subjective authenticity" Wolf described it in terms of something she was compelled to do: "It becomes more and more difficult to say 'I', and yet at the same time often imperative to do so" (qtd in Kaufmann, 1989: 60). This need to say 'I' and appropriate her own reality, through requisitioning the narrative voice, serves to emphasise the author's (and narrator's) need for self-fulfillment through selfactualisation. Indeed, self-actualisation is established as a leitmotif at the beginning of the text with a quote from Johannes R. Becher: "This coming-to-oneself - what is it?" (qtd in Wolf, 1970). Wolf's quotation of Becher not only establishes self-fulfillment as a motif, but also sets a critical tone. Johannes R. Becher was an important SED member, not only writing the lyrics to the East German national anthem, but also acting as the Minister of Culture between 1954 and 1958. Given the novel's focus on the failure of socialist reality to match the ideals of self-fulfillment and actualisation, in quoting Becher Wolf is suggesting that within the SED there is an institutionalised failure to understand the importance of self-fulfillment and self-expression.

The critique of the implementation of socialist ideals in East German daily life is undertaken on two levels. Firstly, Christa T's spontaneous self-determination stands in 
contrast to the expected modes of behaviour of women under socialism, like those depicted in Gegenwartsfilme from the fifties and sixties. This is most aptly demonstrated in the quote opening this chapter. The scene takes place at the beginning of the friendship between the narrator and Christa T. The narrator, at the time a young girl, observes Christa make a trumpet out of a rolled up newspaper and shout "HOOOHAAHOOO" (Ibid: 9): a rebellious act of individual expression that contrasts to the expected behaviour of the ideal socialist person. As an adult, the narrator reflects that "never, never again did I want to stand outside the town park, outside the fencedin deer meadow, on a day without any sunshine - and it was another person who'd let go with that shout which erased everything and for a fraction of a second lifted the sky up high" (Ibid: 10)

From this it is clear that the narrator longs to be as free as Christa, to be able to break out from the confines of the socialist expectation of how girls should act and express her individuality that she is expected to subordinate to the collective. These feelings are emphasised by her admission that she longed "to share in a life that produced such shouts as her hooohaahooo" (Ibid: 11). Furthermore, Wolf intimates the danger of socialism in repressing this individuality, with the narrator reflecting: "suddenly I felt, with a sense of terror, that you'll come to a bad end if you suppress all the shouts prematurely" (Ibid).

Secondly, the novel critiques the East German socialist project by problematising the enactment of socialist ideals through the character of Christa T. Despite being a committed socialist, Christa $\mathrm{T}$ is an outsider, whose non-conformism is not tolerated in East German society. As pointed out by Myra Love, it is Christa T's strong relationship to the aims of socialism that makes her very existence problematic (Love, 1991:71). In the early years of consolidation of the socialist regime in East Germany the focus was on 
improving industrial production, rather than on the creation of new social relationships (Ibid). While Christa's search for knowledge and personal development may align with the Marxist ideal of self-actualisation, it did not coincide with the conditions prevailing in East Germany at the time. In this manner Wolf is criticising the implementation (or rather, lack thereof) of socialist ideals in East Germany. Christa $\mathrm{T}$ comes to serve as a reminder that socialism is more than nationalisation, rationalisation, and industrialisation. Christ $\mathrm{T}$. is to serve as an incentive to question the indefinite postponement of the more important activity of establishing qualitatively new social relations (Ibid)

This reminder, however, was unwanted in an East Germany focused on industrial production and catching up economically with the West.

Despite being labelled as Utopieverlust, in many ways Nachdenken über Christa $T$. can be viewed as utopian in its appeal to the ideals of socialist self-actualisation. Marx, in The German Ideology calls for individuals to appropriate their productive forces, in order to achieve self-activity, or self-actualisation (1968: 84). As a writer, Wolf appropriated her productive force by writing from her subjective experiences, an act also reflected in Nachdenken über Christa T., where Christa $\mathbf{T}$ is attempting to write "The Big Hope, or, The Difficulty of Saying 'I"' (Wolf, 1970: 169). However, the death of Christa $\mathrm{T}$ demonstrates a tacit understanding that such idealism cannot exist in the GDR; Wolf is thus questioning the extent to which socialism has actually been implemented in East Germany. Such fundamental questions highlight a sense of loss or mourning at what socialism in East Germany could have been and allows for the description of the text as Utopieverlust. This loss is only confirmed by the critical reaction to the text and Wolf's aforementioned description of Nachdenken über Christa T. as a "breakthrough of sadness" (qtd in Hell, 1997: 139). 
In spite of this, Nachdenken über Christa T. was of fundamental importance to the establishment of subjective female voice in the GDR. With Nachdenken über Christa T. Wolf asserted women as subjective beings, wedging more of a role in society for women and their experiences as women. In doing so, Wolf gave women a role in shaping how they themselves were depicted. This led to more subjective and realistic portrayals of critical heroines in the seventies, including an increase in 'protocol' collections, such as Maxie Wander's Guten Morgen, du Schöne (Good Morning, Beautiful, 1978) where Wander interviewed various East German women and retold their stories in a first person narrative. Setting out from the subjectivisation of women's voices that started with Nachdenken über Christa T., Wander's collection of interviews "made an important contribution to identity politics in the GDR, carving out a female subject position that challenged the ostensibly gender-neutral concept of the socialist New Man, embodied by the worker-hero" (Sieg, 1995: 112).

The subjectivisation of female voices in Nachdenken über Christa T. also occurred in GDR cinema, where more ordinary and realistic female protagonists were presented beginning in the early seventies. Unlike the proto-typical heroine Barbara from Frauenschicksale, heroines of Gegenwartsfilme from the seventies and eighties were often single mothers, working in low-skilled manual jobs, coinciding with the actual position of women in the GDR. Furthermore, these heroines' desires no longer coincided with socialist morality. Similarly, Wolf's thematic preoccupation with selfactualisation and fulfillment, alongside questions of socialist ideal and reality, brought about by the loss of utopian socialist aspirations, would come to be a dominant trend in the cinema of the seventies and eighties, and indeed there are many parallels between 
Nachdenken über Christa T. and the portrayals of women's desires in Die Legende and to a lesser extent Der Dritte. These cinematic developments were enabled by liberalising social and political changes that allowed films to become more critical and experiment with new aesthetics and encouraged an individualised approach socialism, in contrast to the collective impulse of the fifties.

\section{From Ulbricht to Honecker}

The manner in which Nachdenken über Christa T. established a subjective voice for women was reflected at the societal level, where women (and men) were increasingly treated as autonomous individuals, more freely allowed to desire and express their individuality. Soon after the publication of Nachdenken über Christa T. socialist morality and the socialist personality began to loosen as a concept governing how women behaved. Furthermore, many policies were introduced that aimed at reconciling women's domestic roles with their public lives. These changes were all depicted in the Gegenwartsfilme of the seventies, where more individualised and 'real' heroines are portrayed. However, in spite of a loosening of socialist morality, women's desires were still confined by a persisting and institutionalised patriarchy evident in policies that reinforced women's role as the primary caregiver. Importantly, this patriarchy allowed filmmakers to instrumentalise female protagonists as symbols of greater societal discontent and construct a female alternative to the SED regime.

Of key importance to these developments was the change in leadership from Walter Ulbricht to Erich Honecker in 1971, and the corresponding change in state rhetoric which allowed for greater focus on the individual. In many ways Wolf's 
Utopieverlust aesthetic was symptomatic of a malaise coming over East Germany in the late sixties. The focus on industrial production, which by 1969 in East Germany had surpassed the output of the German Reich in 1936, had come at the expense of the production of consumer goods (McCauley, 1983: 144). Furthermore, the sexually conservative and authoritarian control of sexuality via socialist morality was increasingly out of step with the reality of sexual practices in East Germany. The danger of ignoring the citizenry's needs was illustrated in the 1970 Polish protests, arising in response to high food prices and resulting in military intervention (Ibid). If the SED wanted to maintain control such social problems needed to be addressed: people could not live on promises of a future utopia when facing a lack of consumer goods, a shortage of housing and a lower standard of living than in the West. The change in leadership at the Sixteenth Plenum of the Central Committee of the SED on 3 May 1971 provided the prime opportunity to address the material needs of the East Germany citizenry and to update their sexual policies and rhetoric.

At the heart of many of the policy changes enacted under Honecker was a change in Party rhetoric, which enabled a focus on the individual and the need for selffulfillment, not only echoing Nachdenken über Christa T., but also corresponding to the protagonists' quests for self-fulfillment in Der Dritte and Die Legende. By the time Honecker reached power, the regime no longer discussed the attainment of communism as being a goal attainable in the near future, with Honecker stating at the Eighth Party Congress that "it is clear that it will be sometime, and much remains to be done, before we can say that Socialism has been completed in the German Democratic Republic" (1972: 24). Similarly, the concept of the "scientific-technical revolution" was replaced 
with "scientific-technical progress" to emphasise the on-going nature of social transformation. The underlying development allowing for this approach was the move to what was characterized as the pursuit of real-existierender sozialismus (real existing socialism). This concept focused on socialism as it actually was practiced, rather than what it could be in the future. This allowed the present day needs and happiness of the individual to take precedence over the collective; representing a fundamental change in the conceptualisation and practice of socialism in East Germany that had previously focused on notions of a future utopia and the importance of industrial production. The importance of the individual to socialism was first expressed at the Eighth Party Congress, held in 1971, where Honecker announced that we are guided by only one objective, which permeates the entire policy of our party: to do everything possible for the wellbeing of man, for the happiness of the people, for the interests of the working class and all working people. That is the meaning of Socialism. (Ibid: 5)

The shift of focus to the individual indicated in Honecker's speech echoes Christa Wolf's call for self-actualisation in Nachdenken über Christa T. and is reiterated by Feinstein who states that under Honecker there was a "call for a society dedicated to personal self-realization;" a call emphasised in the phrase found in the East German Constitution - "The individual is the focus" (Feinstein, 2002: 201).

While the advances made in women's literature in the late sixties, exemplified in Nachdenken über Christa T., laid the groundwork for the changes that would occur in cinematic depictions of women, it was through the new policies enacted under Honecker that they were cemented. The move to real-existing socialism forced the renegotiation of many of the policies driving the Ulbricht era. The urgency to forge new anti-fascist socialist citizens dissipated, the reins of socialist morality were loosened, social policy 
was reinvigorated, particularly in the field of Frauenpolitik and there was an increased focus on the production of consumer goods. Perhaps most importantly, there was a much-needed liberalisation of cultural policy, freeing filmmakers from the shackles of the Kahlschlag. Each of these developments were nurtured by the cooling of Cold War tensions in the era of détente and impacted both on the way women were able to desire and on the manner in which these desires were depicted.

Most importantly, it was the growth of social policy and the increase in focus on material well being that encouraged and reinforced an individualistic attitude amongst East Germans in the seventies (Egighian, 2008: 55). In turn this led to the loosening of the authoritarian concept of the 'new man,' as a set of idealised traits based on socialist norms. As such, cinematic depictions of women began to move away from idealised socialist heroines, paralleling Christa T's non-conformism in Nachdenken über Christa $T$. Indeed, there is a shift away from socialist norms towards the boundary of East German society from Christa $\mathrm{T}$ in Nachdenken über Christa T. and Margit in Der Dritte to Paula in Die Legende. Given that twenty-six years had passed since the end of World War II, and that socialism was well established in East Germany, the pressing need to create citizens opposed to fascism and committed to socialism no longer existed. ${ }^{42}$ As such, didactic films like those of the fifties were no longer needed to instruct East German women on how they should behave.

However, the societal shift towards individualism brought with it new challenges in the socialist regulation of personality, in particular how the state should motivate adherence to socialist values and prevent anti-social behaviour (Egighian, 2004: 191).

\footnotetext{
${ }^{42}$ Historian Mary Fulbrook has labelled the period between 1972 and 1989 as the 'established phase' in the histories of the two German states, although she does note that this establishment was "by no means static" (Fulbrook, 2000: 23)
} 
Consequently there was an increase in research in the field of forensic psychology, which resulted in greater state surveillance up to the early eighties, so although there was greater room in which individuals could negotiate the private and public sphere, dissent was not tolerated (Ibid; Egighian, 2008: 154). Therefore, although there was more room for spontaneity and individuality, women were still expected to be full time workers, mothers and politically active.

These changes to the socialist personality and socialist morality were enormously important for the regulation and depiction of women's sexual desires. Whereas in the 1950s and 1960s premarital sex was viewed as acceptable providing that it took place within a committed relationship leading to marriage, by the early 1970s the SED was encouraging uncommitted heterosexual relationships (Herzog, 2005: 187). Furthermore, the Termination of Pregnancy Act, enacted in 1972, gave women the right to obtain first trimester abortions and free access to the oral contraceptive pill. These developments were the result of empirical studies conducted in the 1960s indicating the level and nature of youth sexuality and highlighting the problems of illegal abortions and youthful divorces (Ibid: 187, 200). Not to be discounted was the work undertaken by liberal sexologists, such as Lykke Aresin and Karl-Heinz Mehlan, who were active in the field of reproductive rights. The loosening of socialist morality allowed women to enter into uncommitted sexual relationships, without official morality deeming such behaviour as immoral, un-socialist and subversive. Furthermore, through giving women access to their reproductive rights through the decriminalisation of abortion and access to the contraceptive pill, women were given more freedom in their sexual practices. This freedom was relished by women, and as argued by Herzog sex became a "crucial free 
space" in which women could negotiate power (Ibid: 188). The power that women had in sexual relationships in East Germany is clearly demonstrated in the cinema of the seventies and eighties, including Der Dritte and Die Legende. While women may have been oppressed or regulated through various mechanisms, be it socialism, traditional gender roles or lack of resources, they are consistently portrayed as sexually assertive. As an example, while Margit from Der Dritte is portrayed as being pressured by gender norms that expect her to be a passive romantic subject, she takes no issue with kicking her anonymous lover out of bed at the beginning of the film.

The manner in which Nachdenken über Christa T. created a space for subjective and 'real' female characters in art was reflected in the increase in social policies in the area of Frauenpolitik and the increase in the production of consumer goods. These policies arose out of the move to real-existing socialism and its complementary focus on the material well-being of the individual and they seemingly respected the reality of women's lives through aiming at easing their double burden. However, despite allowing women to desire more freely through relaxing socialist morality, and introducing policies that enabled women to embrace both their public and private roles, an underlying patriarchy continued to regulate women's roles and desires throughout the seventies and eighties. This is clearly demonstrated in the 1971 Five-Year Plan. In the section addressing women's equality in the Plan, Honecker states "We truly appreciate the selfconfidence with which they [women] also solve the hundred and one apparently small problems they are faced with every day in the household and family" (1972: 43). This somewhat condescending remark illustrates a tacit acceptance of women's roles as primarily located within the domestic sphere and fundamentally linked to providing for 
the well-being of the family; a truth even acknowledged by Honecker who stated further on "without underestimating the increasing cooperation of men in the household...the main burden is borne by the women" (Ibid). Indeed, the social policies that arose out of this Plan that were aimed at easing women's double burden (e.g. Household Day, extended maternity leave) only served to emphasise women's domestic roles. Similarly, given the continued gendering of consumption, the increase in the production of consumer goods was as much about easing women's double burden of paid work and household duties as the Household Day. The fact that such traditionally gendered ideas of women's roles continued to exist in East Germany into the seventies is evidence of a persisting patriarchy that prevented women from gaining full access to their legal equality. What this implies in terms of women's desires (both material and sexual) is that although they were freer to desire and behave outside of the expected norms of socialist morality, they could not behave in a manner that would detract from their domestic role.

The existence of such a patriarchy in a supposedly gender equal state points to the conflict between ideal and reality that was posed by Wolf in Nachdenken über Christa T. Ideal and reality would come to be the dominant theme presented in Gegenwartsfilme of the seventies and eighties and both Der Dritte and Die Legende closely examine the manner in which socialist reality lives up to the hopes and dreams of the female protagonists. The cinematic concern with ideal and reality is affirmed by Rinke, who stated in her analysis of East German Frauenfilme from the 1970s and 1980 s, that during the early seventies films

often critically addressed the discrepancies between the ideal and reality, between new opportunities the socialist state offered women, as well as outdated attitudes 
that prevented men and women from taking advantage of societal breakthroughs (1998: 209)

Indeed one of the "outdated attitudes" that films used was the traditional gendered thinking that circumscribed consumption to women, and reinforced women's domestic roles. In doing so, they critically addressed the failure of the socialist regime to create a truly gender equal society, as they purported to have done.

The essential factor that allowed these critical depictions to be produced was the liberalisation of cultural policy created in the early years of Honecker's rule. This liberalisation was introduced by Honecker at the Fourth Conference of the Central Committee of the SED in December 1971 and permitted increased innovation throughout the arts, including a move away from socialist realist aesthetics and more critical portrayals of life under socialism. At this conference, Honecker announced that:

If one starts from a firm socialist standpoint, there cannot, in my opinion, be any taboo subject for art and literature. This concerns questions of both content and style - in short: all issues relating to artistic mastery (qtd in Rü $\beta, 1976: 287)^{43}$

With this, Honecker ended the restrictive cultural atmosphere created at the 1965 Eleventh Plenum, further emphasised by the release of two films banned under Ulbricht: Der verlorene Engel (The Lost Angel) banned in 1966 and Sonnensucher (Sun Seekers) banned in 1958 (Rinke, 2006: 39). In terms of cinema, directors were able to return to the developments that were occurring in cinema prior to 1965 and were taken over by women's literature and Christa Wolf in the wake of the Kahlschlag. Films began to increasingly focus on the everyday experience of socialism in East Germany, which was encouraged by Honecker at the Eighth Party Congress, where he stated that the Party

\footnotetext{
43 "Wenn man von der festen Position des Sozialismus ausgeht, kann es meines Erachtens auf dem Gebiet von Kunst und Literatur keine Tabus geben. Das betrifft sowohl die Fragen der inhaltlichen Gestaltung als auch des Stils - kurz gesagt: die Fragen dessen, was man die künstlerische Meisterschaft nennt"
} 
would stand behind depictions of "the great and world-changing deeds in the everyday dealings of people under socialism" (qtd in Rüß, 1976: 180). ${ }^{44}$

Despite the liberalisation of cultural policy, filmmakers still needed to encode more critical messages in order to escape censorship. One of the coding techniques used by DEFA filmmakers was the instrumentalisation of female characters as metaphors for greater societal discontent. This mechanism relied on patriarchal attitudes that would dismiss women's voices, as well as classical Marxist views on the role women played in socialism. Women's emancipation served as an indicator of the success of the socialist project, and as such heroines often stood for the possibilities of socialist progress (Mihan qtd in Rinke, 1998: 209). ${ }^{45}$ Reading Frauenfilme in this manner gives a symbolic purpose to the actions of the female protagonists: women in East German cinema were not only women, but stood for the potential of East German society under socialism, leading Andrea Rinke to comment that Frauenfilme were "seismographs of the condition of society" (Ibid). Supporting this is Regina Kühn, a DEFA scriptwriter, who explained that:

Female characters were often depicted in films during this time, not in order to depict women, but rather, it was because it was possible to discuss everyday problems, that were on the border of what one was allowed to discuss, when women were depicted, because: women are always allowed to be a little more crazy, more imaginative, more fanatical, poorer, thinner, to be a everything a little bit more than men (qtd in Frauenbilder, 1997: 8)

\footnotetext{
44 "in den alltäglichen Handlungen der Menschen im Sozialismus die großen und weltverändernden Taten" 45 "Heldinnen stehen stellvertretend für die Entwicklungsmöglichkeiten des Menschen im Sozialismus überhaupt"

${ }^{46}$ Frauenfiguren wurden in dieser Zeit oftmals erzählt in Filmen, nicht um Frauenfiguren zu erzählen, sondern weil es möglich war, Gegenwartsprobleme, die an die Grenze dessen gingen, was man uns erlaubt hat, zu erzählen, oftmals leichter durchzusetzen waren, wenn man sie anhand von Frauen erzählt hat, weil: Frauen durften immer ein bisschen verrückter, ein bisschen phantasievoller, ein bisschen ausgeflippter, ein bisschen ärmer, ein bisschen magerer, ein bisschen alles-ein-bisschen-mehr sein als Männer.
} 
Therefore, by playing upon the traditional gender norms that existed at the state level, linking women to emotional excess and the domestic world of the everyday, directors could instrumentalise female characters to discuss issues of greater societal significance and avoid the censorship of the socialist regime. ${ }^{47}$ By using female characters in this manner, the filmmakers were ironically underscoring the gap between socialist ideals and reality: not only were they playing with the socialist tenet of women as gauges for social change to criticise the regime, but in choosing to portray female characters on the basis that prevailing patriarchal attitudes would dismiss women's voices, the filmmakers were pointing to the divergence of socialist ideals of gender and social equality to the gendered reality regulating women's lives and highlighting the lack of real social change.

The effect of Kühn's statement is two-fold: on the one hand, women and depictions of women played a central role in constructing a dialogue opposed to the socialist regime, but on the other hand Kühn's statement reveals an inherent gender stereotyping in DEFA productions that contributed to the discourse of "outdated attitudes" that prevented women from taking advantages of the changes to women's roles under Honecker. ${ }^{48}$ By constructing "a binary opposition of male and female qualities on screen," men came to represent "external authority, the public sphere, stability and stagnation, entrapment and denial" (Rinke, 1999: 201). Women meanwhile represented ideals, the private sphere and the everyday - a discourse emphasising traditional

\footnotetext{
${ }^{47}$ As pointed out by Rinke, DEFA filmmakers often addressed controversial topics " "through the back door,' avoiding censorship by conveying coded messages through allusions and images rather than the spoken word" (Rinke, 2006: 35). The use of female characters as metaphors can be seen as one of these 'back door' techniques.

${ }^{48}$ Women's literature and theatre from the seventies and eighties was also used to construct a counterdialogue to socialism, proposing female alternatives to the patriarchal norm of life in the GDR (Sieg, 1995: 108).
} 
gendered attitudes. It also adds weight to the argument that despite socialist morality easing as a source regulating women's behaviour, increasingly patriarchal attitudes sought to centre women's lives on the domestic sphere.

Although gendered concepts were at the heart of Frauenfilme from the seventies and eighties this did not lead to sexist portrayals of gender relationships. Indeed, feminist analysis of DEFA Frauenfilme has often pointed to such gender stereotyping as resulting in depictions of inferior female characters. ${ }^{49}$ However, in presenting women as more emotional and passionate than the rigidly authoritarian male characters, it is women who come across as more humane and morally superior and this is certainly the case in Die Legende, which constructs the heroine Paula as a modern day saint. As discussed by Rinke, women in DEFA productions are depicted as strong and resilient, as people who "fight for their ideals and dreams - against all odds - and they air their views passionately" (Ibid). If anything, women are portrayed as more ideological and utopian in their outlook, as expecting more out of life than their male counterparts. In depicting such women and creating a "binary opposition" where men represent authority and women utopian ideals, filmmakers were constructing a female alternative to the patriarchal socialism of the SED and in doing so were wedging a role for women and women's experiences in GDR society, much in the same way as Christa Wolf did in Nachdenken über Christa T.

The fact that these cinematic depictions coincide with the subjective, and arguably more authentic, woman's voice in Christa Wolf's Nachdenken über Christa T. points to the validity of the films as representations of women's desires. While the use of female characters as metaphors for greater societal discontent could be construed as

${ }^{49}$ See for example: Helke Sander and Renate Schlesier, 1974. 
reducing the validity of the films as sources on women in East Germany, the correlation between how Wolf portrayed women's need for self-actualisation and its portrayal in cinema implies that the films corresponded to women's lives and sentiments in the GDR. Furthermore, not only was the need for self-fulfillment and self-determination felt by women, but through using female characters as metaphors the filmmakers were making a more general statement about society and the need for the individual to break out of the collective and achieve self-actualisation.

Indeed Wolf used the creation of an intermediary character in order to circumvent censorship, much in the same way that filmmakers used female characters as metaphors. In an analysis of East German women's literature from the late sixties onwards, Alison Lewis points to the 'splitting' or 'duplication' of female characters as a mechanism to avoid censorship. With regard to Nachdenken über Christa T. the splitting of the female voice between the narrator and Christa $\mathrm{T}$ was done so that the non-conformism of Christa T's life could be mediated by the narrator's memory; this watered-down version more acceptable to the censor than as a straight biography of Christa's atypical life (Lewis, 1993: 376). Additionally, the identification of Christa Wolf as a living Christa T is moderated by the narrator's voice, with Lewis pointing to Wolf's reference to the "difficulty of saying 'I" as resulting "from a reluctance to use the autobiographical form" (Ibid: 377). The splitting of the female voice was also used by Wolf in her following novel Kindheitsmuster (Patterns of Childhood, 1976). The use of devices to avoid censorship in both cinema and literature highlights that although Honecker may have liberalised cultural policy in the early seventies, there were some topics that were still taboo. 
What can be said of the seventies is that it was a period of great social change in the GDR, largely due to the change in leadership from Ulbricht to Honecker. Of key importance was the increased focus on the individual, as opposed to the collective, and the increase in Frauenpolitik. While the move to a more individualised socialism allowed women to desire more freely, the patriarchal policies of the SED continued to encourage traditional gendered attitudes towards women. This has led one scholar to comment that in the seventies "the contradiction between the promise of equality and the praxis of women's socioeconomic disadvantagement sharpened" (Sieg, 1995: 107). This contradiction, alongside the focus on the individual prompted a search for alternatives. In the cinema, these alternatives to SED style socialism were constructed as female, where women represented utopian ideals and the domestic sphere, and men stood for control and the state. Filmmakers could present such critical views of socialism due to the liberalisation of cultural policy under Honecker and the instrumentalisation of female protagonists, whose voices would be dismissed, by virtue of traditional attitudes that saw women as prone to emotional excess. In gendering socialist alternatives as female, filmmakers were taking off from Wolf's subjectivisation of the authorial voice, and creating a role for women and women's experiences in the GDR.

\section{Der Dritte and Die Legende von Paul und Paula}

In the twenty years between the release of Frauenschicksale and Der Dritte much had changed in East Germany. There had been unprecedented economic growth, with national income rising by 25 percent between 1966 and 1970 . Following on Willy Brandt's Ostpolitik, East Germany's isolation was bridged, its international relations 
improved, and it even joined the United Nations in 1973. Contact with West Germany was formalized with the Basic Treaty, signed in 1972, in which both states recognised each other as sovereign. Furthermore, the seventies ushered in the era of détente of Cold War tensions. Importantly, many of these changes were precipitated by the 1971 accession of Erich Honecker to the position of First Secretary of the SED.

The Five-Year Plan enacted under Honecker in 1971 introduced many of the social developments that would influence the regulation of women's desires and how these desires and women would be depicted in cinema. The Plan's call to improve the well-being of the East German citizenry led to a massive housing project with many older apartment buildings torn down and replaced by Neubauten (massive new apartment buildings), and there was a development of consumer products and an increase in consumerism. However, materialism and consumerism were still regarded as feminine domains; a discourse that originated in the post-war period. Within this climate, women's material desires were no longer at odds with a society suffering from rationing. In terms of women's sexual desires, the relaxation of the sexual conservatism of the 1950s and early sixties meant that women had increasing sexual autonomy. Sexual relationships were no longer expected to lead to marriage and reproduction, and the decriminalisation of abortion and introduction of the oral contraceptive pill allowed women to desire more freely. Fundamental to these changes was a move towards realexisting socialism and away from the utopian discourses under Ulbricht and concepts of the socialist personality and socialist morality. Women were increasingly allowed to express themselves as individuals, and behaviours such as promiscuity and material excess were no longer constructed as against socialism. 
While socialist morality may have ceased to be an authoritative control over women's sexual and material desires, patriarchal notions that sought to confine women's primary roles to the domestic sphere gained momentum. These traditional gender constructions form the basis of the gendering of consumerism, and are evidenced by the high levels of female employment in 'female' sectors, such as the textile and service industries. For the regulation of women's desires, this meant that although women were able to desire more freely, they could not desire in a way that removed them from their primary duty of housewife/mother/carer.

Read in the context of the 1965 Kahlschlag and 1968 Prague Spring, these social and political changes drastically changed the manner in which women and women's desires were portrayed in Gegenwartsfilme during the seventies. Relations between artists, in particular filmmakers, and the state were fundamentally altered after the Kahlschlag, with filmmakers having experienced severe censorship for the first time. Furthermore, the Prague Spring highlighted the repressive direction of socialism in the eastern bloc, provoking many artists to question socialism and to mourn the loss of their socialist aspirations. These questions would lead to the aesthetic of Utopieverlust and the search for alternatives to SED socialism.

Many of these changes were prefigured by Christa Wolf's novel Nachdenken über Christa T. The failure of socialism to reach its utopian goals manifested itself in critical cinematic depictions of everyday life in East Germany, where socialist ideals of gender equality and self-actualisation were contrasted with the reality of socialist praxis in East Germany. Such critical depictions of life in East Germany, alongside a preoccupation with the tension between the ideal and reality were dominant themes in 
the cinema of the seventies and eighties that originated in the cinematic period prior to the Eleventh Plenum and also manifested in Nachdenken über Christa T. Indeed, many of the developments that occurred with this breakthrough text of Wolf's would inform the cinema of the coming years. Not only did Wolf begin the movement away from socialist realism with her appropriation of the narrative voice, but her text was premised upon a quest for self-actualisation. Further still, Wolf's preoccupation with private narratives based upon personal experiences reflects the cinematic trend to depict the everyday private sphere that began in the early seventies. Most importantly, Wolf created a space for women's experiences in GDR literature, which would come to be reflected by the construction of female alternatives to socialism in cinema of the early seventies.

These developments stand in stark contrast to the didactic socialist realism of Frauenschicksale. Whereas depictions of women in the fifties and sixties were confined to positive ideals regulated by the framework of socialist morality, designed to instruct female viewers on the correct behaviour under socialism, by the seventies, thanks to the relaxation of socialist morality, female protagonists were moving away from this ideal towards the boundary of East German society, and depictions of non-conformist female protagonists like Christa $\mathrm{T}$ in Nachdenken über Christa T. and, as will be argued in the following chapter, Margit in Der Dritte and Paula in Die Legende, began to become widespread.

Although the cultural liberalisation introduced under Honecker permitted these innovative depictions of daily life in East Germany, filmmakers still employed devices to code more critical messages, in order to avoid censorship. One such device was the 
instrumentalisation of female protagonists as symbols of greater societal discontent. In doing so, filmmakers relied on persisting gender norms that ensured that women's voices would not be taken as seriously as men's. Christa Wolf also employed a similar encoding technique, splitting the narrative, to avoid censorship.

The following chapter will examine how the changes to the regulation of women's desires and the developments in the cultural sphere discussed in this chapter manifested themselves in two films from the early seventies: Der Dritte, directed by Egon Günther and Die Legende von Paul und Paula, directed by Heiner Carow. The two films demonstrate the developments in East German cinema away from socialist realism toward more innovative aesthetics and themes. Further, both films present protagonists who use their desires as mechanisms through which to achieve selffulfillment. The manner in which the two protagonists search for self-fulfillment is presented as providing an alternative to SED socialism, because in searching for fulfillment, the protagonists find that their expectations of socialist society cannot be realised. Whereas Die Legende, like Nachdenken über Christa T., uses the theme of selffulfillment and actualisation to highlight the gap between socialist ideal and reality, Der Dritte uses the protagonist's autonomous sexual desires to question whether gender equality had actually been created in the GDR. Whether these female protagonists are read as metaphors for greater societal discontent or as genuine depictions of women's issues at the time, both imply the difficulty of saying 'I': namely, the difficultly for individuals, both male and female to achieve self-fulfillment. 


\section{Ideal and Reality Never Go Together}

A man has the right...to say: 'I like you. Maybe we could...' If I, a woman, say 'No' to him, he can just leave, his dignity intact. If I, a woman walk up to a man and say: 'Maybe we could...,' and he says 'No' to me, then I have suffered a defeat for myself, for my friends and acquaintances...I have overstepped the mark. (Rücker qtd in Rinke, 2006: 63)

In years to come, people should tell each other the story: There was a man who loved a woman so much that he broke down her door, because he had to be with her. Or: There was a woman who would rather die than not have a child by him. These are elements which may be passed on through generations (Carow qtd in Herlinghaus, 1983: 44) ${ }^{51}$

Der Dritte, released in 1972 and Die Legende von Paul und Paula ('Die Legende'), released in 1973 are two of the most well known Gegenwarts- and Frauenfilme produced by DEFA. Their popularity, particularly in the case of Die Legende, spanned both East and West German audiences. Released soon after Honecker's "no taboos" pronouncement of 1971, Der Dritte, directed by Egon Günther, and Die Legende, by Heiner Carow, were among the earliest films to take advantage of the new cultural freedoms of Honecker's rule. Importantly, both films feature female protagonists searching for self-fulfillment through the realisation of their desires. It is the failure of socialist society to accommodate these desires that cause the protagonists to criticise the disparity between reality and expectations under socialism.

The failure of socialist reality to meet individual needs and wants forms the heart of Der Dritte. The film focuses on the life of Margit, a model socialist woman, who,

\footnotetext{
50 "Ein Mann hat das Recht,...zu sagen: “Du gefällst mir, wir könnten doch...” Wenn ich dann 'nein' sage als Frau, dann geht er und hat nichts weiter verloren. Wenn ich als Frau zu einem Mann gehe und sage: "Wir könnten doch..." und er sagt 'nein,' dann habe ich selbst für meine Freundinnen, Freunde und Bekannten eine Niederlage erlitten...Ich habe etwas getan, was mir nicht zusteht."

51 "Später müßten sich die Leute erzählen: Da war einer, der hatte eine so geliebt, daß er ihr die Tür eingeschlagen hat, weil er zu ihr mußte. Oder da war eine, die wollte lieber sterben, als das Kind nicht von ihm bekommen. Das sind Elemente wie sie durch die Generationen möglich sind."
} 
having achieved professional success is preoccupied with looking for personal fulfillment. In pursuing the man she wishes to be her third life partner, she takes the official emancipation of women at its word, attempting to cast off the traditional role of the submissive female lover. Using Brechtian alienation techniques, Günther portrays Margit's confrontation with gender roles that confine women to the role of object in romantic pursuit. In doing so, he challenges the purported success of women's emancipation in the GDR, while questioning the socialist precept that women's emancipation comes solely through economic independence. Material desires and consumption, in contrast to sexual desires, are portrayed as an alternative path to personal fulfillment. The failure of socialism to meet these material desires highlights the film's message that the true path to happiness comes through emotional, rather than material, fulfillment.

Die Legende, on the other hand, critically portrays the failure of the socialist system to tolerate true and passionate love, the kind of love with the potential to undo the ties that bind people to socialism. Unlike the Brechtian didacticism of Günther, Carow uses magic realism and the leitmotif of a legend to underscore Paula's joie de vivre, emphasising the transformative and liberating effects of her love and desire. Sexual desire in Die Legende is portrayed critically as a subject that is both observed and regulated by the state. The "subversive potential" of Paula's sexual desires is not only depicted through her ability to take Paul away from his socialist responsibilities, but also through her reversal of traditional sex roles (Rinke, 2006: 151). Material desires, on the other hand, are portrayed as more acceptable within socialism and indeed are used to encourage conformity by the Party. It is not insignificant that both Paula and Paul's wife 
Ines turn to marriages of convenience to ensure their material well-being. Similarly to Günther, Carow questions the notion that socialism, simply by giving women economic independence from men, provides the ideal environment for true love.

The aim of this chapter is to demonstrate the ways in which the changes in the depiction of women's subjectivity discussed in the previous chapter were manifested in the representations of desire in Der Dritte and Die Legende. These films not only reflect the instrumentalisation of female characters by filmmakers as metaphors and feature unique non-socialist realist aesthetics, but both Margit and Paula are constructed as 'outsiders,' standing in contrast to the ideal female portraits of Frauenschicksale. Furthermore, in focussing on the search for fulfillment, the two films demonstrate the difficulty the protagonists' face in "saying 'I,'” in stepping away from expected gender and societal norms and realising their own desires. The difficulty the protagonists face in realising self-fulfillment is used to both critique and subvert the socialist regime as unable to reconcile ideals with reality. Importantly, both films present a female socialist ideal constructed as an alternative to SED style socialism.

In terms of desire the two films highlight how women's wants and needs were still regulated by an underlying patriarchy at a time when socialist morality itself was loosening. Interestingly, the Party's critical response to the open depiction of female sexuality in the films demonstrates that despite relaxing socialist morality, the SED still held sexually conservative values. The manner in which the two films portray the regulation of women's sexual and material desires comprises the main focus of this chapter. It is argued that both films depict a persisting regulation of women's sexual desires, which is then contrasted with material desires. Whereas in the fifties women's 
desires were portrayed as problematic when they inspired the female character to leave the collective, in order to instruct the East German women on the expected mode of behaviour under socialism, in Der Dritte and Die Legende the fulfillment of desire is portrayed as equally problematic, but done so in a critical fashion to highlight the inability of the SED to tolerate individual wants and needs. Furthermore, while the fulfillment of sexual desires is particularly problematic, the acquisition of material possessions is depicted not only as acceptable, but also as a mechanism ensuring allegiance to the Party.

\section{Der Dritte (Her Third)}

Director Egon Günther, born in 1927 in Schneeberg, Saxony, began his creative career as a writer, with his first publication Die Zukunft sitzt am Tische (The Future Sits on the Table), a collection of poems written together with Reiner Kunze, released in 1955 (Pflaum, 1977). In 1958, he began working for DEFA as a dramaturge and screenwriter. In spite of these literary beginnings, Günther is best known for his direction and is characterised as a DEFA 'wild child,' often facing censorship problems for his playful, tongue-in-cheek depictions, with his film Wenn du gross bist, lieber Adam (When You Grow Up, Dear Adam, 1965) even banned during the Kahlschlag. Günther's fourth movie made with DEFA, Der Dritte, was also met with controversy and criticism for its open portrayal of women's sexuality, including lesbianism, and what some saw as a mocking tone towards the Party. ${ }^{52}$ Not unsurprisingly, given this negative attention,

${ }^{52}$ Der Dritte was preceded by Lots Weib (Lot's Wife, 1965), Wenn du gross bist, lieber Adam (When You Grow Up, Dear Adam, 1965/1990) and Abschied (Farewell, 1968). 
Günther immigrated to West Germany in 1978, after his film Ursula ran into severe criticism from the SED, not returning to East Germany until 1989 (Egon Guenther).

Described at the time as "one of the most interesting films" to have come out of DEFA, Der Dritte, based on the novel Unter den Bäumen regnet es zweimal (Under the Trees it Rains Twice, 1969) by Eberhard Panitz and adapted by Günther Rücker, was widely popular in the GDR, often drawing applause during screenings (Eder, 1972; From the Series, 2000). ${ }^{53}$ The film recounts the story of Margit Fliesser (Jutta Hoffmann), a thirty-something single mother. Through a series of flashbacks, the film narrates Margit's life: from the death of her mother in the immediate post-war period, to the heightening of Cold War tensions in the sixties, and, finally, to Margit's 'present' Honecker's East Germany of the seventies. Having two failed relationships Margit, unwilling to grow old alone, determines that her third man, Hrdlitschka (Rolf Ludwig) will be different from the first two; she will learn as much as possible about him before entering into a relationship. In doing so, she attempts to enact official emancipation in her private life, by casting off the traditional role of the passive female lover pursued by the aggressive male. However, she is unable to approach Hrdlitschka directly and say "I like you" and instead reverts to the role women are traditionally expected to play in romantic relationships, but not without first criticising the failure of socialist society to emancipate women from traditional gender roles. The film ends with Margit's marriage to Hrdlitschka, although the question whether she has found true happiness and fulfillment remains unanswered.

Der Dritte was one of the first DEFA films to illustrate the trends that would develop in Frauenfilme throughout the seventies and eighties, and as such has been

53 “...einer der interessantesten Filme, die ich in den letzten Jahren aus der DDR gesehen habe" 
labelled as marking a new phase in DEFA history (Blunk, 1984: 219; Gersch, 2006: 138; Kersten, 1997: 9). Firstly, Günther's use of female characters corresponds to the trend of using female protagonists as metaphors: socialist women were more closely connected with concepts of social change and self-realisation (Rinke, 2006: 61). Also, Günther's use of a storyline critical of socialism and gender relations heavily focused on the everyday signposted the shift away from socialist realist aesthetics that would further develop in the years to come. Instead of having plots set in the workplace, films after Der Dritte experimented with more innovative aesthetics, and featured storylines based on the everyday experience of socialism, many examining issues of gender and themes of ideal and reality. Finally, through Margit's attempts at fulfillment, Günther is presenting the audience with a more idealised image of socialism.

To a certain extent, however, Der Dritte built upon aesthetics and themes already present in East German cinema and literature. Firstly, Margit, corresponds to those positive heroines of the Gegenwartsfilme of the 1960s, depicted in a similar fashion to Barbara in Frauenschicksale, encapsulating many of the ideal traits of a socialist woman: she is employed, well educated and politically active. Furthermore, the thematic concern with ideal and reality was the central theme of Nachdenken über Christa T., as was the quest for self-fulfillment and actualisation - all surfacing on celluloid in Der Dritte. Despite such similarities, Der Dritte did mark the beginning of the new phase of liberal cultural policy under Honecker, moving away from depicting dogmatic world views, towards the use of more Pop-Art, sub-culture elements (Blunk, 1984: 219). This experimental era would end after the controversy surrounding Die Legende. 
Importantly for this study, Der Dritte uses desires, particularly Margit's sexual desires, as a vehicle to examine her need for self-fulfillment and the contradiction between socialist ideals and their enactment in the daily life of East Germans. Although the film focuses on the romantic and sexual needs of the protagonist Margit, the central thrust of Der Dritte is the double standard that regulates women's roles in the public sphere, where women are supposedly emancipated, while in their private lives they remain governed by patriarchal concepts dictating how women should behave. Affirming this, the screenwriter for Der Dritte, Günther Rücker, stated that his "principal theme was the woman who, having developed her intellect, decides to take the law at its word....And suddenly she discovers inconsistencies" (qtd in Rinke, 2006: 60). ${ }^{54}$ The main mechanism for presenting this message in Der Dritte is the use of Brechtian alienation techniques, such as inter-titles and abrupt changes in music that aim at preventing an emotional connection between the viewer and the characters, thus emphasising the film's critical message.

The double standard faced by women is further emphasised through the character of Margit, a consummate example of the socialist heroine, reflecting both socialist ideals, as well as the personality traits typically associated with socialist women and a personal history grounded in the founding and establishment of East German socialism. Like many women in the GDR, Margit is a single mother, hard working, self-assured and resilient, managing to bounce back each time she is left by a man and continuing her education, in spite of having two young children. In highlighting Margit's typical socialist characteristics, director Günther stated:

54 "Als Hauptthema fand ich die Frau, die intellektuell gewachsen ist und das Gesetz mal beim Wort nimmt...Und plötzlich entdeckt sie Widersprüche" 
Margit is the archetype of what is called the conscious GDR female citizen...She is single, divorced, with two children, even by two different fathers. She knows that such a woman would be discredited by any bourgeois society...The inner security emanating from her can only be derived from the convictions of society at large. (qtd in Rinke, 2006: 64) ${ }^{55}$

In terms of socialist characteristics and values, Margit is politically involved, and is seen taking union dues from her co-workers. She is also well educated, holding a good job as a mathematician, working as a computer programmer at a chemical factory. Indeed, her involvement in a typically 'male' field serves to highlight her as an emancipated figure. Additionally, working with computers emphasises her contribution to the scientifictechnical revolution, reinforcing her socialist credentials. Importantly, Margit's idealised character is matched by actress Jutta Hoffmann's physical similarity to the East German feminine ideal: her slim physique emphasises a seemingly fit and healthy lifestyle, yet she is clearly feminine without appearing overly sexualised. In selecting Jutta Hoffmann to portray the character of Margit, Günther commented that she "corresponded to an almost unbelievable extent with all the typical characteristics expected from GDR women" (Ibid).

Furthermore, Margit's childhood and education corresponds to post-war experiences and the establishment of the GDR. Margit's socialist education is depicted throughout the film in a series of flashbacks, signified in typical Brechtian fashion with inter-titles, such as 'Tod der Mutter' (Death of the Mother) and 'Jugend' (Youth). These titles not only break the narrative flow, but the impersonal nature of the titles prevents an emotional connection between protagonist and viewer. Margit's story begins in

\footnotetext{
55 "Margit ist absolut das, was man eine bewußte DDR-Bügerin nennt...Sie is alleinstehend, geschieden, hat zwei Kinder, noch dazu von zwei verschiedenen Männern. Sie wei $\beta$, da $\beta$ eine solche Frau in der bürgerlichen Gesellschaft diskreditiert würde...Diese innere Sicherheit, die sich bei ihr ausdrückt, ist nur ableitbar vom allgemeinen gesellschaftlichen Bewußtsein"
} 
childhood with the death of her mother, coinciding with the fall of the Third Reich, reflecting the political and social turmoil of 1945 . Although the reference to the fall of the Reich is not made explicit, it is depicted symbolically through the plundering of the dead mother's bedroom, which Margit watches helplessly. The tapestry hanging on the wall behind Margit, depicting swooping birds of prey has been read as a symbol of the dismantling of Germany by the Occupying Powers, sinisterly conjuring images of the raping Soviets (Blunk, 1984; Blunk, 1997). After this, Margit moves to the Diakonissenheim (a convent school), but rejects this life after spending time in the workforce, choosing the collective and socialist values over the bourgeois practice of religion. As remarked by Harry Blunk, Margit's entrance in the Diakonissenheim reflected the need to return to the values of humanity after the moral catastrophe of the Holocaust (Blunk, 1984: 208). As an adult, Margit's work as a computer programmer emphasises the development and scientific progress made during the late sixties and early seventies in the GDR. Similarly, Margit lives in a Neubau building, illustrating the massive building project undertaken by Honecker in the 1971 Five-Year Plan. As suggested by Erika Richter, Margit's biography is "moulded by characteristic social processes which took place in our country post 1945 " (qtd in Rinke, 2006: 68). ${ }^{56}$

Margit's ideal traits and proto-typical East German development serve to strengthen the critique of the socialist state. Unlike the heroines of Frauenschicksale, Margit is unable to overcome her emotions through adherence to socialism. The juxtaposition of the advancements made by socialism in technology and the emancipation of women to the out-dated gender norms Margit faces underscores the central issue of unfulfilled expectations and double standards. In this respect, Margit's

56 "Charackteristische soziale Prozesse, die sich nach 1945 bei uns vollzogen, prägen diese Biographie" 
search for fulfillment can be compared with Christa T's quest and the theme of ideal and reality in Wolf's Nachdenken über Christa T. Both women are confirmed socialists, yet socialism fails to meet their expectations.

Throughout the film, Margit's socialist development is juxtaposed with her personal and sexual awakening. After leaving the Diakonissenheim for a vocational education, Margit becomes a passionate socialist, reflecting as an adult that "I always ran around in my blue [FDJ] shirt... I was so, so stiff and proper. I took it really seriously combat week, and the future" (Günther, 1972). ${ }^{57}$ In the segment titled 'Der Erste' (Her First) Margit visits Bachmann, her vocational school Physics teacher on the pretence of asking a question. Wearing her blue FDJ shirt, Margit sits nervously on the couch. Avoiding his eye contact, Bachmann serves Margit her first schnapps. He then proceeds to kiss her, but she pulls away when he begins feeling up her leg. In an attempt to relax Margit, he turns on the radio, accidentally tuning into the communist song Bandiera Rossa. At hearing this Margit, jumps up crying "I know that song" and begins twirling and clapping to the music, singing the refrain 'Avanti popolo' (Ibid). ${ }^{58}$ As pointed out by Rinke, Margit dances "herself into abandon to a song used in political agitation which, comically, leads her to her first sexual experience" (Rinke, 2006: 69). ${ }^{59}$

While Margit is sceptical about the strong socialist convictions of her youth, shown in the comical Bandiera Rossa sequence, she remains a committed socialist as an

\footnotetext{
57 “Ich bin immer rumgerannt, im Blauhemd...Ich war so, so tüchtig und stramm. Ich hab' das richtig ernst genommen...Kampfwoche und Zukunft"

58 "Das kenn' ich"

${ }^{59}$ This was one of the more controversial scenes in Der Dritte. In an interview with Jutta Hoffmann, she recollected that soon after the film was released she sat next to Kurt Hager, the Chief Ideologue for the SED, who told her that mocking worker's songs was not allowed, to which she responded that the song would be forgotten if it was not used (Hoffmann qtd in Poss, 2006: 280).
} 
adult. When her friend Lucie offers to investigate western dating agencies for Margit, she refuses, telling Lucie:

Hamburg or New York values don't apply to us. What is success for them is for us dishonesty. What is terrible for them, is interesting to us. What we call criminal, they call politics. (Günther, 1972) ${ }^{60}$

This demonstrates that as well as embodying socialist ideals through involvement in the workforce and political participation, Margit has also internalised socialism, and applies the values and ideals of socialism to her personal life.

At this point, Margit's similarity to the socialist realist heroines of the fifties and sixties ends. Although Margit, like these heroines attempts to develop all aspects of her personality - through gaining an education and political activity - unlike the films of that era, the failure of socialist society to meet her aims is used to critically address the problems of socialism. As an emancipated socialist woman, Margit believes that she should be able to apply socialist values to her personal life and approach her desired man, but in attempting to do so, she discovers that while emancipated in the workforce, in the private sphere she is still expected to uphold traditional female gender roles. In contrast to the asexual socialist realist heroines of the fifties, Der Dritte also demonstrates that women have an "erotic dimension, in which problems can arise, that can be more difficult to solve than problems in the workforce" (Pflaum, 1977: 128). ${ }^{61}$ When Margit first meets Hrdlitschka, she is determined not to repeat her past mistakes and to eschew traditional gender roles. ${ }^{62}$ The opening segment of the film

\footnotetext{
${ }^{60}$ Die Hamburger oder New Yorker Werte stimmen nicht. Was für die Erfolg ist, ist für uns Unlauterkeit. Was für die schrecklich ist, ist für uns interessant. Was für uns kriminell ist, ist für die politisch. 61 "....zeigt der Film, dass Menschen auch eine erotische Dimension haben, in der Probleme entstehen können, die mitunter schwerer zu lösen als Konflickte in der Arbeitswelt"

${ }^{62}$ Margit's determination to learn from her mistakes is also emphasised in the flashbacks relating Margit's past relationships, where the inter-titles read 'Der Erste' (Her First) and 'Der Zweite' (Her Second), rather
} 
shows Margit alone in her kitchen, preparing dinner. In an attempt to fill the apartment with life, Margit turns on the television, which is showing the Soviet film Ivan's Childhood (1962) set on the Eastern Front of World War II. The clip of the film shows a Russian soldier escorting a young woman and haranguing her with his advances. When the pair comes to a ditch, the soldier insists that he help the girl with the crossing. Ignoring her refusal, the soldier grabs her and, as he holds her captive over the ditch, forces a kiss on her. The clip emphasises the traditional image of the woman as a coy mistress, feigning disinterest in the man's affections. It is this objectified role that Margit is trying to avoid, and it is a role linked to her first love interest. A visual comparison is made between the scene from Ivan's Childhood and a later sequence of Margit with 'Her First' playing in the snow. During this scene, Margit is seen 'resisting' the advances of Bachmann as he grabs her around the waist teasing her for withholding. Interestingly, Bachmann, similarly to Conny in Frauenschicksale, is portrayed as a bourgeois character, reminiscent of the pre-war days: his apartment is luxurious and he is frequently heard undermining and criticising Margit's socialist involvement (Rinke, 2006: 70). At one point, Margit even asks him if he preferred the pre-war days, to which he grunts musingly in response. Bachmann is also a womaniser and somewhat predatory; he is clearly older than Margit and preys upon her inexperience. In spite of this Margit is never portrayed as a victim or unwilling, but rather responds with gusto. Eventually, the relationship ends when Margit falls pregnant, with Bachmann, like Conny, abandoning his conquest, leaving her to care for the child alone. The link between Bachmann's reactionary and bourgeois character and his objectifying treatment

than identifying these men by name. In doing so, Günther is highlighting that the men themselves are not of importance, but rather it is the experience that Margit has gained from being in these relationships, experience that she puts to use in determining whether Hrdlitschka will be her third man. 
of Margit highlights Günther's didactic message that such traditional gender roles in romantic relationships are outdated and incongruent with socialist values of gender equality.

Margit's desire to know everything about Hrdlitschka before entering into a relationship with him is not only linked to her wish to avoid past mistakes, but also to her overpowering sexual desires. When Hrdlitschka is first introduced, Margit makes it clear that she intends for him to be her husband, but that she cannot be near him until she knows everything. Margit explains this to her friend Lucie, saying

I was alone for so long, I would want him and how! And I would stay by him and overlook everything. Until one day, I would see, and then for the third time it's too late. I've been fooled two times. I need to know: does he keep his fingernails clean? Does he look at other women? How he is with money? Everything. (Günther, 1972) ${ }^{63}$

In doing so Margit is regulating her own sexual needs: she refuses to enter into a sexual relationship that could lead to her to another womaniser, or, as with her 'Second One,' an alcoholic who could not look after himself and fled to the West after stealing union money. Margit's self-regulatory and individualised approach to her own romantic fate reflects her need for self-actualisation, and the turn towards the individual in the early years of Honecker's rule. Indeed, Margit's control over her sexual and romantic desires is a prerequisite for her self-actualisation: as she makes clear, if she lets her desires overpower her, she would lose her agency in determining whether Hrdlitschka would be her Third.

\footnotetext{
63 "Ich war so lange allein, ich würde ihn haben wollen, und wie! Und ich würde bei ihm bleiben wollen und über alles hinwegsehen. Bis ich dann eines Tages sehen würde, und dann ist es zum dritten Mal und zu spät. Zweimal bin ich reingefallen mit Pauken und Trompeten. Erst wissen...ob er die Fingernägel sauber hält, den Frauen nachsieht, wie er zu Geld steht. Alles. Alles wissen."
} 
Despite wanting to enact her professional emancipation, Margit cannot avoid the typical courting rituals played between men and women, resorting to spying on Hrdlitschka. The comical way that Margit's espionage is portrayed underscores a critical attitude towards these passé courting games. In one scene, Margit follows Hrdlitschka onto the train and sits across from him in an attempt to gain his attention. Hrdlitschka, meanwhile, sits reading, oblivious to Margit's intentions. The awkward conversation that ensues pokes fun at Margit's endeavours:

Hrdlitschka: Don't you work at the chemical factory?

Margit: $\quad$ Yes. I'm visiting a sick friend. She's sick. Yes.

Hrdlitschka: Why don't you get off at my stop? We can walk, get some fresh air. Over the mountains to...well, to the river. Then you can hitch a ride and half an hour later you're at friends place.

Margit stifles a giggle and covers her mouth

Margit: $\quad$ My friend's meeting me at the train station. Or...maybe she's too sick to come to the station.

Hrdlitschka: Ah ha....Goodbye

Margit: $\quad$ Bye (Ibid) ${ }^{64}$

Margit's stilted dialogue and repetition of the word "sick" highlights her vain attempt to fabricate an excuse for being on the train. The comedy of this scene is emphasised through the cinematography. The scene is shot from the door of the train cabin with Margit and Hrdlitschka sitting next to the window, with the camera panning between the two characters profiles, allowing the viewer to see Margit's reactions as she concocts the

\footnotetext{
${ }^{64}$ Hrdlitschka: Sind Sie nicht aus dem Werk II?

Margit: Ja. Ich besuch eine kranke Freundin. Sie ist krank. Ja.

Hrdlitschka: Versteigen Sie doch mit mir aus. Laufen ein bisschen, bisschen frische Luft. Über die Berge, zum...naja, zum Fluß. Halt man Auto an und "ne halbe Stunde später sind Sie bei Ihre Freundin.

Margit: $\quad$ Meine Freundin erwartet mir am Bahnhof. Oder, sie ist so krank das sie nicht zum Bahnhof kommen kann.

Hrdlitschka: Tja...Auf Wiedersehen

Margit: Wiedersehen
} 
story about her sick friend. After Hrdlitschka leaves the cabin, Margit falls back into her seat and stares out the window, embarrassed at herself for fabricating such a story.

It is not only the comical portrayal of courting rituals that reveals Günther's negative attitude towards such outdated behaviour; Margit is critical of her own actions. Although she succumbs to playing games, she does truly try to behave differently, frequently heard criticising the underhanded role women are expected to play in courtship. Nowhere is this more clearly demonstrated than in the scene titled Der Dritte (Her Third), where Margit is seen spying on Hrdlitschka at the train station, having once again bought a ticket for the same train. The scene begins with Margit framed by two columns, through which she watches Hrdlitschka. As she begins her interior monologue, the shot cuts to Hrdlitschka from Margit's point of view, making him the gazed object, as if he were the prey and she the hunter. Again Günther emphasises the humour in the situation, with Margit jumping behind one of the columns to hide as Hrdlitschka turns to her direction. During the scene Margit's interior monologue is heard as a voice-over, where she bitterly remarks at the falsity of courtship rituals:

The time has come. You are now going to board the train, and so will I. You will speak to me. In two days you will ring me. In one week you will ring my door bell. In a few weeks the children will have got used to you, and in a few months you will have got used to them...Sometimes I'll keep a tight leash on you, sometimes I'll loosen it, and if only I'm hard enough and gentle enough, then you will have said 'I Do' before autumn is over (Ibid) ${ }^{65}$

As the train comes, Hrdlitschka boards, but Margit cannot bring herself to follow him, saying in her monologue: "How undignified! The silly old games of grandma's day. I

\footnotetext{
65 "Es ist soweit. Du wirst jetzt einsteigen und ich werde einsteigen. Du wirst mich ansprechen. Nach zwei Tagen wirst du mich anrufen. Nach einer Woche an meiner Tür klingeln. In ein paar Wochen habe ich die Kinder an dich gewöhnt, nach ein paar Monaten dich an die Kinder...Ich lasse die Leine mal lang, mal halblang, und wenn ich nur hart genug bin und sanft genug, dann sagst du spätestens im Herbst dein Ja"
} 
may as well drop my handkerchief or faint, in order to get myself noticed. No, I can't do this. I can't. I can't" (Ibid). ${ }^{66}$ Margit does not want to play the contrived games that she, as a woman, is expected to play. The outdated nature of such rituals is highlighted in the reference to "grandma's day." In the following scene, Margit is alone in her bedroom; the intimacy of the scene demonstrated through a mid-shot of Margit's upper half. As if she were practicing a speech, Margit is talking to herself, repeating:

What should I do? I'll go to him and say, "I want you. Everything about you suits me. That's the truth." What should I do? I'll go to him and say, "I want you. Everything about you suits me. That's..." I'll go to him and say "I want you. Everything about you suits me. That's the truth (Ibid) ${ }^{67}$

Margit is preparing herself to visit Hrdlitschka, stumbling over various words as she shores up her confidence. The shot then cuts to Margit in an apartment building, with a cacophony of music, acting as a Brechtian alienation device and adding to the climactic atmosphere. Typically, Margit is thwarted in her attempt: as she reaches Hrdlitschka's apartment, there is another woman waiting at the door. Despite Margit's worst fears, it turns out that she is there in response to Hrdlitschka's advertisement for an apartment swap. The relief from the tension created by the music adds a touch of humour to the sequence. These comical elements have a similar Brechtian effect as the music, in that it breaks the emotional connection between the viewer and Margit, so that rather than empathising with Margit's plight to find a third man it is the foolishness of passé courting rituals that is highlighted.

\footnotetext{
66 “Wie würdelos! Das alte dumme Spiel der Grossmutter. Da kann ich auch gleich das Taschetüchel fallen lassen oder Ohnmacht sinken, um mich bemerkbar zu machen. Ach nein. Ich kann nicht. Ich kann nicht. Ich kann nicht"

67 "Was soll ich tun? Ich gehe zu ihm und sage 'Ich will dich haben. Alles an dir passt mir. Das ist die Wahrheit.' Was soll ich tun? Ich gehe zu ihm und sage 'Ich will dich haben. Alles an dir passt mir. Das...' Was soll ich tun? Ich gehe zu ihm und sage 'Ich will dich haben. Alles an dir passt mir. Das ist die Wahrheit."”
} 
Try as she might, Margit cannot escape the traditional role that women are expected to play when pursuing a man. Her exasperation leads her to complain to Lucie that as women they are "Emancipated, but without husbands" (Ibid). ${ }^{68}$ As if this comment were not enough to relate Günther's view that despite being emancipated in the workforce, women were still oppressed by traditional gender roles, when Margit finally approaches Hrdlitschka on the train and brings him to her house she exasperatedly comments on the double standards that women are expected to maintain. In Hrdlitschka's presence Margit addresses her daughters, saying:

For two years I've worked in engineering. I use a computer and a calculator, sometimes we call him Emil. I'm a mathematician. I work, think and feel in accord with the principles and politics of the socialist technical revolution. But, if I like a man, if I need him in my life, if I want him, in all probability I'll make a fool of myself if I tell him so. No, to attain my goal I have to hide my love and hide my desires deep down, because it might repel him. Right? Only him. He's the only one allowed to be proactive. Just like in grandma's day, I have to wait like a good girl and hope for a merciful fate...I have to hope for a merciful fate, that I get noticed, that he finds me desirable. I can only distinguish myself in his eyes through if I'm quiet and reserved in matters of love. If he touches me, it is still advisable to act coyly, avert my eyes and say no. Otherwise he is disgusted. He's experienced that sort of thing. Mum and Dad taught him what to think of girls like that. Do you understand that I don't want that? That I can't do that. That I felt fake, when I got on the same train pretending I was visiting a sick friend, only so you didn't notice that I was following you.I want you to notice me. To recognise me. Like I said, I didn't actually want to do it like that. But I did. I did it. I did it. (Ibid) ${ }^{69}$

\footnotetext{
68 "Emanzipiert, aber kein Mann"

69 "Ich arbeite schon zwei Jahre prognostisch. Mein Arbeitsgerät ist der Computer, der Rechner, manchmal nennen wir ihn Emil. Ich bin Mathematikerin. Ich arbeite, denke und fühle in Übereinstimmung mit dem technisch-wissenschaftlich-politischen Niveau unter sozialistischen Bedingungen der wissenschaftlichtechnischen Revolution. Aber wenn mir ein Mann gefällt, wenn ich den brauche zum Leben, wenn ich ihn haben will, mache ich mich aller Wahrscheinlichkeit nach immer noch lächerlich, wenn ich ihm das sage. Nein, will ich ans Ziel, muss ich meine Liebe verheimlichen, mein Verlangen ganz tief verstecken... Nicht? Nur er, er darf sich das erlauben. Ganz wie zu Grossmutters Zeiten muss ich brav dasitzen und auf ein gnädiges Schicksal harren... auf ein gnädiges Schicksal harren, das ich bemerkt werde, das er mich begehrenswert findet. Auszeichen kann ich mich in seinen Augen nur durch stille Zurückhaltung, stricktes abwarten in Sacheliebe. Fast er mich an, ist es immer noch geboten sich zu zieren, die Augen niederzuschalgen und erst immer Nein zusagen. Das will er nicht, störst ihm ab. Hat das so seine
} 
If it had not been made clear throughout the film, Günther uses this monologue to make explicit his didactic mission. Women, like Margit, can be emancipated and equal to men in public life and the workforce, but remain tied to gender roles within the private sphere that, according to Günther, belong to a different, older, generation. The persistence of these roles is incongruous with the ideals of socialism.

This scene also makes an important statement on the regulation of women's desires, namely, that although women were freer to regulate their own sexuality, they were still confined to publicly act in accordance with traditional gender norms. Throughout the film, both Margit and her friend Lucie are seen regulating their own sexual lives, with one of the earliest scenes showing Margit waking up with an anonymous man, and asking him to leave his key by the door. Further, both women are very aware and vocal about their sexual needs, with Margit even saying "Can a person live alone, Lucie? I can't, you know. Without a man...Lucie, I can't even let him near me. I have been alone for so long - I would want him, and how!" (Ibid). ${ }^{70}$ In contrast to this sexual freedom, Margit's monologue, quoted above, indicates that only men are allowed to be "proactive" and would be disgusted if a woman were to show any outward desire. This suggests that a different dynamic in the regulation of sexual desires existed in the public and private spheres. The scenes in which the two women's sexual power is most apparent occur in private moments in the bedroom or apartment, or shared between the two friends. In contrast, any public display of female sexual desire, such as Margit

Erfahrung, es ist also erzogen, der Vater und die Mutter auch. Verstehst du, dass ich das nicht will, dass ich das nicht kann, dass ich mich belogen fühle, wenn ich rein zufällig in den gleichen Zug einsteige, , ne kranke Freundin erfinde, nur damit du nicht merkst, ich fahre dir nach. Ich will, dass du mich siehst, dass du mich erkennst. Wie gesagt, ich wollte das nicht machen. Aber, ich hab 's gemacht. Ich hab's gemacht." 70 "Kann der Mensch allein leben, Lucie? Ich kann's nicht, du. Ohne Mann...Lucie, ich darf den gar nicht in meine Nähe kommen lassen. Ich war so lange allein, ich würde ihn haben wollen, und wie!" 
telling Hrdlitschka that she wanted him, would conflict too much with traditional female roles.

To a certain extent this dynamic aligns with Herzog's analysis of sexual relations in the GDR. Although the sexual space increasingly became an area where women could negotiate power, as demonstrated by the sexual assertiveness of Margit and Lucie, women were still publicly expected to uphold such traditional values as marriage (Herzog, 2005: 188). The importance of marriage was upheld throughout the history of the GDR up to the eighties. In an analysis of the column Unter vier Augen (Strictly Personal) in the years 1983 and 1984, published in the Party youth magazine Junge Welt (Young World), social scientist Rüdiger Pieper determined that marriage was an incontestable norm according to Party values (1986). This article also touches upon persisting gender norms as framing a 1980 survey asking young East Germans about various aspects of married life, including whether or not girls would want to stop work after having children (Ibid). Male participants were not asked this question. Both the article and survey illustrate the institutionalised patriarchy that existed in East Germany and sought to maintain traditional women's roles in the domestic sphere, which Der Dritte portrays as conflicting with the purported gender equality existing in the GDR.

The existence of these traditional attitudes, and their regulating effect on women's sexual desires were also evident in the Party's criticism of the film. In response to Margit's open discussions of her sexual needs, one critic commented that the film was "aiming a bit too low," claiming that "the realisation of equal rights in every aspect of our society requires the solution of problems far more complex and painful than the struggle with false inhibitions when selecting a life partner" (Kügelen qtd in 
Rinke, 2006: 67). These comments reflect not only on the persistence of gender norms as a regulatory framework for women's sexual lives, but also conflict with the loosening of socialist morality. As a further example, SED member Inge Lange called for the film to be banned for its portrayal of a lesbian kiss (Rücker qtd in Poss, 2006: 280). The film hints that Margit has lesbian urges, being taken on a seaside vacation from the Diakonissenheim following a scene depicting Margit with another young girl, where Margit encourages the girl to take her hood off, all the while stroking the girl's hair. The theme of lesbianism is then revisited as Margit is an adult, where, in Lucie's apartment, Margit begins to rub Lucie's arms and hair, to which Lucie responds sensually, eventually turning her face to Margit, where the two briefly kiss; the intimacy of the moment is emphasised by the shot which focuses on Lucie's body and Margit's hands. Lange's offence at the portrayal of lesbianism clearly reflects a conservative, if not homophobic, attitude towards women's sexual desires.

In terms of material desires, Der Dritte follows previously established depictions of consumerism, where materialism is gendered as a female concern. In this regard, it is Margit's friend Lucie who is often heard discussing new clothes and the problems of access to consumer goods, at one point comically remarking "With two things socialism is not finished. Fresh rolls and large busts" (Günther, 1972). ${ }^{71}$ Lucie is also expected to be thrifty and is chided by her boyfriend for not being more financially responsible. After buying an expensive armchair that cost 998 Mark, her boyfriend remarks

Lucie's Boyfriend: But to buy such a thing is lunacy. For that money, we could have at last gotten a couch and three armchairs as well Lucie: $\quad$ Happiness is expensive (Ibid) ${ }^{72}$

\footnotetext{
71 "mit zwei Dingen wird der Sozialismus nicht fertig: frische Schrippen und zu große Oberweiten" ${ }^{72}$ Lucies Freund: Aber sowas zu kaufen ist Irrsinn. Für dieses Geld hätten wir längst 'ne Couch haben können und drei Sessel dazu
} 
As with the expectation that Margit follow traditional female gender norms, there is an expectation that Lucie will also follow the requirements of socialist morality: she is expected to be thrifty and provide materially for her family. On the surface the scene addresses the problems of consumer goods in the GDR, which were both difficult to obtain and expensive, and in doing so criticises Honecker's move towards real existing socialism and the supposed increase in consumer production. However, at a deeper level, Lucie's story parallels Margit's: just as Margit is attempting to find self-fulfillment through love, Lucie is looking for fulfillment through new dresses and apartment furniture. But Lucie soon learns that this does not bring true fulfillment, breaking up with her boyfriend after the delivery of the armchair. At this point she calls Margit and cries "I, too, want to love, to really and truly love!" (Ibid). ${ }^{73}$ In this scene, Günther suggests that material goods do not themselves bring happiness, in spite of Honecker's emphasis on material production, and that true happiness and fulfillment requires something more that is not being realised under socialism, causing people to turn to materialism.

The most important message to be drawn from Der Dritte is that it portrays the persistence of traditional gender norms that confined women to the role of coy mistress at a time when women were gaining more sexual power due to the loosening of socialist morality. These gender norms are presented as creating a double standard, where women are emancipated in the workforce, but not in the private sphere. In terms of material desires, the film portrays material needs as a female vice that are regulated by socialist values of thriftiness and a stern male. It does this critically, commenting on the 
failure of socialism to provide for individual emotional fulfillment, which causes Lucie to turn to material possessions for fulfillment. Both statements on sexual and material desires point to the failure of socialist rhetoric and reality to meet socialist ideals, particularly with regard to women's emancipation and self-fulfillment. Die Legende, released one year after Der Dritte, also examines the contradiction between a woman's search for self-fulfillment and socialist reality, taking the critique presented in Der Dritte further, challenging conservative attitudes and jettisoning sexual constraints.

\section{Die Legende von Paul und Paula (The Legend of Paul and Paula)}

As the name suggest, Die Legende, directed by Heiner Carow, recounts the legendary love story of Paul (Winfried Glatzeder) and Paula (Angelica Domröse). The two first meet in a smoky disco, and although Paul is married, they begin a magical affair. Under pressure from society and family, Paul stays with his wife, and the romance ends after the tragic death of Paula's son, with Paula ceasing contact with Paul. Realising his mistake, Paul resolves to win Paula over once more, turning his back on material comfort, camping at her door, until she acquiesces. The two reunite briefly, only to be separated by the death of Paula during child birth.

Born in 1929 in Rostock, Carow was twenty years old when the GDR was founded. This year also saw him move to Berlin, in order to sit an entrance examination for DEFA. He made his first film, Sheriff Teddy, in 1957. Like Günther, Carow's film Die Russen kommen (The Russians are Coming, 1968) was banned at the Kahlschlag, and not released until 1987. His focus on "stories of the everyday and the feelings of the people" meant that he frequently came into conflict with the regime for the controversial themes his films addressed, such as domestic violence in Bis dass der Tod euch scheidet 
('Til Death Do You Part, 1978) and homosexuality in Coming Out (1989) (Carow qtd in Herlinghaus, 1983: 7). ${ }^{74}$

Die Legende, Carow's fifth film, was by far the most successful and well known film ever produced by DEFA, reaching more than three million viewers in the GDR and playing for months in sold out cinemas (Carow qtd in ibid, 1983: 25; Blunk, 1984: 236). Interestingly, director Carow and screenwriter Ulrich Plenzdorf began with the intention to make a film that people would "actually want to see" (Carow qtd in Rinke, 2006: 141). In creating such a film, they chose an aesthetic and characters radically different from the trends prevailing in East German cinema at the time. Absent from the film are the heavy-handed didacticism and ideal heroines of socialist realist cinema (still in evidence to a certain extent in Der Dritte). Instead the film features Paula as its heroine an apolitical, unskilled worker. As noted by one GDR reviewer, Die Legende was the first film since Dudow's films Frauenschicksale, Verwirrung der Liebe and Christine (1963) to feature such a protagonist (Blunk, 1984: 237). ${ }^{75}$ Importantly, this corresponded to the actual situation of women in East Germany, where the majority were employed in unskilled positions in traditionally female sectors, making Paula more identifiable to the average East German. It also reflects the move towards less ideal heroines, as Paula, much like Christa T, is a non-conformist. Furthermore, unlike Der Dritte where the romance between Margit and Hrdlitschka is of secondary importance to the didactic mission of the film, Die Legende centres on the love between Paul and Paula, and uses it to explore and subvert the pitfalls of socialist society. Reflecting this

\footnotetext{
74 "Ich habe mich in meinen Filmen mit den Geschichten des Alltags und mit den Gefühlen der Menschen beschäftigt"

${ }^{75}$ Interestingly, Heiner Carow was a protégé of Slatan Dudow, and, in his own words, learned "the kind of attitude needed to make a film" from Dudow (Carow qtd in Herlinghaus 1983: 18).
} 
Carow once stated "My theme is love. Love - it is said - inspires people, makes them creative, imaginative, human and friendly" (qtd in Herlinghaus, 1983: 51). ${ }^{76}$ This enables the audience to connect with the characters, particularly Paula, in a way that is purposefully obstructed through the Brechtian techniques used in Der Dritte. In a similar vein, the employment of fantasy elements differentiates Die Legende from the documentary realist style popular in Gegenwartsfilme of the 1960s.

Die Legende is not only a continuation of the developments made in cinema and literature, but also a consummate example of the innovations made in the period of cultural freedom during the early years of Honecker's rule. Die Legende drew from many of the dominant trends of the era, and developed them in a unique way. Firstly, the film's concern with the everyday, ideal and reality and its female protagonist places it within the group of films that began with Der Dritte in 1972. However, the manner in which the film emphasises Paula's subjectivity reflects a cinematic development similar to Christa Wolf's "subjective authenticity." One of the effects of focussing on the emotions and feelings of Paula, in particular her desire for true love, is that whereas Der Dritte focused on the contrast between socialist reality and socialist ideals, Die Legende examines the failure of socialist reality to live up to Paula's ideals. Emphasising Die Legende's status as the pinnacle of cultural innovation during this period is the increasingly harsh cultural reform that followed its release, which began as a consequence of its themes and popularity and culminated with the expatriation of folksinger Wolf Biermann in 1976. ${ }^{77}$

\footnotetext{
76 "Mein Thema ist die Liebe. Die Liebe - so sagt man - beflügelt die Menschen, macht sie schöpferisch, phantasievoll, menschlich und freundlich"

${ }^{77}$ Wolf Biermann was an East German folksinger and well-known dissident, critical of the SED regime. Originally born in West Germany, as a young adult Biermann, a committed socialist, moved to East
} 
Die Legende, like Der Dritte, uses the difficulties that Paula faces in fulfilling her sexual desires and search for love as a way to point to the gap between Paula's expectations of life, and the ability of socialist society to tolerate these expectations. The key mechanism depicting this gap is the juxtaposition between Paula's determined search to find true love, and the relationships of those around her, which are primarily based on material comfort. The main technique used by Carow to contrast Paula's search for true love with the materialist values of those around her is the framing of the film as a 'legend.' As such, the story gains an epic and magical quality that, according to Carow speaks to "the longings, the emotions of the viewer, and in doing so, also their possible experiences" (qtd in Herlinghaus 1983: 44). ${ }^{78}$ The legend form endows Paula as a type of saint, with magical qualities and frames her as morally superior to those around her (Rinke, 2006: 149). Paula's moral superiority is also highlighted in her nonconformism; she is not willing to settle for a marriage of convenience like those around her and instead waits for an honest love. The legend motif serves to underscore the absolutism of Paula's search for love. In doing so, the film portrays Paula's love and passion as a "liberating force," which frees her from the material constraints of conventional relationships (Ibid: 164). Aesthetically, the legend form allows an escape from the direct reflections of reality, encouraged by socialist realism and instead the film plays with fantastical elements far removed from socialist aesthetic norms. This

Germany. However, he soon ran into problems with the SED, who refused him Party membership and banned him from publishing music or playing publicly. In November 1976, the Politbüro of the SED used an officially sanctioned tour of West Germany to strip Biermann of his East German citizenship, effectively expatriating him to his native West Germany. The Politbüro's justified their action on the basis of remarks Biermann made on West German television. However, it is now known that the decision to revoke Biermann's citizenship was made prior to his first concert in Cologne.

78 “...entspreche ich eigentlich den Sehnsüchten, den Emotionen der Zuschauer und damit auch ihrem möglichen Erleben" 
liberation from convention and the norms of the collective was subversive, and indeed the film highlights this subversion through critical references to the East German state.

Furthermore, in framing the film as a legend, the narrative or 'story' element is brought to the fore. This has the effect of highlighting the journey and development made by characters throughout the film, most importantly Paul. As in Nachdenken über Christa $T$. where through remembering Christa $\mathrm{T}$ the narrator engages with her own past and ideals, and is transformed; in Die Legende Paul, who adopts a pseudo-narrator role, has a similar experience, forever changed through his relationship with Paula. In transforming the narrator, the audience is in turn also transformed and brought to a new enlightened place, especially given that Paul's transformation is key to the alternative form and criticism of socialism presented in Die Legende.

The story element is depicted during the opening credits, where the film is established as a modern day legend, with a Paul as the narrator. The film opens with the implosion and destruction of an old apartment building, during which the notorious GDR rock bank, the Puhdys play Wenn ein Mensch lebt (If a Person Lives), the lyrics reading:

If a person lives a short time, the world says he left to early If a person lives to a long time, the world says, it was time. My girlfriend is beautiful. When I got up, she was gone.

Don't wake her, until she stirs. I lie in her shadow.

Everything has its time. One stones to gather, cast them away.

Plant trees yesterday, fell them today. Time to love, to die, reason and fight. (Carow, 1973) ${ }^{79}$

These lyrics together with the visuals frame the film as a legend with a narrator, as well as establishing the contrast motif that will be drawn throughout the film between

\footnotetext{
${ }^{79}$ Wenn ein Mensch kurze Zeit lebt, Sagt die Welt, dass er zu früh geht. Wenn ein Mensch lange Zeit lebt, Sagt die Welt, es ist Zeit. Meine Freundin ist schön, Als ich aufstand, ist sie gegangen. Weckt sie nicht, bis sie sich regt. Ich habe mich in ihren Schatten gelegt. Jegliches hat seine Zeit, Steine sammeln, Steine zerstreu'n, Bäume pflanzen, Bäume abhau'n, Leben und Sterben und Streit.
} 
socialism, materialism, and true love. Firstly, the lyrics of the song bear a resemblance to Ecclesiastes 3;

To every thing there is a season, and a time to every purpose under the heaven: A time to be born, and a time to die; a time to plant, and a time to pluck up that which is planted;

A time to kill, and a time to heal; a time to break down, and a time to build up; A time to weep, and a time to laugh; a time to mourn, and a time to dance; A time to cast away stones, and a time to gather stones together; a time to embrace, and a time to refrain from embracing. (King James Bible, Ecc. 3: 1-5)

This biblical comparison underscores the legendary character of the film, framing it as a moral tale. During the song the camera remains on the imploded building with cranes seen in the background, suggesting that this is an area under development. The shot soon cuts to an upward view of an apartment block, where a man (Paul) is throwing objects out of the window, onto a pile of discarded furniture below. Toward the end of the song the shot moves to a streetscape where a group of construction workers stand laughing, looking past the camera. The next shot explains what the workers were looking at: Paul stands holding an oval photo frame across his body, the photograph obscured by Paul's hand, which is resting over his heart. As Paul moves his hand, a photograph of Paul passionately embracing Paula is revealed, and the title of the film comes on screen, inscribed within the frame. This sequence establishes Paul as a narrator-figure telling the viewer the legend of Paul and Paula. It is only at the end of the film, when the Puhdys song is played a second time and the shot reveals the Berlin skyline, dotted with cranes and construction, that the audience realizes the opening titles were a 'flash forward,' where Paul is clearing out Paula's apartment after her death (Feinstein, 2002: 206). 
In regard to the motif of contrasts, the scene juxtaposes socialist progress with Paul's individual development, foreshadowing the changes that Paul experiences as a result of his relationship with Paula. The images of the falling buildings refer to the housing project launched by Honecker in the 1971 Five-Year Plan, and also, on a symbolic level, a construction site stands for the processes of social progress under socialism. This is then contrasted with Paul, who is rejecting these material advances, throwing plates and baskets out of the apartment window. The only object we see Paul with is the photograph of he and Paula embracing; Paul seemingly choosing love, as symbolised in the photograph, over material comfort. Importantly, this prefigures the decision that Paul makes to be with Paula, and the personal growth that he makes during the film; turning away from a prestigious career and salary for true love. Furthermore, the construction workers, because of their role in the rebuilding of East Germany, symbolise the vanguard of socialist progress. As such, their laughing at Paul indicates that Paul's adherence to love over material possessions is passé within the context of socialist progress. This contrast works to emphasise Carow's attitude that socialist 'progress' is actually regression, when compared to Paul's positive growth. This message is also highlighted in Paula's death, in that Paul's personal development is only portrayed in the context of Paula's death, suggesting that it is only through her death that he was able to grow, thus underscoring the regression brought about by socialism as practiced in East Germany.

Paul's radical transformation during the film is highlighted in the contrast between Paula's life as a single mother, and the 'fairytale' marriage of Paul and Ines, and the comparison between the values that Paul and Paula ascribe too. Whereas Paula 
adheres to true love and will tolerate nothing less, Paul is portrayed as materialistic and engendering outdated bourgeois values. This is quickly established by contrasting a sequence focussing on Paul's relationship with Ines, the woman he comes to marry, with one centred on Paula and her relationship with Colly, the man with whom she conceives her second child. From the outset Paula is portrayed as searching for true love, refusing the advances of the wealthy, but elderly, Reifen-Saft (which translates both as 'Tyre Man-Saft' and comically, 'ripening juice'). Furthermore, she is sexually assertive and passionate. Paula obviously eyes Colly from the moment she meets him, and leads the way into his bedroom. However, upon returning home from the hospital, after almost dying in childbirth to his son, Paula discovers Colly cheating on her. Immediately, she kicks him out of her apartment, slapping and pushing him away, throwing his clothing down the stairwell.

Such passion stands in stark contrast to the contrived marriage of Paul and Ines, which in comparison to Paula's assertiveness in relationships is portrayed as outdated within the new gender order. The two take on traditional gender roles, where Paul is the provider, the protective dominant male offering Ines his coat, and Ines is the object of beauty. Ines is first seen perched at her family's carnival shooting range, smoking and wearing a revealing outfit as she 'works' at attracting young males to the game, and throughout the film she is often seen posing herself. In describing Paul and Ines' relationship, Carow stated that it was "one based on the capitalist relationship of man and woman (husband and wife), which is likely to deform and degenerate both. The antithesis, so to speak, of the way of living expected in our society" (qtd in Herlinghaus, 
1983: 53) ${ }^{80}$ In suggesting that socialism should have generated new forms of love based on equality and respect, Carow is sending a similar message to the central theme of Der Dritte.

In contrast to Paula's search for true love, it is clear from their first date that Paul and Ines' relationship is loveless and based solely on material concerns. It is only after learning that Paul has a guaranteed job that will pay him 800 Mark a year that Ines allows Paul to kiss her, revealing her true material concerns. Moreover, Paula's honest reaction to Colly's cheating is a total contrast to Paul's reaction to discovering Ines in bed with a naked man when he returns home from military service. Rather than end the marriage, Paul falls for Ines' crocodile tears. After 'reconciling' the two lay in bed naked, with Paul promising to be a better husband, a task he measures in providing for the material wellbeing of Ines: "We'll sell the old junk, or throw it away. Everything will be new, Ines, the whole place. You'll be amazed" (Carow, 1973). ${ }^{81}$ Again Carow is highlighting the falsity of the love between Paul and Ines, as it is merely a marriage of convenience based on Paul's lust for Ines, and Ines' material desires.

Although Paul's marriage is portrayed critically as not belonging to the ideals of socialism, it is Paula whose search for true love does not conform to life in East Germany. Furthermore, her hard life appears as punishment for not choosing the prudent and materially beneficial match with Reifen-Saft. After Colly leaves, Paula is left as a single mother once again, working at a state-run grocery store, known as a Handelsorganisation, continuously harassed by customers. In one scene, she is depicted

\footnotetext{
80 "Eine auf kapitalistischen Verhältnisse beruhende zwischen Mann und Frau, die dazu angetan ist, beide zu deformieren und bis zum Tierischen zu entstellen. Gewissermassen die Antithese zu den in unserer Gesellschaft notwendigen Lebensformen."

81 "Den alten Plunder verkaufen wir oder wir schmeissen ihn weg. Alles wird neu, Ines, die ganze Wohnung, du wirst staunen"
} 
returning home from work to find a pile of coal dumped in front of her apartment building. Paula then spends her evening carrying buckets of coal up to her apartment, gradually becoming wearier; stretching her aching back and wiping her coal and sweat smeared face. All the while, she is surrounded by people coming and going from the cinema near her building. The film then cuts between images of Paula filling her coal buckets to shots of movie posters advertising the French court drama Angélique and shots of happy couples nearby. This sequence points to Paula's yearning for fairy-tale happiness and true love. ${ }^{82}$ After moving the coal, Paula exhausted, expresses her dissatisfaction, complaining: "To bed at nine. There must be more than sleep. Work. Sleep and work again. I'm 23 years young" (Ibid). ${ }^{83}$ She then pours herself some schnapps before continuing. As if in reference to marriages like Paul's, Paula then criticises those that marry without love, saying "God, if only they wouldn't pretend you can do without it [love]" (Ibid). ${ }^{84}$ In using the pronoun 'they' Paula is framing these loveless relationships as the expected norm, one to which she does not conform. However, exhausted from her hard day of work, Paula determines to marry Reifen-Saft, claiming that she can "manage" without love, in order to gain the material benefits that would come with marrying him:

I could have the tireman. He's ready and able. One word and I have him. With a registry and Church bells. Nobody would dump more coal in front of the door. My children would have a father. He's well preserved. At least I'd be left in peace. Over, Done! (Ibid) ${ }^{85}$

\footnotetext{
${ }^{82}$ This sequence has also been linked to a critique of the importation of Western films, whose portrayal of daily life did not match the reality of life in East Germany (Rinke, 2006: 160).

83 "Um neun schlafen! - Es muss doch auch noch was anderes geben also schlafen. Arbeiten. Schlafen und wieder arbeiten! Mit dreiundzwanzig Lenzen!"

84 "Herrjott, wenn die doch bloss nicht so tun taten als ging's nicht ohne das!"

85 "Dabei könnt ich den Reifenfritzen haben. Der steht doch Gewehr bei Fuß. Ein Wort, und ich hab ihn, und zwar mit Standesamt und Kirchenglocken, und keiner schüttet mir mehr Kohlen vor die Tür, und
} 
This scene, like Der Dritte, questions the socialist precept that economic independence from men will allow women to marry for love. Paula's decision to marry Reifen-Saft, as well as Ines' marriage of convenience to Paul both illustrate the persistence of bourgeois and capitalist gender norms that cause women to marry for their economic security.

In the fashion of a legend, fate does not allow Paula to marry Reifen-Saft, as that evening she meets Paul at the disco and falls in love. The effect of this love on Paula is magical and liberating. The morning after they meet, Paula skips and plays with her children as they walk to school; this joie-de-vivre contrasting with the Paula who was carrying coal the night previous. Once at work, Paula is transferred to work at the cash registers where her good mood and sense of humour magically transforms the angry mob at the check-out and her disgruntled co-workers. As she makes her way to the crowded registers she stands on a chair and pronounces her check-out for people under thirty only. The film then cuts to close-ups of her co-workers faces, who are all smiling, as if having 'caught' Paula's good mood. Paula then begins singing a bawdy song as she rings customers through, and eventually the crowd joins in singing the refrain.

Despite liberating Paula from her dreary life, Paul is still confined to his blind conformism and outdated attitudes. This is most clearly illustrated when Paul and Paula go on their first date to an open-air concert of Beethoven's violin concerto. The camera focuses on Paula's face, as she is captured by the music. She stares lovingly at Paul, who pays no attention, oblivious to her inner longing. As the music builds to a crescendo Paula mentally undresses Paul, shown in a series of shots of Paul in various states of undress, until finally he is sitting with his shirt unbuttoned wearing a locket with 
Paula's photograph. Not only does this show Paula's sexual desire for Paul, as she holds him in her gaze, but also symbolically her desire for the man beneath the clothing, "underneath the stiff façade of a government official" (Rinke, 2006: 163). Almost uncontrollably, Paula cuddles up to Paul, at which he pushes her away telling her "Not here," admonishing her for her inappropriate behaviour. Paul is unable to let go of the notions of bourgeois respectability that expect him to be measured in his behaviour. In particular, he faces pressure at work to remain married, telling Paula "I can't afford a divorce in my position. There's no regulation, but it's a rule" (Carow, 1973). ${ }^{86}$ Rather than being true and honest, Paul suppresses his feelings for the benefit of propriety and his son. In discussing this scene, Carow stated that Paula "shows...how deeply she can experience, provoked through art. What can Paul do? These are real contradictions, collisions" (qtd in Herlinghaus, 1983: 51). ${ }^{87}$

Nowhere is Paul's blind conformism clearer than when Paula visits him at a work function the day after the two spend a magical night together. Paula dressed in disguise, arrives at the government party to find Paul's wife on display, dancing and flirting with foreign officials while being ogled by Paul's co-workers, in a scene reminiscent of the beginning of the film when she was at 'working' the carnival. Here, Carow is suggesting that the out-dated objectification of women, which he criticises through the relationship of Paul and Ines, is an institutionalised practice: Ines is being used for her looks by the government to ensure good business. Once Paul recognises Paula, he is annoyed and full

\footnotetext{
86 "Und ich...kann mir keine Scheidungsgeschichte leisten in meiner Funktion. Es gibt da keine Dienstvorschrift, aber es ist so."

87 "Sie zeigt in dieser Szene, wie tief sie erleben kann, angeregt durch die Kunst. Was kann hier Paul? Das sind doch echte Widersprüche, Kollisionen"
} 
of self-importance, taking her outside to speak privately, where he condescends to her, saying:

Paul: You're too...too.... What you want doesn't work.

Paula: And was it that?

Paul: You want everything or nothing.

Paula: So what!

Paul: Yes, but there are duties, that one has to follow. Nobody can do as they please. For the time being.

Paula: And simply being happy?

Paul: Not at the expense of others

Paula: Then when? (Carow, 1973) ${ }^{88}$

This scene demonstrates Paul's unwillingness to move away from rigid conformity: his 'obligations' to career and wife reign supreme over his own happiness, and has commonly been interpreted as symbolic of the confining nature of socialist society. On one hand, representing traditional SED rhetoric, Paul's statement "but there are duties, that one has to follow. Nobody can do as they please. For the time being," refers to the collective: each individual has responsibilities towards the greater good, even if that means sacrificing their own personal desires. In contrast, Paula's defiant question "and simply being happy?" probes the issue of where happiness and individual desires fit within socialist society. The conversation succinctly encapsulates the fundamental difference between Paul and Paula: whereas Paul will deny his desires, in favour of what is expected of him, Paula will only accept true and honest love. Importantly, by painting Paula in such a way, Carow is highlighting her moral superiority over Paul, thereby

${ }^{88}$ Paul: Ja, du bist zu...zu...Was du willst, geht nicht Paula: Was will ich denn schon.

Paul: Alles oder nichts willst du!

Paula: $\mathrm{Na}$, und?

Paul: Ja, aber es gibt Verpflichtungen, denen muss man nachkommen. Keiner kann immer nur das machen, was er will, vorläufig ist das so.

Paula: Und einfach glücklich sein?

Paul: Blo $\beta$ nicht auf Kosten anderer

Paula: Und wenn doch? 
critiquing and subverting the structures of government and conformity, which Paul symbolises.

However, Paul has been unknowingly transformed by the magic of Paula's love, its subversive potential highlighted when Paul eventually succumbs to his feelings, turning his back upon the rigid conformity expected of him, undermining the structures he once stood for. After Paula leaves Paul at the work function she sinks into depression, worsened by the death of her young son. She superstitiously reads his death as punishment for her affair with Paul, which caused her to neglect her maternal duties. When Paul attempts to see her she refuses to answer the door having decided that she will marry Reifen-Saft. But Paul has been transformed, finally acknowledging his own feelings for Paula. In a test of love typical of the legend form Paul instead of returning to his family, work and conformity camps on Paula's doorstep: his subversion of the norms and regime he once upheld shown symbolically in his use of the Party newspaper Neues Deutschland (New Germany) as a mattress. His transformation from rigid conformist to disciple of love is shown in his new attire of jeans and a sweatshirt with stubble setting in, replacing his brown suit and tie, looking more like a hippy than a government employee. These transformations also demonstrate Paul's gradual move away from material possessions.

Paul's final transformation closely follows the theme of a legend. His love for Paula is tested when his colleagues attempt to bring him back to 'normal' and reunite him with Ines. Quickly seeing the farce of their marriage, Paul, dressed as Prince Charming marches over to Paula's apartment building and breaks through her door with an axe, heroically proclaiming "Paula. I'm coming," as though she were a damsel in 
distress (Ibid). ${ }^{89}$ After he breaks the door, he strides gallantly into Paula's bedroom sweeping her into his arms. Paula's initial cries of 'No' soon turn into passionate kisses. With this, Paul's transformation is complete: he has turned his back on the conformity and materialism of his previous life and marriage in favour of a more honest and passionate love. The change in Paul summed up by Paula, who tells her doctor "Paul is Paul and Paula" (Ibid). ${ }^{90}$

Having won Paul and achieved fulfillment through finding love Paula aims at “complete fulfillment" (Rinke, 2006: 168). However, individualised fulfillment outside of the collective cannot be tolerated within East German society, and as such, Paula must die in order to achieve it. Despite being told that she will likely die in the delivery room Paula decides to have Paul's child: this ultimate act of self-determination making Paula a martyr of her undying love for Paul. Paula's death can be seen similarly to Christa T's, in that her quest for self-fulfillment and actualisation cannot be realised within this particular reality. Such quests are too individuated, taking people away from accepted collective conformity. Paula's quest for her ideal can only be realised in death. The tension between Paula's ideal of true love, based upon self-determination, and reality is summed up by her doctor, who tells her: "You aren't a child anymore Paula. There are things that don't happen. If you were to understand any philosophy, I'd say: Ideals and reality never coincide. There is always a gap" (Carow, 1973). ${ }^{91}$

Importantly, Paula's death adds to the subversive elements of the film and to its critique of the East German regime. Film officials in the GDR opposed Paula's death

\footnotetext{
89 "Paula. Ich komme!"

90 "Paul ist Paul und Paula"

91 "Du bist doch kein Kind mehr. Es gibt eben Dinge, die nicht gehen. Du kannst nicht alles haben. Wenn du was von Philosophie verstehen würdest, würde ich sagen: Ideal und Wirklichkeit gehen nie übereinander. Ein Rest bleibt immer."
} 
because in the tenets of socialist realism death was only to be portrayed if it served a heroic or political purpose, such as death on the battle field or for a political cause (Knietzsch qtd in Rinke, 2006: 169). Although Paula does not die in this manner, her death is not without political statement. As argued by scholar Rudolf Jürschik, Paula's death leaves the audience with "the impression of an unfulfilled - unfulfillable - quest for happiness" (qtd in Rinke, 2006: 170). ${ }^{92}$ Although her spirit lives in Paul, it is only in this modified form that it can exist. East German scholar Irene Dölling argues that Paula's death takes back and "tames" her pursuit of individual happiness (2001). However, this argument ignores the true cause of Paula's death, namely, her choice to pursue ideal over social reality through her decision to have Paul's child. Furthermore, Paula's death is necessary to frame the story as a legend; only through her ultimate sacrifice is her "saint's courage and moral superiority" proven (Rinke, 2006: 171). Paula's death, therefore, works to subvert the East German regime by highlighting the impossibility of her search for happiness. At the same time the film inspires hope through Paul's transformation that change is possible. In presenting this transformation, Carow is offering the viewer a more humanistic alternative to SED socialism. Given that Paul's transformation is due to his interaction with Paula this alternative is constructed as female.

But what of sexual desire? Paula's sexual desires, chiefly portrayed in the film's sex scene, add to the subversion and criticism of the SED. This scene also elaborates upon Carow's alternative to socialism further emphasising the scene's subversion. By linking Paula's sexual desires with subversion the film perpetuates the notion that women's sexual desires, when predicated upon autonomous needs for self-fulfillment

92 "Es bleibt der Eindruck von einem unerfüllten - unerfüllbaren - Glücksanspruch" 
and love, are destabilising and unacceptable within East German society. The sex scene begins with Paul entering Paula's bedroom wearing his combat group uniform; he has skipped combat training in order to be with Paula, symbolically choosing individual happiness over collective responsibilities. Naturally, this scene was questioned by GDR film officials, with Hager's office asking "Should the scene 'following the combat group training' be read as: we are casting off all the vestiges of social duty; we wish to be alone in our happiness?" (qtd in ibid: 152). After Paul arrives, the shot shows Paula's bedroom transformed into idyllic island paradise: yellow flowers are strewn over the room and a lavish feast is set out on the bed. Paula, wearing a short white slip decorated with flowers, presents Paul with a crown of flowers and invites him to the island bed, suggestively sitting with the feast spread between her open legs. During the meal, conversation turns to Paula's family history. Paula comes from a family of bargemen, where all women are named Paula, after the barge they travelled on. However, her family are deceased all the men having died. This image of Paula's family as transient river dwellers, steeped in tradition forms the basis for Carow's alternative vision of socialism, as it stands in stark contrast to the accepted way of life, typified in Paul's marriage, structured around material possessions.

During the scene, Paula is very much the seductress, making her sexual desires known to Paul. After talking about her family, Paula quickly changes modes, fanning herself and suggestively saying "Hot, isn't it?," as she leans forward, tearing the flowers from the slip, all the while staring at Paul (Carow, 1973). ${ }^{93}$ Helping Paul take off his shirt, Paula playfully grabs the salt and pepper shakers, preparing Paul "for consumption" (Rinke, 2006: 152). This role reversal, where the man is the sexual object

93 "Heiss, oder?" 
was not appreciated by GDR critics, with Horst Knietzsch the chief editor of Neues Deutschland stating "The film contains impressive scenes which give us a glimpse of the rich inner beauty of Paula. However, it is biological interests that are predominant" (qtd in Rinke, 2000: 58). Such criticisms are not dissimilar to those faced by Der Dritte and Margit's open discussion of her sexual desires; if anything, Die Legende takes things one step further in actually portraying a sex scene and female nudity.

As the scene and intimacy progress, the film mixes critical references to everyday life in the GDR with fantasy elements of Paula's family envisioned in Paul's dream. This dream begins with Paul hallucinating that three of his colleagues are in the bedroom, posing as musicians, to spy on he and Paula. Paul's hallucination points to his concern that his career would be jeopardised if his affair was discovered, and to the selfpolicing mechanisms used by the Party to ensure conformity. As aptly captured by Rinke the scene is "a surrealist allusion to the omnipresence of surveillance in the GDR" (2006: 152). In this respect, it is similar to the authoritarian conceptualisation of socialist morality purported by Herzog, discussed in the first chapter, where the Stasi were used to ensure conformity to socialist norms. The scene is then fantastically transported to Paula's family barge, where Paul and Paula are in bed sailing down the Spree with the Puhdy's song Geh zu ihr (Go to Her) playing on the soundtrack. The lyrics and gravelly male voice of the song underscore the sexual atmosphere, singing "Go to her and unfurl your kite! Go to her, you cannot live on bread alone! Hey, hey, fly you're kite man! Hey, hey, hey, go to her!" (Carow, 1973). ${ }^{94}$ As Paul and Paula sit in the bed on the barge, Paul is dressed in an open white shirt, lace vest and silver necklaces, looking like

\footnotetext{
94 "Geh zu ihr und lass deinen Drachen steigen! Geh zu ihr, denn du lebst ja nicht vom Moos allein! Hey, hey, deinen Drachen! Hey, hey, hey geh doch zu ihr!"
} 
a gypsy prince. Paula meanwhile, is naked, except for a wedding veil, draped across her body. Climbing out of the bed, Paula introduces Paul to her assembled family, generations of which have appeared on the barge, bowing to them and saying "This is Paul and I have a son too" (Ibid). ${ }^{95}$ The singling out of Paul and her son refers to the lack of male heirs, causing Paula's family to die out. In this respect Paul represents the regeneration of something ancient. Feinstein links this to an alternate understanding of time, in contrast to the transcendental view espoused by the Party: whereas Paul stands for the model of socialist progress, Paula symbolises "an understanding of life emphasising cyclical renewal rather than endless horizons, tradition instead of progress" (2002: 209). Importantly, these concepts of love, tradition and regeneration all refer to Carow's alternative vision of socialism, one that is based on humanist values, rather than material progress.

Supporting these themes of renewal and tradition are the 'pagan' rituals performed at the wedding that Paul dreams about, noting that weddings are ceremonies of union and reproduction. In the first ritual Paula is seen on top of a banquet table, where her ancestors tear at her veil as she tries to get away from them, finding refuge on the bulkhead. Paul, in the next ritual, is delivered to Paula, carried by her female relatives. Unfortunately, this scene was viewed by some critics as pornography, prompting Carow to comment:

It is often misunderstood. It should express much more, for example, the joy of love. When everyone tears away her veil, and she sits beckoning to Paul and the old women behind him - it is not a chaste concealment. The public are watching.

95 "Das ist Paul! Und einen Sohn hab ich auch!" 
There are such old traditions, and there is something vital about them (qtd in Herlinghaus, 1983: 52 $)^{96}$

Almost in anticipation of such a reaction, Carow criticises the hypocrisy of the East German regime. As Paula sits on the bulkhead, her breasts clearly visible through the thin veil, two of Paul's co-workers look on. Shocked, one comments "That's pornography," with the other telling him to "Look the other way" (Carow, 1973). ${ }^{97}$

Obediently, he covers his eyes and walks away turning his back on the scene before turning around once again to sneak another look.

Fantasy elements are key to this sequence, as they emphasise the boundless and eternal nature of Paula's love. Paula's love is so great that it cannot be captured by traditional aesthetics, instead taking place on another plane of existence: Paul's dream. Similarly, Paula's traditional way of life can no longer exist in the modern East Germany, illustrated through the death of her family. Importantly, it is Paul's dream, not Paula's, suggesting that both Paula's love and lifestyle are so contrary to East German society that they can only exist in a moderated form, whether that be in Paul's dream, or embodied in Paul himself, after Paula's death. In this respect, sex acts as a liberating force, freeing Paul from his life of conformity and emphasising the subversive potential of Paula's love and sexual desires. Furthermore, her desires are focused within the private sphere, completely unrelated to the collective. Indeed, this aspect of the film was heavily criticised with Neues Deutschland complaining that Paula's

unboundedness in the pursuit of purely personal desire, which defies all social criticism, opposition, rules of conduct and conventions and which, in Paula's

\footnotetext{
96 "Sie wird oft missverstanden. Sie soll doch mehr ausdrücken: z.B auch die Liebesfreude. Wenn da alle ihr den Schleier wegreissen und sie dasitzt und dem Paul winkt und die alten Weiber dahinter - das ist eben keines keusches Verstecken. Die Öffentlichkeit guckt zu. Es gibt solche alten Brüche, das hat auch etwas Vitales."

97 "Das ist doch porno." "Sieh doch weg."
} 
case, is focused on personal happiness which isolates itself from the common good." (qtd in Rinke, 2006: 157) ${ }^{98}$

Such desires, because of their seclusion from the collective, were subversive and could not be tolerated in the GDR. As such, Paula dies and the film points not to the regulation of women's autonomous sexual desires, but instead to the impossibility of selffulfillment through love.

Material desires, on the other hand, are presented as the 'opiate of the masses:' material comfort is provided on the basis of conformity and adherence to the Party. Similarly to the way that Lucie in Der Dritte uses material goods to bring a sense of fulfillment to her life, Paul measures his success and love through the attainment of material goods. Given Paul's role as a symbol for socialist conformity, the film portrays material advancement as an essential part of socialist progress, and as a pacifying tool used to encourage conformity. This is clearly portrayed in the contrast between Paul and Paula. Paul, ever the loyal Party official, lives in a Neubau, in an apartment decorated with kitsch decor, with the camera at one point lingering on a portrait of flying geese in his living room, alluding to the outdated and bourgeois nature of their marriage as such kitsch was seen as a waste of collective resources (Rubin, 2006: 163). In contrast, Paula is linked to an older generation and values love over material possessions. This is depicted through scenes such as the love feast, which emphasises tradition over progress, and in Paula's neighbours, shown throughout the film watching over Paula, who are all elderly. Furthermore, in comparison to Paul's modern apartment, Paula lives in an older building without modern conveniences, where the sounds from the nearby cinema can

\footnotetext{
98 'Unbedingtheit rein persönlichen Wollens, die allen gesellschaftlichen Widersprüchen, Widerständen, Verhaltensvorschriften und Konventionen trotzt und die sich bei Paula auf das persönlichen Glück richtet, das vom gesellschaftlichen Wohl isoliert ist."
} 
easily be heard through the walls, her menial job not well paying enough for a newer apartment. It is only when Paula considers conforming to the norm - by marrying Reifen-Saft - that her material situation has the possibility of improving: when visiting Saft's datsche (cottage) Paula is stunned at its facilities; a fully furnished bathroom and kitchen. At the same time, while material comfort is linked to conformity, Paula's status as a figure of subversion, and her choice of love over materialism, highlights the rejection of material comfort, and by extension, socialist progress as subversive.

The film does gender material desires through the character of Ines, whose primary interest in Paul is material. However, rather than posing her material desires as a feminine vice, Carow presents them more forgivingly as a learned behaviour. As previously discussed, Ines was used by her family to encourage business at the carnival, in a similar manner as her mother was used when she was younger (Carow qtd in Herlinghaus 1983: 53). Further still, when her parents come to visit her and Paul, it is revealed that they were put out of business for fraud and tax evasion. In this respect, Ines' materialism is understandable, and is reflected, as Carow suggests, in the bourgeois way she interacts with Paul.

The manner in which Die Legende juxtaposes material desires with Paula's quest for fulfillment through love poses a fundamental philosophical question about life, values and the concept of progress. Carow hints at this question when Paula's doctor tells her "Ideals and reality never coincide. There is always a gap" (Carow, 1973). ${ }^{99}$ With this statement, idealism, embodied in Paula is contrasted with socialist reality, portrayed through the film as based in materialism, inferring that Paula's values and

\footnotetext{
99 "Du bist doch kein Kind mehr. Es gibt eben Dinge, die nicht gehen. Du kannst nicht alles haben. Wenn du was von Philosophie verstehen würdest, würde ich sagen: Ideal und Wirklichkeit gehen nie übereinander. Ein Rest bleibt immer."
} 
ideals are at odds with socialist reality. This comparison is also made in the love scene, where Paula is linked to cyclical notions of time, rather than the linear progression promoted by the SED. The fantastic setting of the love scene indicates that Paula's way of life cannot exist within socialism. In framing the film as a legend, with a moral lesson, Carow is suggesting that there is something wrong in the socialist way of life as practiced in East Germany, namely, in focussing on material progress, it has lost touch with its pure ideals. In highlighting Paul's transformation throughout the film, Carow is suggesting an alternative, somewhere between Paula's absolutism and conformism.

Die Legende, like Der Dritte, was heavily criticised by East German officials. Not only did the film address Paula's sexual needs, but also featured nudity, a topic of much concern since the scandal involving Dudow's film Verwirrung der Liebe. The film further subverted the East German state through portraying the potential of Paula's love (and sexual desires) to take Paul away from the collective. Her desires, based upon an autonomous need for fulfillment, are beyond regulation and simply cannot exist in the GDR; they belong to another time, outside the socialist understanding of history. This contrasts with the use of material incentives to reward conformity, which are almost portrayed as anti-socialist, and as encouraging degenerate capitalist relationships, like Ines and Paul's marriage, to be the norm.

\section{Conclusion}

In spite of its controversy, on the morning of its release, Honecker reviewed Die Legende, and in the spirit of "no taboos" allowed it to be released. However, soon afterwards, the reigns of cultural policy would be tightened anew, largely due to the 
widespread popularity of Die Legende, with one DEFA dramaturge, Klaus Wischnewski, commenting in 1991 that:

The SED's leadership's attitude towards the arts was characterised, on the one hand, by mistrust, even hate of individuality, of ways of thinking and looking at things that were 'alien' to the class struggle, and, on the other hand, by hear of uncontrollable effects. Nothing was quite as unsettling as the spontaneous mass appeal of films such as The Legend of Paul and Paula. (qtd in Rinke, 2006: 41).

As a consequence, Honecker modified his "no taboos" stance, stating that films that focused on

the loneliness and isolation of the individual from society...their anonymity in relation to the social context, shows us clearly that the fundamental attitude of such works is antagonistic towards socialist expectations of art and literature [sic] (Honecker, qtd in ibid).

This meant that films, like Der Dritte and Die Legende, that featured heroines on the margins of GDR society could no longer be tolerated. The period of cultural restriction came to a climax in 1976, when East German singer Wolf Biermann was expatriated to West Germany. In spite of this, a second wave of liberalism in the late seventies and early eighties allowed for the production of critical Frauenfilme, such as Bis dass der Tod euch ('Til Death Do You Part, 1979), SOLO Sunny (1980) and Das Fahrrad (The Bicycle, 1982), many of which featured non-conformist characters and dealt with issues of ideal and reality.

Der Dritte and Die Legende were essential to these later productions. Der Dritte was one of the earliest films to take advantage of Honecker's "no taboos" period and blazed the path for critical portrayals of women's issues and the thematic concern with ideal and reality in cinema. Die Legende, on the other hand, stood at the pinnacle of this era of Frauenfilme, both for its popularity, unique use of aesthetics and in its subversion 
of the East German regime. Importantly, both films use women's sexual and material desires as a vehicle to comment on the ability of the GDR society to tolerate the protagonist's ideal. Furthermore, the protagonists, Margit and Paula, use these desires as a mechanism to achieve fulfillment. Margit's search for fulfillment through love faces difficulty when confronted with persisting gender norms, therefore she must regulate her own sexual desires in order to reach her goal of finding her Third Man. Paula's desires, meanwhile, are too non-conformist and subversive to exist under socialism, they are beyond regulation. Material desires, on the other hand, are presented as an alternative path to fulfillment; the path chosen by Lucie and Ines. Whereas in Der Dritte material desires are presented as a female vice, Die Legende portrays them as a mechanism to ensure conformity within the socialist regime.

Finally, both films subversively question the success of the socialist project, not on the public level, but rather in the private sphere. Der Dritte focuses on the success of women's emancipation, and asks whether public emancipation has been matched by private freedom from gender norms. Die Legende asks a far more fundamental question; whether the quest for individual private happiness can be realised under socialism. This thematic concern with socialism in the private sphere reflects a 'domestication' of socialism, fitting for that stage of socialist development in the GDR: the ideological battle and struggle to implement socialism of the fifties and sixties was over, and an entire generation, indeed Paula's generation, had grown up and been socialised under socialism. The questions posed by Günther and Carow, and to a certain extent by Wolf in Nachdenken über Christa T., point to a domesticated and feminine form of socialism, 
in contrast to the patriarchal SED, where socialist development is taken to the next level, in to the subjective sphere of desire, longing, and emotion. 


\section{Conclusion}

There was also a totally normal life in this state too, that followed its own rules, and so easily followed its own routines - an everyday (Müller, 1999: 20) ${ }^{100}$

Having quit her monotonous job at a metal plant, single mother Susanne finds it difficult to make ends meet. The restrictions of motherhood mean she cannot accept similar menial jobs that require she work weekends, and the one well-paid white collar job she finds requires her to travel, also impossible as a single mother. When her young daughter Jenny falls ill and her father refuses to pay advanced child support, Susanne, acting on the advice of her friend, falsely reports her bicycle missing, in order to claim the insurance money from the East German state.

Susanne, the protagonist of Evelyn Schmidt's film Das Fahrrad (The Bicycle, 1981), represents the "misfit"; the last stage of development in Rinke's analysis of East German Frauenfilme. Rinke has argued that while depictions of women began as ideal socialist heroines, designed to instruct women on the expected mode of behaviour under socialism in the fifties and sixties, between 1972 and 1982, depictions of women travelled from "socialist models," as in Margit from Der Dritte, to "private dreamers," like Paula from Die Legende, and finally to "rebels and misfits" (2006; 1999). This categorisation indicates that within almost thirty years between the release of Frauenschicksale in 1952 and Das Fahrrad in 1981, depictions of women had changed radically. Susanne is miles away from the ideal socialist heroines of the fifties and sixties. She has little education, is apolitical and spends her evenings with her counterculture friends in a disco, drinking and taking drugs, and she defrauds the state. Unlike

100 "Auch in diesem Staat gab es ein ganz normales Leben, das nach vertrauten Regeln und so ganz selbstverständlich ablief das seine Routinen hatte - eben 'Alltag."” 
Renate in Frauenschicksale, Susanne is not offered redemption through socialism, but rather when her fraud is discovered she must pick herself up and start again. The change in depictions of women from ideal to misfit belongs to the development of a subjective female voice within East German society started by Christa Wolf in Nachdenken über Christa T. and furthered by female filmmakers, such as Evelyn Schmidt. These changes are even more startling considering the negative state attitude towards feminism as a bourgeois concept, which as a result meant that the GDR never experienced a feminist or sexual revolution, as in the West (Herzog, 2008).

Given this why was there a development in depictions of women, and how did this occur? Both Feinstein and Rinke have argued that depictions of everyday life and women in East German Gegenwartsfilme reflected social and political trends developing in the GDR. During the years of consolidation, in the fifties and sixties, portrayals of everyday life acted as instruction manuals to guide the newly socialist citizenry. This was particularly the case for depictions of women, who were the vanguard of the new socialist generation both for their roles as mothers, but also due to the role women played as indicators of the success of socialism. These films were based in the aesthetics of socialist realism, portraying positive heroes and storylines set in the industrial world. The Eleventh Plenum of 1965, or Kahlschlag, put a grinding halt on the brief period of cinematic innovation created after the building of the Berlin Wall in 1961. Specifically targeting DEFA, twelve films were banned, and in the period following the Kahlschlag, East German cinematic productions were largely genre films, and films following the norms of socialist realism. However, as discussed, 1971 was a landmark year; the SED leadership changed from Ulbricht to Honecker, inviting a change in Party rhetoric, 
allowing for an increased focus on the individual and a period of liberalised cultural policy. During this period films began increasingly focussing on everyday life and the ordinary experiences of life in East Germany, and in doing so presented messages and themes critical of the SED and its brand of socialism. Depictions of women reflected this trend, with the ideal socialist heroines of yore being replaced by more 'realistic' female protagonists, who, in contrast to the socialist ideal, were often apolitical single mothers at the margins of socialist society.

While Feinstein's argument was based on a review of Gegenwartsfilme throughout the entire GDR period, Rinke based her study solely on the portrayal of women in several key DEFA Frauenfilme made between 1972 and 1982. Yet both came to similar conclusions. This thesis followed the frameworks of Feinstein and Rinke in examining how women's sexual and material desires were regulated within the GDR and how this was depicted in Gegenwartsfilme from the fifties up to the early years of Honecker's rule. Similarly to the studies of Feinstein and Rinke, it has shown that the cinematic developments in portrayals of women's desires reflected the cultural trends in the GDR that led to an increased focus on the everyday and more critical portrayals of everyday life. But, unlike Feinstein and Rinke, by more closely grounding this study in the historical social changes affecting women's sexual and material desires, this thesis has shown that women were essential to the construction of alternate socialisms, and as such a dialogue opposed to the SED.

Chapter One argued that both women's sexual and material desires were regulated by the socialist personality and socialist morality during the fifties and sixties. These concepts were used by the SED to consolidate socialist control over East Germany 
by reconstructing the German identity to reflect the values of socialism against those of capitalism and National Socialism. The fifties and sixties were a period of sexual conservatism, where women's sexuality was confined to the spheres of marriage and motherhood. This conservatism was both reflected in Frauenschicksale, where sexual desires are portrayed as leading to subversion, degeneration and deviance when not tempered by socialist ideology, and in the critical responses of SED film officials to the depiction of nudity Dudow's film Verwirrung der Liebe. In terms of material desires, despite encouraging frugality, by virtue of the fact that the SED controlled access to material goods, women's material desires were not as strictly regulated as their sexual desires. Indeed, the SED used its control over goods to encourage Party loyalty, offering women extra ration cards for attending the first DFD conference (Harsch, 2007: 43). The use of extra ration cards to encourage women to become politically active also reflects the inherent gendering of consumption in the GDR. Women, through their roles as domestic provider, were associated with shopping and consumption in the post-war climate. This was also reflected in Frauenschicksale, where material desires are constructed as a feminine vice, Renate unable to control her desire for a new dress. As with her sexual desires, socialism was portrayed as the 'cure' for Renate's uncontrollable material urges.

The Kahlschlag of 1965, alongside the events of the Prague Spring in 1968, highlighted the "bankruptcy of socialism's utopian potential" provoking artists to reexamine life behind the Iron Curtain more critically (Feinstein, 2002: 6). This Utopieverlust is most aptly captured in Christa Wolf's novel Nachdenken über Christa $T$., where she examines the intersection of the socialist ideal of self-actualisation with 
reality. Wolf's text was fundamental to the developments that would occur in cinematic depictions of women. Firstly, her appropriation of the narrative voice, not only foreshadowed the trend towards subjectivity, but established a voice for women within East German society. Secondly, reflecting Wolf's writing style "subjective authenticity," Christa T is attempting to write "The Big Hope, or, The Difficulty of Saying 'I', , highlighting Christa T, and Christa Wolf's search for fulfillment and selfrealisation, both themes brought up in Der Dritte and Die Legende. Finally, Christa T's construction as an outsider pointed the way that portraits of women would move in East German film, which, as discussed above, would end with "misfits" like Susanne in Das Fahrrad. Most importantly, events like the Kahlschlag and Prague Spring, reframed relationships between artists and the East German state, with Nachdenken über Christa $T$. leading the way to more critical depictions of life under socialism.

The Prague Spring was also significant in setting the stage for the ideological and political developments that would be nurtured during the period of detente, in the early years of Honecker. Under Honecker, who replaced Ulbricht as SED leader in 1971, the concepts of the socialist personality and socialist morality were relaxed and, to a certain extent, replaced with an increased focus on the individual. These changes allowed women to sexually desire more freely, and as argued by Herzog, sex became a "crucial free space" for women (Herzog, 2005: 188). There was also a growth in Frauenpolitik and many policies were introduced that aimed at reconciling women's paid work with their domestic duties, leading SED politician Inge Lange to proclaim the realisation of gender equality in 1973 , quoted at the beginning of this thesis. Furthermore, there was an increased in the production of consumer goods and a state-wide housing project, both 
aimed at increasing individuals' wellbeing. Most importantly, the repressive period of the Kahlschlag came to an end with Honecker's pronouncement of "no taboos" in socialist artwork in 1971.

In spite of Lange's pronouncement, women's roles were to a certain extent still confined to the domestic sphere, a fact used by filmmaker's to code messages critical of the GDR. Despite legislating policies that encouraged women to reconcile motherhood with employment, no similar policies were introduced for fathers, serving to reinforce women's domestic roles. Seeing this, filmmakers instrumentalised female protagonists as symbols of greater societal discontent. In doing so, filmmakers relied on persisting gender norms that ensured women's voices would not be taken seriously. Interestingly, Christa Wolf also employed a similar encoding technique, splitting the narrative in both Nachdenken über Christa T. and her following novel Kindheitsmuster, to avoid censorship.

The final chapter of this thesis took the political and social developments discussed in Chapter Two and applied them in analysing two Gegenwartsfilme, Der Dritte and Die Legende. Firstly, both take advantage of Honecker's "no taboos" statement; indeed, while Der Dritte represents one of the earliest films to be produced in the era, Die Legende stood at the height of this period of cultural liberalisation. Furthermore, while the two films portray the relaxation of socialist morality and the increase of consumer goods as frameworks regulating women's desires, they do so in a critical fashion. Der Dritte questions Lange's pronouncement of gender equality by portraying Margit's confrontation with traditional gender norms that require her to play the role of coy mistress, leading her to exclaim "How undignified! The silly old games 
of grandma's day" (Günther, 1972). Although her sexual desires are no longer regulated by socialist morality, Margit must control her own sexual desires, or else be thought of negatively. Similarly, Paula's temptation of Paul in Die Legende illustrates that sexual desires that had the potential to remove an individual from the collective were still construed as subversive and beyond regulation. Furthermore, both films criticise material culture in the GDR as being used by the Party to replace more existential, nonmaterial forms of fulfillment, such as life and self-determination.

The last chapter also examined how the aesthetic developments made by Wolf in Nachdenken über Christa T. were reflected in the two films. Firstly, the films feature protagonists that reflect the movement towards "misfits," that started with the nonconformist Christa T. Although Margit is in many ways and ideal socialist heroine, her loneliness and questioning of the socialist regime set her apart. Paula, meanwhile, is much like Susanne from Das Fahrrad, a single mother who is poorly educated with a low paying job, and apolitical. Most importantly, similarly to Wolf's concern with the tension between the ideal and reality, both films use women's desires, be they sexual or material, as a vehicle to comment on the ability of GDR society to tolerate the protagonist's ideal. Furthermore, parallel to Christa T's difficulty in saying 'I,' the two protagonists, Margit and Paula, use their desires to obtain fulfillment. The struggles that the two women face in realising their desires are used to criticise socialism's failings. The difficulty Margit has in appropriating her own sexual agency and approaching Hrdlitschka is used to comment on the failure to create true gender equality. For Paula, however, her desires are too radical and too subversive to be tolerated by socialism. In focussing on the failure of socialist rhetoric and reality to meet ideals, both Günther and 
Carow are calling for a more pure form of socialism, based on the values of equality and love, as an alternative to the patriarchal SED style of socialism. Furthermore, they call for a 'domestication' of socialism, through an adoption of socialist ideals in the private sphere, in the areas of longing and desire. As these constructions of socialism are portrayed through the experiences of the female protagonist and set within the private domestic sphere, they are presented as inherently female forms of socialism.

Therefore alongside the 'domestication' of socialism presented in Der Dritte and Die Legende there was also a 'feminisation' of cinematic depictions of socialism. Whereas films in the fifties and sixties were used to instruct people on how they should desire under socialism, by the seventies films were used not to instruct, but to comment on how socialism controlled how people desired; instead of a top-down approach from the SED to the citizenry, the citizenry, a generation of which had grown up under socialism, were beginning to provide 'feedback' through cinema. This 'feedback' was not only constructed around depictions of a "recognizable quotidian" that viewers could identify with, but it was also centred on a woman's experience of socialism (Feinstein, 2002: 233). Women were pivotal in these cinematic shifts, because they were constructed as symbols of the potential of socialism and socialist development. As such, alongside the calls for a 'domestication' of socialism presented in both Der Dritte and Die Legende, the two films represent a growing 'feminisation' of socialism that would increase through the eighties (Baldez, 2003; Ferree, 1994; Funk and Müller, 1990). Rather than construct female protagonists as instruction manuals on the socialist ideal for women, female protagonists were instrumentalised to point to the failings of socialist 
ideal in reality, and to construct more humanist forms of socialism in opposition to the SED.

This 'feminisation' of socialism is not only important for understanding how artists engaged the viewer and the state, but also the role women played in creating a dialogue opposed to the SED when more open forms of dialogue were closed, and as such contributes to the differentiated approach to GDR history advocated by Jarausch and discussed in the introduction. In terms of the depiction of women's desires, the selfdetermination and passion that both Margit and Paula display in realising their desires, despite facing struggles, highlights that in spite of the repressive and authoritarian elements of state, women were empowered, evidenced in Christa Wolf's appropriation of her subjective voice. The question then becomes, how would this separate discourse of women's empowerment, quite different from the feminist discourses operating in West Germany, gain expression after 1989. Would it be yet another fault line of difference between the East and the West or would East German women be able to negotiate the new power structures and create a role for their subjective experiences in the new Germany? 


\section{Bibliography}

Allan, Seán. “DEFA: An Historical Overview.” Eds. Seán Allan and John Sanford. DEFA: East German Cinema, 1946-1992. New York: Berghahn Books, 1999: 1-21.

Baldez, Lisa. "Women's Movements and Democratic Transition in Chile, Brazil, East Germany, and Poland”. Comparative Politics. 35.3 (2003): 253-272.

Bebel, August. Woman Under Socialism. Trans. Daniel de Leon. New York: Schocken Books, 1971.

Becker, Franziska and Ina Merkel. "Das Ende der Utopie?" Ed. Franziska Becker, Ina Merkel and Simone Tippach-Schneider (eds). Das Kollektiv bin ich: Utopie und Alltag in der DDR. Vienna: Böhlau Verlag, 2000: 6-13.

Berghahn, Daniela. Hollywood Behind the Wall: The Cinema of East Germany. New York: Manchester University Press, 2005.

Biess, Frank. "'Pioneers of a New Germany': Returning POWs from the Soviet Union and the Making of East German Citizens, 1945-1950." Central European History. 32.2 (1999): 143-180.

Blunk, Harry. Die DDR in ihren Spielfilmen: Reproduktion und Konzeption der DDRGesellschaft im neuren DEFA-Gegenwartsspielfilm. Munich: Profil, 1984.

---."Medienanalyse: Der Dritte." Frauenbilder in den DDR-Medien. Bonn: Bundeszentrale für politische Bildung, 1997: 125-140.

Brecht, Bertolt. Journals, 1934-1955. Trans. Hugh Rorrison. Ed. John Willet. New York: Routledge, 1993.

Carow, Heiner. Die Legende von Paul und Paula. DEFA, 1973.

Dölling, Irene. "We all love Paula, but Paul is more important to us': Constructing a "Socialist Person" Using the "Femininity" of a Working Woman." New German Critique. 82 (2001): 77-90.

Dudow, Slatan. Frauenschicksale. DEFA, 1952.

---. Verwirrung der Liebe. DEFA, 1959.

---. "Zur Diskussion über den Film ,Frauenschicksale." Neues Deutschland. 21 November, 1952b: 4.

Eder, Klaus. "Wie zu Omas Zeiten.” Christ und Welt. 28 April, 1972. 
Egighian, Greg. "Homo Munitus: The East German Observed" Eds. Katherine Pence and Paul Betts. Socialist Modern: East German Everyday Culture and Politics. Ann Arbor: University of Michigan Press, 2008: 71-95.

---. "The Psychologization of the Socialist Self: East German Forensic Psychology and its Deviants, 1945-1975." German History. 22.2 (2004): 181-205.

"Egon Guenther." DEFA Film Library at the University of Massachusetts Amherst. $<$ http://defafilmlibrary.com/article info.php?cArticlePath=1\&articles id=28>.

Equal Opportunity for Women? A Report from the German Democratic Republic. Berlin:_Panorama DDR - Auslandspresseagentur, 1982.

Evans, Jennifer V. "Decriminalization, Seduction, and 'Unnatural Desire' in the German Democratic Republic" Feminist Studies special issue on Homosexuality and the (De)Regulation of Masculinity in Cold War Germany (forthcoming in Fall 2010).

---. "The Moral State: Men, Mining, and Masculinity in the Early GDR." German History. 23.3 (2005): 355-370.

Feinstein, Joshua. "Constructing the Mythic Present in the East German Cinema: Frank Beyer's 'Spur der Steine' and the $11^{\text {th }}$ Plenum of 1965." Central European History. 32.2 (1999): 203-220.

---. The Triumph of the Ordinary: Depictions of Daily Life in the East German Cinema, 1949-1989. Chapel Hill: University of Carolina Press, 2002.

Fenemore, Mark. "The Recent Historiography of Sexuality in Twentieth-Century Germany." The Historical Journal. 52.3 (2009): 763-779.

Ferree, Myra Marx. "The Time of Chaos Was the Best" Feminist Mobilization and Demobilization in East Germany." Gender and Society. 8.4 (1994): 597-623.

Frauenbilder in den DDR-Medien. Bonn: Bundeszentrale für politische Bildung, 1997.

Fries, Marilyn Sibley. "Christa Wolf's Use of Image and Vision in the Narrative Structuring of Experience" Ed. Margy Gerber et al. Studies in GDR Culture and Society 2: Selected Papers from the Eighth International Symposium on the German Democratic Republic. Lanham: University Press of America, 1982: 59-74.

"From the Series 'Zeitzeugensgespräche:' Author Günther Rücker About Her Third (2000)."Special Features. Günther, Egon. Der Dritte. DEFA, 1972.

Fulbrook, Mary. Interpretations of the Two Germanies, 1945-1990. $2^{\text {nd }}$ Ed. New York: St. Martin's Press, 2000. 
Funk, Nanette, Magda Müller, Robin Ostow, Michael Bodeman, and Matthias Weiss. "Dossier on Women in Eastern Europe". Social Text. 27 (1990): 88-122.

Gersch, Wolfgang. "Der Traum vom selbstbestimmten Menschen." Szenen eines Landes: Die DDR und ihre Filme. Berlin: Aufbau-Verlag, 2006. 138-151.

Grimm, Jacob. Teutonic Mythology: Volume IV. Trans. James Steven Stallybrass. London: George Bell and Sons, 1888.

Grossmann, Atina. "A Question of Silence: The Rape of German Women by Occupation Soldiers." October. 72 (1995): 42-63.

---. Jews, Germans and Allies: Close Encounters in Occupied Germany. Princeton: Princeton University Press, 2007.

Günther, Egon. Der Dritte. DEFA, 1972.

Harsch, Donna. "Approach/Avoidance: Communists and Women in East Germany, 1945-9." Social History. 25.2 (2000): 156-182.

---. "Footnote or Footprint? The German Democratic Republic in History. 23" Annual Lecture of the GHI, Washington DC, November 12, 2009." GHI Bulletin. 46 (2010): 925.

---. Revenge of the Domestic: Women, the Family, and Communism in the German Democratic Republic. New Jersey: Princeton University Press, 2007.

---. "Society, the State, and Abortion in East Germany, 1950-1972." The American Historical Review. 102.1 (1997): 53-84.

Haynes, John. "Brothers in Arms: The Changing Face of the Soviet Soldier in Stalinist Cinema." The Modern Language Review. 95.1 (2000): 154-167.

Heineman, Elizabeth D. What Difference Does a Husband Make? Women and Marital Status in Nazi and Postwar Germany. Los Angeles: University of California Press, 1999.

"Heiner Carow." DEFA Film Library at the University of Massachusetts Amherst. $<$ http://defafilmlibrary.com/article info.php?cArticlePath=1\&articles id=51 >.

Hell, Julia. Post-Fascist Fantasies: Psychoanalysis, History, and the Literature of East Germany. Durham: Duke University Press, 1997.

Helwig, Gisela. Frau und Familie: Bundesrepublik Deutschland-DDR. Cologne: Verlag Wissenschaft und Politik, 1987. 
Herf, Jeffrey. Divided Memory: The Nazi Past in the Two Germanys. Cambridge: Harvard University Press, 1997.

Herlinghaus, Hermann. "Heiner Carow: Filmkunst, die alle angeht - Ausgewähltes 70er Jahre - Eine Dokumentation." Aus Theorie und Praxis des Films. 3 (1983).

Herminghouse, Patricia. "Legal Equality and Women's Reality in the German Democratic Republic." Eds. Edith Hoshino Altbach, Jeanette Clausen, Dagmar Schultz and Naomi Stephan. German Feminism: Readings in Politics and Literature. Albany: State University of New York Press, 1984. 41-46.

Herzog, Dagmar. "East Germany's Sexual Evolution." Eds. Katherine Pence and Paul Betts. Socialist Modern: East German Everyday Culture and Politics. Ann Arbor: University of Michigan Press, 2008: 71-95.

---. Sex After Facism: Memory and Morality in Twentieth-Century Germany. Princeton: Princeton University Press, 2005.

Honecker, Erich. Report of the Central Committee to the Eighth Congress of the SED. Dresden: Verlag Zeit im Bild, 1972.

Hong, Young-Sun. "Cigarette Butts and the Building of Socialism in East Germany." Central European History. 35.3 (2002): 327-344.

Jarausch, Konrad H. Dictatorship as Experience: Towards a Socio-Cultural History of the GDR. New York: Berghahn Books, 1997.

Kater, Michael H. Different Drummers: Jazz in the Culture of Nazi Germany. New York: Oxford University Press, 1992.

Katzenstein, Alfred. "Male and Female in the German Democratic Republic." Ed. Georgene H. Seward and Robert C. Williamson. Sex Roles in Changing Society. New York: Random House, 1970: 240-256.

Kaufmann, Hans. "Subjective Authenticity: A Conversation with Hans Kaufmann.” Ed. Marilyn Sibley Fries. Responses to Christa Wolf: Critical Essays. Detroit: Wayne State University Press, 1989: 55-75.

Kersten, Heinz. "Die Rolle der Frau in DDR-Spielfilmen seit Anfang der siebziger Jahre." Frauenbilder in den DDR-Medien. Bonn: Bundeszentrale für politische Bildung, 1997: 9-19.

King James Bible. Ecc. 3: 1-5.

Kuby, Erich. The Russians and Berlin, 1945. Trans. Arnold J. Pomerans. London: Heinemann, 1965. 
Kuhn, Anna. Christa Wolf's Utopian Vision: From Marxism to Feminism. Cambridge: Cambridge University Press, 1988.

Lange, Inge. Die Frauen - active Mitgestalterinnen des Sozialismus. Ausgewählte Reden und Aufsätze. Berlin: Dietz Verlag, 1987.

Lewis, Alison. “'Foiling the Censor': Reading and Transference as Feminist Strategies in the Works of Christa Wolf, Irmtraud Morgner, and Christa Moog." The German Quarterly. 66.3 (1993): 372-386.

Lohmann, Ulrich. Ed. Aktuelle Dokumente, Herausgegeben von Professor Dr. Ingo Münch: Verfassung und Programm in der DDR. Berlin: de Gruyter, 1977.

Love, Myra N. Christa Wolf: Literature and the Conscience of History. New York: Peter Lang Publishing, 1991.

Marx, Karl and Friedrich Engels. Ed. S. Ryazanskaya. The German Ideology. Moscow: Progress Publishers, 1968.

Merfeld, Mechthild. Die Emanzipation der Frau in der Sozialistischen Theorie und Praxis. Reinbek bei Hamburg: Rowohlt Taschenbuch Verlag, 1972.

McCauley, Martin. The German Democratic Republic since 1945. New York: St. Martin's Press, 1983.

McLellan, Josie. "Visual Dangers and Delights: Nude Photography in East Germany." Past and Present. 205.1 (2009): 143-174.

Micheler, Stefan and Patricia Szobar. "Homophobic Propaganda and the Denunciation of Same-Sex-Desiring Men under National Socialism." Journal of the History of Sexuality. 11.1/2 (2002): $95-130$

Mosse, George L. The Image of Man: The Creation of Modern Masculinity. Oxford: Oxford University Press, 1999.

Mühlberg, Dietrich. “Alltag und Utopie: Gedanken bein einem Rückblick auf die Ostdeutsche Geschichte." Ed. Franziska Becker, Ina Merkel and Simone TippachSchneider. Das Kollektiv bin ich: Utopie und Alltag in der DDR. Vienna: Böhlau Verlag, 2000: 14-25.

Müller, Wenzel. Leben in der Platte: Alltagskultur der DDR der 70er und 80er Jahre. Vienna: Selbstverlag, 1999.

Naimark, Norman N. The Russians in Germany: A History of the Soviet Zone of Occupation, 1945-1949. Cambridge: Harvard University Press, 1995. 
Pence, Katherine. "Women on the Verge: Consumers Between Private Desires and Public Crisis." Eds. Katherine Pence and Paul Betts. Socialist Modern: East German Everday Culture and Politics. Ann Arbor: University of Michigan Press, 2008: 287-322.

Pflaum, Hans Günther. "Egon Günther: Bekenntnis zu Gefühlen." Film in der DDR. Munich: Carl Hanser Verlag, 1977.

Pieper, Ruidiger. "Official Policy and the Attitudes of GDR Youth towards Marriage and the Opposite Sex as Reflected in the Column 'Unter vier Augen." Margy Gerber et al. Studies in GDR Culture and Society 6: Selected Papers from the Eleventh New Hampshire Symposium on the German Democratic Republic. Lanham: University Press of America, 1986: 109-122.

Plenzdorf, Ulrich. Die Legende von Paul und Paula: Filmerzählung. Frankfurt am Main: Suhrkamp Taschenbuch Verlag: 1974.

Poiger, Ute. Jazz, Rock and Rebels: Cold War Politics and American Culture in a Divided Germany. Berkeley: University of California Press, 2000.

Poss, Ingrid and Peter Warnecke. Spur der Filme: Zeitzeugen über die DEFA. Berlin: DEFA Stiftung, 2006.

Rinke, Andrea. "From Models to Misfits: Women in DEFA Films of the 1970s and 1980s." Eds. Seán Allan and John Sanford. DEFA: East German Cinema, 1946-1992. New York: Berghahn Books, 1999: 183-203.

---. Images of Women in East German Cinema, 1972-1982. Lewiston: The Edwin Mellen Press, 2006.

---. "Models or Misfits? The Role of Screen Heroines in GDR Cinema." Eds. Ingeborg Majer-O'Sickey and Ingeborg von Zadow. Triangulated Visions: Women in Recent German Cinema. New York: State University of New York Press, 1998: 207-218.

---. "Sex and Subversion in German Democratic Republic cinema: 'The Legend of Paul and Paula' (1973)." Eds. Diana Holmes and Alison Smith. 100 Years of European Cinema: Entertainment or Ideology. Machester: Manchester University Press, 2000: 5263.

Romero, Christiane Zehl. "Vertreibung aus dem Paradies: Zur neuen Frauenliteratur in der DDR." Ed. Margy Gerber et al. Studies in GDR Culture and Society 3: Selected Papers from the Eighth International Symposium on the German Democratic Republic. Lanham: University Press of America, 1983: 71-86.

Rubin, Eli. "East German Plastics: Technology, Gender and Teleological Structures of Everyday Life." German History. 25.4 (2007): 596-624. 
---. "The Form of Socialism without Ornament: Consumption, Ideology, and the Fall and Rise of Modernist Design in the German Democratic Republic." Journal of Design History. 19.2 (2006): 155-168.

Rüß, Gisela. Dokumente zur Kunst-, Literatur- und Kulturpolitik der SED 1971-1974. Stuttgart: Seewald Verlag, 1976.

Sander, Helke and Renate Schlesier. "'Die Legende von Paul und Paula': Eine frauenveranchtend Schnulze aus der DDR." Frauen und Film. 2 (1974): 8-47.

Schenk, Ralf. Eine kleine Geschichte der DEFA: Daten, Dokumente, Erinnerungen. Berlin: DEFA-Stiftung, 2006.

Schmidt, Evelyn. Das Fahrrad. DEFA, 1981.

Shaffer, Harry G. Women in the Two Germanies: A Comparative Study of A Socialist and a Non-Socialist Society. New York: Pergamon Press, 1981.

---."The Status and Position of Women in the German Democratic Republic." Ed. Margy Gerber et al. Studies in GDR Culture and Society 3: Selected Papers from the Eighth International Symposium on the German Democratic Republic. Lanham: University Press of America, 1983: 57-70.

Stegmann, Vera. "'Frauenschicksale': A DEFA Film Viewed in Light of Brecht's Critique of the Opera and Eisler/Adorno's Theory of Film Music." German Studies Review. 28.3 (2005): 481-500.

Sieg, Katrin. "Sex, Subjectivity, and Socialism: Feminist Discourses in East Germany." Genders. 22 (1995): 105-133.

Ulbricht, Walter. "Aus dem Referat: Die sozialistische Umwälzung der Ideologie und der Kultur." Für den Sieg der sozialistischen Revolution auf dem Gebiet der Ideologie und der Kultur. Berlin: Dietz Verlag, 1958. 3-42.

Urang, John Griffith. "Realism and Romance in the East German Cinema, 1952-1962." Film History. 18 (2006): 88-103.

Wander, Maxie. Guten Morgen, du Schöne: Frauen in der DDR. Protokolle. Darmstadt: Luchterhand: 1978.

Wierling, Dorothee. "The Hitler Youth Generation in the GDR: Insecurities, Ambitions and Dilemmas" Ed. Konrad H. Jarausch. Dictatorship as Experience: Towards a SocioCultural History of the GDR. New York: Berghahn Books, 1999. 307-324. 
Wolf, Christa. Cassandra. Trans. Jan van Heurck. New York: Farrar, Straus and Giroux, 1984.

---. The Quest for Christa T. Trans. Christopher Middleton. New York: Farrar, Straus and Giroux, 1970. 